\title{
PENELITIAN SURVEI KEPUASAN MASYARAKAT TERHADAP PELAYANAN PERTANAHAN
}

DITERBITKAN OLEH:

PUSAT PENELITIAN DAN PENGEMBANGAN KEMENTERIAN AGRARIA DAN TATA RUANG/ BADAN PERTANAHAN NASIONAL 2018 


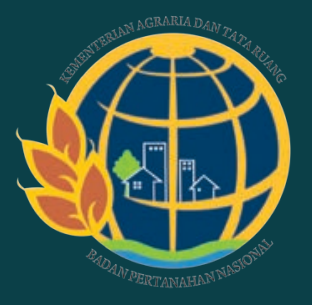

\section{LAPORAN AKHIR PENELITIAN}

SURVEI KEPUASAN MASYARAKAT TERHADAP PELAYANAN PERTANAHAN

PUSAT PENELITIAN DAN PENGEMBANGAN

Kementerian Agraria dan Tata Ruang/Badan Pertanahan Nasional

2018 


\section{PENELITIAN SURVEI KEPUASAN MASYARAKAT TERHADAP PELAYANAN PERTANAHAN}

\section{Diterbitkan Oleh:}

Pusat Penelitian dan Pengembangan

Kementerian Agraria dan Tata Ruang/Badan Pertanahan Nasional

Jl. Akses Tol Cimanggis, Cikeas Udik, Gunung Putri, Kabupaten Bogor, Jawa Barat 16966

Cetakan Pertama - Desember 2018

ISBN: 978-979-1069-66-3

Hak Cipta dilindungi oleh Undang-Undang.

Dilarang mengutip atau memperbanyak sebagian atau seluruh

isi buku ini tanpa izin tertulis dari Pemegang Hak Cipta.

\section{TIM PENYUSUN}

1. Koordinator : Trie Sakti, S.H., CN., M.H.

2. Pembantu Peneliti : Ir. Eliana Sidipurwanty, M.Si.

Septina Marryanti Prihatin, S.Si., M.Si.

Romi Nugroho, S.Si.

Arditya Wicaksono, S.IP.

Eri Khaeruman Khuluki, S.P., M.Si.

Ambar Nur Hadi, S.T., M.P.P., M.Eng.

Arsan Nurrokhman, S.Si. 


\section{KATA PENGANTAR}

Dalam rangka peningkatan kualitas pelayanan publik sebagai perwujudan dari fungsi aparatur negara sebagai abdi masyarakat, maka dilakukan Survei Kepuasan Masyarakat oleh Pusat Penelitian dan Pengembangan Kementerian Agraria dan Tata Ruang/Badan Pertanahan Nasional sebagai tolak ukur keberhasilan penyelenggaraan pelayanan. Survei juga dilakukan untuk mengetahui kinerja pelayanan Kantor Pertanahan kepada masyarakat secara berkala sebagai bahan evaluasi untuk menetapkan kebijakan dalam rangka peningkatan kualitas pelayanan pertanahan selanjutnya dan masyarakat dapat mengetahui kinerja pelayanan Kantor Pertanahan yang bersangkutan.

Hasil Survei Kepuasan Masyarakat diharapkan dapat menjadi motivasi dalam peningkatan kualitas pelayanan publik Kantor Pertanahan untuk mewujudkan akuntabilitas kinerja dan meningkatkan kepercayaan masyarakat terhadap Kantor Pertanahan. Terhadap unsur pelayanan yang dipersepsikan lemah oleh responden pengguna layanan Kantor Pertanahan diharapkan dapat diprioritaskan tindak lanjut perbaikannya.

Terima kasih kepada semua pihak yang telah memberikan dukungan atas terlaksananya Survei Kepuasan Masyarakat Tahun 2018. Semoga dapat bermanfaat untuk memperbaiki pelayanan pertanahan di masa mendatang.

Jakarta, Desember 2018

Kepala Pusat Penelitian dan Pengembangan 


\section{DAFTAR ISI}

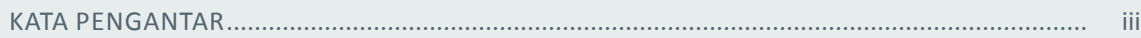

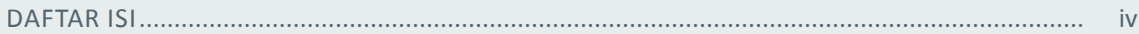

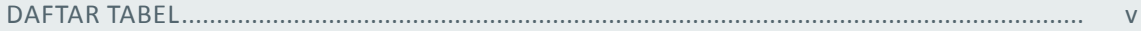

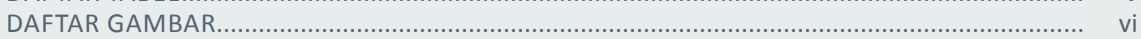

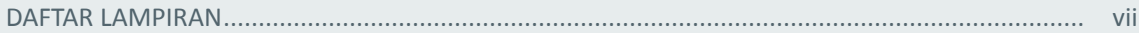

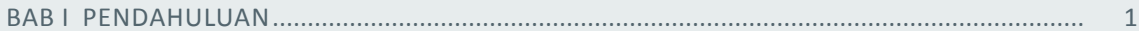

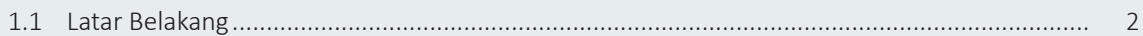

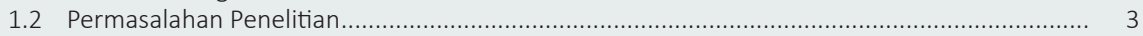

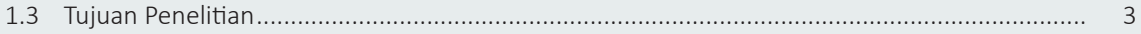

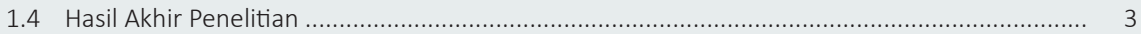

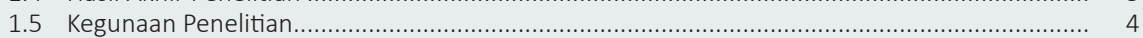

1.6 Ruang Lingkup Penelitian ............................................................................................. 4

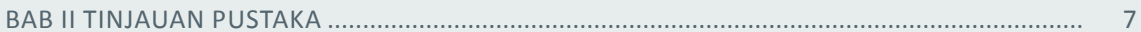

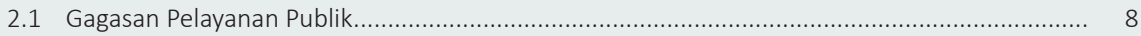

2.2 Pelayanan Publik .................................................................................................................. 8

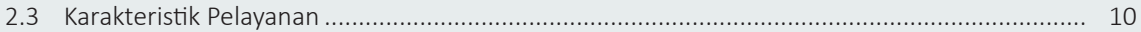

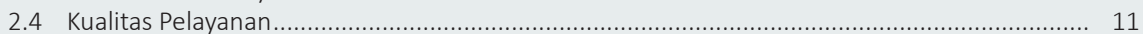

2.5 Konsep Ideal Pelayanan Publik di Indonesia ........................................................................ 14

2.6 Kantor Pertanahan Penentu Keberhasilan Pelayanan Pertanahan Berkualitas ...................... 16

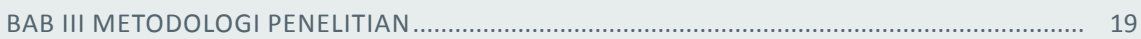

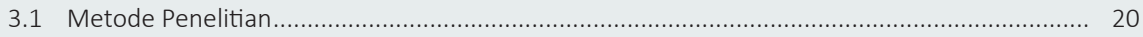

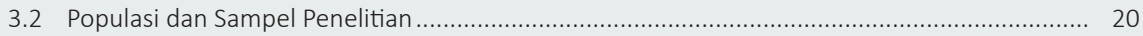

3.3 Teknik Pengumpulan Data Penelitian ................................................................................... 22

3.4 Teknik Pengolahan dan Analisis Data .................................................................................... 22

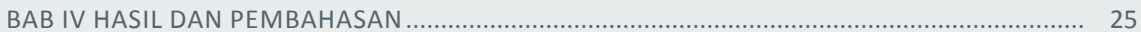

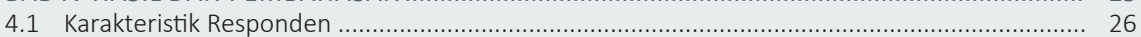

4.2 Pengukuran Survei Kepuasan Masyarakat (SKM) ............................................................ 30

4.3 Penilaian Masyarakat Terhadap Pelayanan Kantor Pertanahan (Indepth Interview) ................ 51

4.4 Observasi Kantor Pertanahan .................................................................................... 58

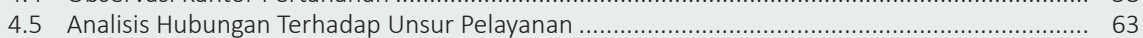

4.6 Rencana Tindak Lanjut Perbaikan SKM ................................................................. 68

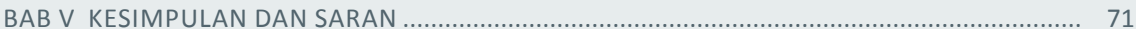

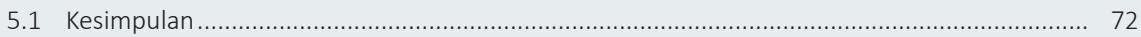

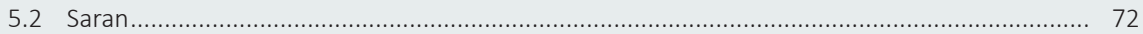

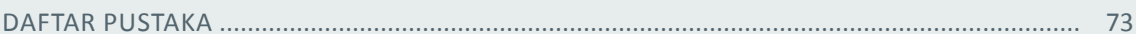

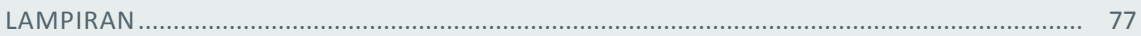

\section{Pusat Penelitian dan Pengembangan} Kementerian Agraria dan Tata Ruang/Badan Pertanahan Nasional 


\section{DAFTAR TABEL}

Tabel 2.1 Dimensi-Dimensi Pelayanan yang Berkualitas .................................................... 14

Tabel 3.1 Interval Nilai Survei Kepuasan Masyarakat ............................................................. 23

Tabel 3.2 Unsur (Ruang Lingkup) Pelayanan.................................................................... 23

Tabel 4.1 Hasil Analisis Korelasi Antar Unsur Pelayanan di Lokasi Sampel ................................. 64

Tabel 4.2 Penilaian Unsur Pelayanan ................................................................................ 67

Tabel 4.3 Solusi Untuk Perbaikan Unsur Pelayanan............................................................... 68

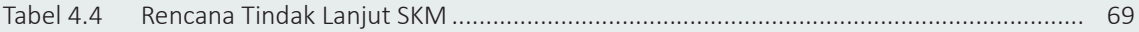




\section{DAFTAR GAMBAR}

Gambar 4.1 Karakter Responden Menurut Umur ..................................................................... 26

Gambar 4.2 Karakter Responden Berdasarkan Jenis Kelamin ............................................. 27

Gambar 4.3 Karakteristik Responden Berdasarkan Jenis Kelamin di Masing-masing Kantor

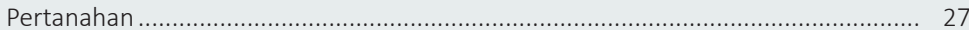

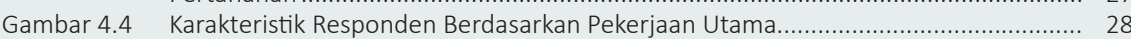

Gambar 4.5 Karakteristik Responden Berdasarkan Pendidikan .................................................. 29

Gambar 4.6 Karakteristik Responden Berdasarkan Jenis Layanan ........................................ 29

Gambar 4.7 Karakteristik Responden Berdasarkan Status Pemohon ......................................... 30

Gambar $4.8 \quad$ Nilai SKM Menurut Provinsi ............................................................................... 31

Gambar 4.9 Nilai SKM Menurut Kabupaten/Kota................................................................ 32

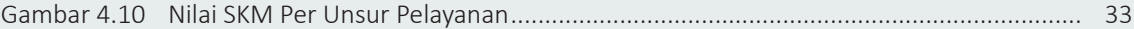

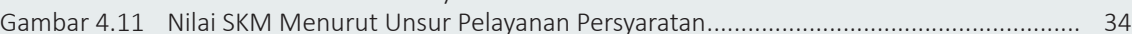

Gambar 4.12 Nilai SKM Menurut Unsur Prosedur .................................................................... 35

Gambar 4.13 Nilai SKM Menurut Unsur Waktu Pelayanan ...................................................... 36

Gambar 4.14 Nilai SKM Menurut Unsur Biaya/Tarif ............................................................... 37

Gambar 4.15 Nilai SKM Menurut Unsur Produk Spesifikasi Jenis Pelayanan.................................. 38

Gambar 4.16 Nilai SKM Menurut Unsur Kompetensi Pelaksana............................................. 39

Gambar 4.17 Nilai SKM Menurut Unsur Pelayanan Perilaku Pelaksana...................................... 40

Gambar 4.18 Nilai SKM Menurut Unsur Sarana dan Prasarana ...................................................... 41

Gambar 4.19 Nilai SKM Menurut Unsur Penanganan Pengaduan, Saran, dan Masukan............... 42

Gambar 4.20 Nilai SKM Menurut Jenis Pelayanan.................................................................... 42

Gambar 4.21 Nilai SKM Menurut Jenis Pelayanan Pendaftaran Tanah Pertama Kali..................... 43

Gambar 4.22 Nilai SKM Menurut Jenis Pelayanan Peralihan Hak .................................................. 44

Gambar 4.23 Nilai SKM Menurut Jenis Pelayanan Pengecekan ............................................. 45

Gambar 4.24 Nilai SKM Menurut Jenis Pelayanan Roya..................................................... 46

Gambar 4.25 Nilai SKM menurut Jenis Pelayanan PTSL ............................................................. 47

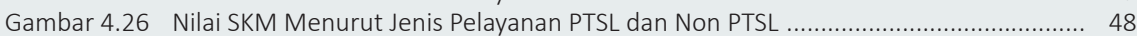

Gambar 4.27 Perbandingan Nilai SKM PTSL dan Non PTSL Berdasarkan Unsur Pelayanan ............ 49

Gambar 4.28 Nilai SKM Berdasarkan Subyek Pemohon ..................................................... 50

Gambar 4.29 Nilai SKM Menurut Wilayah Pulau Jawa dan Luar Pulau Jawa ................................. 51

Gambar 4.30 Persentase Hasil Indept Interview Penilaian Masyarakat Terhadap Aspek

Persyaratan dan Prosedur Pelayanan ................................................................. 53

Gambar 4.31 Persentase Hasil Indept Interview Penilaian Masyarakat Terhadap Aspek Waktu Pelayanan dan Biaya/Tarif ................................................................................... 54

Gambar 4.32 Persentase Hasil Indept Interview Penilaian Masyarakat Terhadap Aspek Penanganan Pengaduan, Saran dan masukan, Kejelasan Petugas/Pelaksana dan Kompetensi Pelaksana

Gambar 4.33 Persentase Hasil Indept Interview Penilaian Masyarakat Terhadap Aspek Perilaku Pelaksana Dan Maklumat Pelayanan ........................................................... 56

Gambar 4.34 Persentase Hasil Indept Interview Penilaian Masyarakat Terhadap Aspek Kemanan, Kenyamanan dan Komitmen Penyelenggara Pelayanan Publik ................................ 57

Gambar 4.35 Grafik Nilai Obeservasi Kantor Pertanahan per Kabupaten/Kota........................... 58

Gambar 4.36 Kondisi Loket Pelayanan ................................................................................. 59

Gambar 4.37 Kualitas Petugas Loket Pelayanan ....................................................................... 60

Gambar 4.38 Kondisi Sarana dan Prasarana Layanan Pertanahan ............................................... 61

Gambar 4.39 Peningkatan Prosedur Pelayanan ........................................................................ 63 


\section{DAFTAR LAMPIRAN}

Lampiran 1 Kuesioner Survei Kepuasan Masyarakat.....

Lampiran 2

Kriteria Responden dan Penjelasan Kuesioner Survei Kepuasan Masyarakat.

79

Lampiran 3

Panduan Pelaksanan Indepth Interview

80

Lampiran 4

Panduan Observasi Kondisi Kantor

83

Lampiran 5

Dokumentasi Pelayanan di Lokasi Sampel

85 



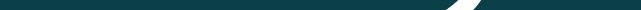




\subsection{Latar Belakang}

Kementerian Agraria dan Tata Ruang/Badan Pertanahan Nasional yang merupakan lembaga pemerintah dengan basis pelayanan tidak dapat dilepaskan dari adanya upaya memberikan pelayanan terbaik bagi masyarakat. Hal ini sejalan dengan tujuan Undang-undang Nomor 25 tahun 2009 tentang pelayanan publik yaitu untuk memberikan kepastian hukum dalam hubungan antara masyarakat dan penyelenggara dalam pelayanan publik. Pelayanan tidak dapat dipisahkan dari masyarakat karena masyarakat membutuhkan pelayanan publik yang berkualitas dari pemerintah. Kualitas pelayanan merupakan perbandingan antara kenyataan atas pelayanan yang diterima dengan harapan atas pelayanan yang ingin diterima.

Dalam mengevaluasi kualitas pelayanan tidak hanya ditentukan oleh pemerintah saja namun juga ditentukan oleh masyarakat, hal ini seperti yang dijelaskan bahwa berbicara mengenai kualitas pelayanan, ukurannya bukan hanya ditentukan oleh pihak yang melayani saja tapi lebih banyak dilayani, karena merekalah yang menikmati layanan sehingga dapat mengukur kualitas pelayanan berdasarkan harapan-harapan mereka dalam memenuhi kepuasannya. Karena dalam pelayanan publik, kepuasan masyarakat merupakan faktor penentu kualitas, maka setiap organisasi penyedia layanan publik diharapkan mampu memberikan kepuasan kepada pelanggannya. ${ }^{1}$

Penyelenggaraan pelayanan publik dalam beberapa sektor pelayanan dianggap masih rendah, termasuk Kementerian Agraria dan Tata Ruang/Badan Pertanahan Nasional. Hal ini dibuktikan dengan masih banyaknya pengaduan dan keluhan dari masyarakat baik melalui media cetak, media visual, media sosial maupun laporan ke Kantor Pertanahan/Kantor Wilayah dan Inspektorat Jenderal.

Dalam upaya untuk meningkatkan pelayanan publik maka Kementerian Agraria dan Tata Ruang telah melakukan berbagai upaya peningkatan pelayanan dengan perbaikan kinerja pelayanan, penyempurnaan standar pelayanan dan menciptakan inovasi pelayanan. Hal ini penting dilakukan karena masih adanya paradigma dalam masyarakat bahwa pelayanan pertanahan cenderung rumit, lama prosesnya, kurang transparan dan biayanya mahal.

Berkaitan dengan peningkatan pelayanan publik, Pemerintah Pusat mengamanatkan kepada seluruh institusi pemerintahan, baik di tingkat pusat maupun daerah, untuk melakukan Survei Kepuasan Masyarakat sebagai tolak ukur keberhasilan penyelenggaraan pelayanan. Sebagai tindak lanjut amanat tersebut, Kementerian Pendayagunaan Aparatur Negara dan Reformasi Birokrasi telah menetapkan Peraturan Menteri Pendayagunaan Aparatur Negara dan Reformasi Birokrasi Nomor 14 Tahun 2017 tentang Pedoman Penyusunan Survei Kepuasan Masyarakat Unit Penyelenggara Pelayanan Publik, yang menggantikan Peraturan Menteri Pendayagunaan Aparatur Negara dan Reformasi Birokrasi Nomor 16 Tahun 2014 tentang Pedoman Survei Kepuasan Masyarakat terhadap Penyelenggaraan Pelayanan Publik. Peraturan Menteri Pendayagunaan Aparatur Negara dan Reformasi Birokrasi tersebut menjadi acuan bagi pemerintah pusat dan daerah untuk mengevaluasi penyelanggaraan pelayanan publik sekaligus sebagai alat untuk meningkatkan kinerja pelayanan publik.

1 Barata, Atep, Adya, 2003, Dasar-Dasar Pelayanan Prima, PT. Elexmedia Computindo: Jakarta 
Berdasarkan beberapa pengukuran yang sudah dilakukan terhadap kualitas pelayanan pertanahan (BPN) diperoleh gambaran sebagai berikut:

1. Hasil Survei Integritas Sektor Publik Indonesia Tahun 2014 yang dilaksanakan oleh KPK menyajikan data bahwa BPN dalam pelayanan Hak Atas Tanah memperoleh nilai integritas total 6,14 sedangkan pada pelayanan Penghapusan Hak Tanggungan (Roya) memiliki nilai integritas total 7,42 . Rata-rata total nilai integritas untuk seluruh lembaga yang telah disurvei berada pada angka 7,22;

2. Hasil Survei Penilaian Integritas Tahun 2017 yang dilaksanakan oleh KPK dilakukan terhadap 6 kementerian/lembaga, 15 pemerintah provinsi, 15 pemerintah kabupaten/ kota menyajikan data bahwa Kementerian Agraria dan tata Ruang/BPN memperoleh skor 69,12 .

3. Hasil penelitian Puslitbang Kementerian Agraria dan Tata Ruang/Badan Pertanahan Nasional Tahun 2014 tentang Indeks Kepuasan Masyarakat dengan jumlah responden sebanyak 3.881 orang (28 Kabupaten/Kota pada 14 Provinsi) diperoleh angka 70,61.

4. Hasil penelitian Puslitbang Kementerian Agraria dan Tata Ruang/Badan Pertanahan Nasional Tahun 2016 tentang Survei Kepuasan Masyarakat dengan jumlah responden sebanyak 4.729 orang (34 Kabupaten/Kota pada 17 Provinsi) diperoleh angka 72,84.

5. Hasil penelitian Puslitbang Kementerian Agraria dan Tata Ruang/Badan Pertanahan Nasional Tahun 2017 tentang Survei kepuasan Masyarakat dengan jumlah responden 2.662 orang (28 Kabupaten/Kota pada 14 Provinsi) diperoleh angka 72,47.

Hasil pengukuran tingkat kepuasan masyarakat terhadap pelayanan pertanahan dapat dijadikan sebagai ukuran untuk terus memperbaiki kualitas pelayanan, sedangkan untuk memperoleh gambaran tingkat kepuasan tersebut patut dilakukan secara kontinyu serta dalam cakupan yang lebih luas mengingat pelayanan pertanahan berada diseluruh wilayah NKRI sehingga benar-benar dapat menjadi bahan evaluasi karena merepresentasikan kondisi sebenarnya di lapangan.

\subsection{Permasalahan Penelitian}

Adapun permasalahan penelitian dalam penelitian Survei Kepuasan Masyarakat (SKM) Terhadap Pelayanan Pertanahan yang nantinya perlu dijawab adalah "bagaimana tingkat kepuasan masyarakat terhadap pelayanan pertanahan di Kantor Pertanahan Kabupaten/Kota sampel"?

\subsection{Tujuan Penelitian}

Tujuan dilaksanakannya kegiatan penelitian Survei Kepuasan Masyarakat (SKM) Terhadap Pelayanan Pertanahan adalah: Mengetahui tingkat kepuasan masyarakat terhadap pelayanan pertanahan di Kantor Pertanahan Kabupaten/Kota sampel.

\subsection{Hasil Akhir Penelitian}

Adapun hasil akhir yang diharapkan dari pelaksanaan penelitian ini antara lain berupa: Analisis tingkat kepuasan masyarakat terhadap pelayanan pertanahan di Kantor Pertanahan Kabupaten/Kota sampel. 


\subsection{Kegunaan Penelitian}

Kegunaan penelitian Survei Kepuasan Masyarakat Terhadap Pelayanan Pertanahan antara lain:

1. Diketahuinya kelemahan dan kekuatan pada unsur yang dimiliki oleh penyelenggara layanan pertanahan (Kantor Pertanahan);

2. Diketahui kinerja penyelenggaraan pelayanan pertanahan yang telah dilaksanakan oleh Kantor Pertanahan secara periodik;

3. Sebagai bahan informasi bagi lembaga dalam menyusun kebijakan guna meningkatkan kualitas pelayanan dan perbaikan kondisi Kantor Pertanahan sehingga mampu berkorelasi positif terhadap kepuasan masyarakat dalam mengakses layanan pertanahan.

\subsection{Ruang Lingkup Penelitian}

\subsubsection{Ruang Lingkup Materi}

Penelitian ini difokuskan pada tingkat kepuasan masyarakat dan kondisi Kantor Pertanahan dalam mendukung pelayanan. Adapun Survei Kepuasan Masyarakat dilaksanakan sesuai dengan Peraturan Menteri Pendayagunaan Aparatur Negara dan Reformasi Birokrasi Nomor 14 Tahun 2017, yang meliputi unsur:

1. Persyaratan

Persyaratan adalah syarat yang harus dipenuhi dalam pengurusan suatu jenis pelayanan, baik persyaratan teknis maupun administratif.

2. Sistem, Mekanisme dan Prosedur

Prosedur adalah tata cara pelayanan yang dibakukan bagi pemberi dan penerima pelayanan, termasuk pengaduan.

3. Waktu Penyelesaian

Waktu penyelesaian adalah jangka waktu yang diperlukan untuk menyelesaikan seluruh proses pelayanan dari setiap jenis pelayanan.

4. Biaya/Tarif

Biaya/Tarif adalah ongkos yang dikenakan kepada penerima layanan dalam mengurus dan/ atau memperoleh pelayanan dari penyelenggara yang besarnya ditetapkan berdasarkan kesepakatan antara penyelenggara dan masyarakat.

5. Produk Spesifikasi Jenis Pelayanan

Produk spesifikasi jenis pelayanan adalah hasil pelayanan yang diberikan dan diterima sesuai dengan ketentuan yang telah ditetapkan. Produk pelayanan ini merupakan hasil dari setiap spesifikasi jenis pelayanan.

6. Kompetensi Pelaksana

Kompetensi Pelaksana adalah kemampuan yang harus dimiliki oleh pelaksana meliputi pengetahuan, keahlian, keterampilan, dan pengalaman.

7. Perilaku Pelaksana

Perilaku Pelaksana adalah sikap petugas dalam memberikan pelayanan.

\section{Pusat Penelitian dan Pengembangan}


8. Penanganan Pengaduan, Saran dan Masukan

Penanganan pengaduan, saran dan masukan adalah tata cara pelaksanaan pengaduan dan tindak lanjut

\section{Sarana dan Prasarana}

Sarana, adalah segala sesuatu yang dapat dipakai sebagai alat dalam mencapai maksud dan tujuan. Prasarana adalah segala sesuatu yang merupakan penunjang utama terselenggaranya suatu proses (usaha, pembangunan, proyek). Sarana digunakan untuk benda yang bergerak (komputer, mesin), dan prasarana untuk benda yang tidak bergerak.

Selain itu untuk mengetahui kondisi Kantor Pertanahan dalam mendukung pelayanan khususnya pada bagian loket dapat melihat pada fasilitas maupun kualitas loket yang ada (Peraturan Kepala BPN No. 3 Tahun 2010 tentang Loket Pelayanan Pertanahan). Kualitas Loket pelayanan merupakan salah satu tolok ukur kinerja Kantor Pertanahan dalam melayani masyarakat.

Peningkatan kualitas loket pelayanan dilakukan berdasarkan amanat Undang-undang nomor 25 tahun 2009 tentang Pelayanan Publik yang menyatakan bahwa penyelenggara pelayanan publik berkewajiban antara lain menempatkan pelaksana yang kompeten, menyediakan sarana, prasarana dan/atau fasilitas pelayanan publik yang mendukung terciptanya iklim pelayanan yang memadai, memberikan pelayanan yang berkualitas sesuai asas penyelenggaraan pelayanan publik, memberikan pertanggungjawaban terhadap pelayanan yang diselenggarakan dan membantu masyarakat dalam memahami hak dan tanggung jawabnya.

Melihat dari sisi fasilitas loket pelayanan maka akan tertuju pada fasilitas fisik, seperti meja loket, ruang tunggu, papan/panel informasi hingga nomor antrian. Sedangkan apabila melihat dari sisi kualitas loket, bisa dari sisi kualitas petugas loket, sarana dan prasarana, serta peningkatan prosedur.

\subsubsection{Ruang Lingkup Lokasi Penelitian}

Lokasi penelitian merupakan Kantor Pertanahan Kabupaten/Kota yang menjadi sampel penelitian.

\subsubsection{Ruang Lingkup Responden}

Responden merupakan masyarakat yang pernah mendapatkan layanan pertanahan baik masyarakat langsung (termasuk penerima sertipikat dari PTSL) maupun kuasa di Kantor Pertanahan Kabupaten/Kota setempat. 



\subsection{Gagasan Pelayanan Publik}

Gagasan mengenai pelayanan publik semakin mengemuka ditandai oleh berkembangnya forum ilmiah tentang pelayanan publik. Kondisi ini terlihat jelas mulai akhir tahun 1980-an di mana administrasi negara yang dikenal sebagai sebuah ilmu tidak lagi membahas bagaimana administrasi kantor pemerintah semata melainkan sudah pada tataran multidimensi. Kajian mutakhir seorang ilmuwan administrasi harus mampu untuk mengelola, menata, dan merancang sebuah sistem organisasi pemerintah. Organisasi pemerintah sebagai core dari kajian ilmuwan administrasi sudah selayaknya mengetahui bagaimana merancang sebuah kebijakan yang memiliki visi jelas untuk memperbaiki mutu pelayanan publik. Sebagai seorang pelayan publik kondisi riil tidak saja menghadirkan seorang administrator untuk merespon tuntutan masyarakat, sejalan dengan itu juga dihadapkan pada persoalan kepentingan.

Pelayanan publik dalam perkembangannya mengalami sebuah kajian yang sangat komprehensif. Kebutuhan penyediaan layanan juga semakin berkembang sehingga memerlukan telaah secara seksama dan berkesinambungan agar mudah memenuhi kebutuhan akan sebuah layanan yang dilakukan organisasi pemerintah kepada masyarakat, baik pelayanan yang sifatnya public good atau public regulator. Pelayanan publik pada hakikatnya adalah amanah Undang-Undang Nomor 25 Tahun 2009 tentang pelayanan publik, di mana definisi mengenai pelayanan publik adalah kegiatan atau rangkaian kegiatan dalam rangka pemenuhan kebutuhan pelayanan sesuai dengan peraturan perundang-undangan bagi setiap warga negara dan penduduk atas barang, jasa, dan/atau pelayanan administratif yang disediakan oleh penyelenggara pelayanan publik ${ }^{2}$. Berdasarkan penjelasan tersebut dapat ditarik sebuah benang merah bahwa pelayanan publik merupakan sebuah output dari apa yang dipikirkan, dilakukan, dan dikerjakan oleh organisasi pemerintah, dalam arti sederhana peraturan tersebut ada dan dibuat untuk melayani kebutuhan masyarakat.

\subsection{Pelayanan Publik}

Sejak dimulainya era reformasi tuntutan untuk perbaikan pelayanan publik di Indonesia semakin gencar dilakukan. Buruknya pelayanan publik selama ini menjadi salah satu variabel penting yang mendorong munculnya krisis kepercayaan masyarakat kepada pemerintah. Oleh karena itu perbaikan pelayanan publik mutlak diperlukan agar image buruk masyarakat kepada pemerintah dapat diperbaiki, karena dengan perbaikan kualitas pelayanan publik yang semakin baik dapat mempengaruhi kepuasan masyarakat terhadap pemerintah.

Terkait dengan pelayanan publik, Presiden RI Joko Widodo berpesan untuk semua pelayanan publik terintegrasi, cepat, dan transparan, agar bisa menekan praktik suap dan korupsi. Hal itu diungkapkan saat membuka rangkaian acara Hari Anti Korupsi Sedunia (Hakordia), di Hotel Bidakara, Jakarta. Presiden menyebut, sistem pelayanan publik seperti itu, harus dijadikan model nasional. "Sistem pelayanan publik, jika sederhana, cepat dan transparan, tidak ada relevansinya untuk menyuap. Yang menyuap itu pasti yang ribet, bertele-tele, dan tidak transparan," ujar Jokowi, di hadapan para pimpinan Komisi Pemberantasan Korupsi (KPK), sejumlah menteri, dan ketua partai politik yang hadir dalam pembukaan Hakordia 2018.

2 Lihat dalam Undang- Undang Nomor 25 Tahun 2009 tentang Pelayanan Publik ketentuan umum Pasal 1ayat 1. 
Berkaitan dengan pelayanan publik ini, dikenal beberapa pandangan antara lain yang berkembang di Amerika Serikat dengan munculnya paradigma post-bureaucratic oleh Barzelay (1992) bersama dengan Armajani (1997). Pandangan post-bureacratic berkaitan dengan pelayanan publik terlihat pada penekanan administrasi publik pada hasil yang berguna bagi masyarakat, kualitas dan nilai, produk dan keterikatan terhadap norma, dan mengutamakan misi, pelayanan dan hasil akhir (outcome). Kemudian selanjutnya dalam waktu yang hampir bersamaan muncul pula paradigma reinventing government yang disampaikan oleh Osborne dan Gaebler (Keban, 2008), dioperasionalisasikan oleh Osborne dan Plastrik pada tahun 1997 dalam karyanya Banishing Bureaucracy: The Five Strategies for Reinventing Government. Paradigma ini juga dikenal dengan nama New Public Management. Pandangan dari paradigma ini sebenarnya menekankan bahwa pemerintah atau birokrat sesungguhnya haruslah memberikan pelayanan terbaiknya kepada masyarakat. Mereka menilai bahwa pemerintahan harus mengalihkan wewenang kontrol yang dimilikinya kepada masyarakat. Masyarakat diberdayakan sehingga mampu mengontrol pelayanan yang diberikan oleh pemerintah. New Public Management dipandang sebagai pendekatan dalam administrasi publik yang menerapkan pengetahuan dan pengalaman yang diperoleh dalam dunia manajemen bisnis dan disiplin yang lain untuk memperbaiki efisiensi, efektivitas, dan kinerja pelayanan publik pada birokrasi moderen (Vigoda, dalam Keban, 2008). ${ }^{3}$

Selanjutnya Janet V Denhardt dan Robert V Denhardt dalam bukunya New Public Services menyatakan bahwa pelayanan publik tidak boleh dijalankan seperti sebuah bisnis, pelayanan publik harus senantiasa memperhatikan dan berfokus kepada ke pentingan warga negara (masyarakat) yang tidak hanya sebatas kepada pelanggan. Hal ini seakan berbanding terbalik dengan kondisi dan situasi pelayanan publik di Negara Kesatuan Republik Indonesia (NKRI) yang kecenderungan masih berfokus kepada pelanggan, dimana persepsi tentang pelanggan adalah siapa yang berani membayar lebih maka pelayanan akan diutamakan (baca biaya pelayanan publik) baik itu pelayanan yang bersifat administratif (surat menyurat), barang (proyek) serta jasa (penentuan kebijakan).

Di Indonesia pelayanan publik diatur dalam Undang-Undang Nomor 25 Tahun 2009 Tentang Pelayanan Publik, pelayanan publik didefinisikan sebagai kegiatan atau rangkaian kegiatan dalam rangka pemenuhan kebutuhan pelayanan sesuai dengan peraturan perundangundangan bagi setiap warga negara dan penduduk atas barang, jasa, dan/atau pelayanan administratif yang disediakan oleh penyelenggara pelayanan publik. Pelayanan publik juga dipahami sebagai suatu kegiatan yang dilakukan oleh seseorang atau sekelompok orang dengan landasan faktor materiil melalui sistem, prosedur, dan metode tertentu dalam rangka usaha memenuhi kepentingan orang lain sesuai dengan haknya sebagai warga negara. Berkaitan dengan hak-hak yang melekat pada publik, pelayanan publik adalah pengertian yang ditujukan kepada suatu pelayanan terhadap kebutuhan masyarakat yang bersifat umum sehingga hendaknya dapat dilaksanakan dengan sebaik-baiknya.

Penilaian terhadap pelayanan publik menyangkut segala aspek mencakup sistem, prosedur dan metode dalam memenuhi hak-hak publik, baik sebagai penyelenggara maupun pengguna pelayanan publik. Kualitas pelayanan publik dikatakan baik jika penyelenggara pelayanan publik dapat memberikan pelayanan sesuai dengan regulasi yang berlaku dan kebutuhan masyarakat sebagai pengguna pelayanan publik sehingga tercipta kepuasan masyarakat

3 Abdul Mahsyar, Masalah Pelayanan Publik di Indonesia Dalam Perspektif Administrasi Publik, Oktober,2011 
terhadap penyelenggaraan pelayanan publik. Penyelenggara pelayanan publik sebagaimana termaktub dalam Pasal 34 Undang undang No 25 tahun 2009 tentang Pelayanan Publik harus berperilaku sebagai berikut:

1. adil dan tidak diskriminatif;

2. cermat;

3. santun dan ramah;

4. tegas, andal, dan tidak memberikan putusan yang berlarut-larut;

5. profesional;

6. tidak mempersulit;

7. patuh pada perintah atasan yang sah dan wajar;

8. menjunjung tinggi nilai-nilai akuntabilitas dan integritas institusi penyelenggara;

9. tidak membocorkan informasi atau dokumen yang wajib dirahasiakan sesuai dengan peraturan perundang-undangan;

10. terbuka dan mengambil langkah yang tepat untuk menghindari benturan kepentingan;

11. tidak menyalahgunakan sarana dan prasarana serta fasilitas pelayanan publik;

12. tidak memberikan informasi yang salah atau menyesatkan dalam menanggapi permintaan informasi serta proaktif dalam memenuhi kepentingan masyarakat;

13. tidak menyalahgunakan informasi, jabatan, dan/atau kewenangan yang dimiliki;

14. sesuai dengan kepantasan; dan

15. tidak menyimpang dari prosedur.

Sebagai pelaksanaan Undang-Undang Nomor 25 Tahun 2009 tentang Pelayanan Publik, maka diterbitkan Peraturan Pemerintah Nomor 96 Tahun 2012 dimana dalam pasal 22 ayat 1 menginstruksikan agar penyelenggara pelayanan publik memiliki dan menggunakan standar pelayanan. Standar pelayanan tersebut disusun dan kemudian ditetapkan sebagai acuan pada setiap penyelenggaraan pelayanan tanpa kecuali oleh lembaga yang bersangkutan. Standar pelayanan sendiri memiliki makna sebagai tolok ukur yang digunakan sebagai pedoman penyelenggaraan pelayanan publik dan acuan penilaian kualitas pelayanan sebagai kewajiban dan janji penyelenggara negara kepada masyarakat dalam rangka pelayanan yang berkualitas, cepat, mudah, terjangkau dan terukur. Untuk itu standar yang menjadi pedoman harus dapat dievaluasi karena memiliki parameter yang jelas dan bisa dipantau pelaksanaannya.

\subsection{Karakteristik Pelayanan}

Karakteristik pelayanan mempunyai kekuatan untuk mempengaruhi tingkat kepuasan pelanggan atau masyarakat. Hal ini dapat dilihat pada berbagai perumusan karakteristik yang dibuat oleh para ahli. Zeithaml, Berry dan Parasuraman (Fandy Tjiptono dan Anastasia Diana, 2003: 27) mengidentifikasikan lima karakteristik yang digunakan oleh para pelanggan dalam mengevaluasi kualitas jasa, yaitu:

1. Bukti langsung (tangible), Tangible adalah faktor yang mempengaruhi kepuasan pelanggan dari segi visual (berhubungan dengan lingkungan fisik). Tangible yang baik akan mempengaruhi persepsi pelanggan. Pada saat yang bersamaan aspek tangible ini juga merupakan salah satu sumber yang mempengaruhi harapan pelanggan. Aspek tangible meliputi fasilitas fisik, perlengkapan, pegawai, dan sarana komunikasi. 
2. Kehandalan (reliability), Reliability yaitu kemampuan memberikan pelayanan yang dijanjikan dengan segera dan memuaskan. Reliability berarti perusahaan menepati apa yang dijanjikan, baik mengenai pengantaran, pemecahan masalah, dan harga. Reliabilitas meliputi dua aspek utama, yaitu konsistensi kinerja (performance) dan sifat dapat dipercaya (dependability). Hal ini berarti perusahaan mampu menyampaikan jasanya secara benar sejak awal, memenuhi janjinya secara akurat dan andal, menyampaikan data secara tepat dan mengirimkan tagihan yang akurat.

3. Daya tanggap (responsiveness), Daya tanggap yaitu keinginan para staff untuk membantu para pelanggan dan memberikan pelayanan dengan tanggap. Beberapa contohnya adalah ketepatan waktu pelayanan, kecepatan memanggil kembali pelanggan, dan penyampaian layanan secara cepat. Dimensi ini menegaskan perhatian dan kecepatan waktu dalam hubungannya dengan permintaan pelanggan, pelayanan, komplain dari masalah yang terjadi.

4. Jaminan (assurance), Jaminan yang dimaksud adalah perilaku karyawan atau petugas pelayanan mampu menumbuhkan kepercayaan pelanggan terhadap perusahaan dan perusahaan dapat menciptakan rasa aman bagi para pelanggannya. Jaminan juga berarti bahwa para karyawan selalu bersikap sopan dan menguasai pengetahuan dan ketrampilan yang dibutuhkan untuk menanggapi setiap pertanyaan atau masalah pelanggan. Jaminan ini mencakup kemampuan, kesopanan, dan sifat dapat dipercaya yang dimiliki para staf, bebas dari bahaya, resiko atau keragu-raguan.

5. Empati, empati berarti perusahaan memahami masalah para pelanggannya dan bertindak demi kepentingan pelanggan, serta memberikan perhatian personal kepada para pelanggan dan memiliki jam operasi yang nyaman. Empati dalam pelayanan meliputi kemudahan dalam melakukan hubungan, komunikasi yang baik, dan memahami kebutuhan para pelanggan.

Sementara itu menurut Zeithaml, dkk dan Haywood Farmer (dalam Warella, 1997: 17), terdapat tiga karakteristik utama tentang pelayanan yaitu intangibility, heterogeneity dan inseparability. Intangibility berarti bahwa pelayanan pada dasarnya bersifat performance dan hasil pengalaman dan bukannya obyek. Kebanyakan pelayanan tidak dapat dihitung, diukur, diraba atau dites sebelum disampaikan untuk menjamin kualitas. Berbeda dengan barang yang dihasilkan oleh suatu pabrik yang dapat dites kualitasnya sebelum disampaikan pada pelanggan. Heterogeinity berarti pemakai jasa atau klien atau pelanggan memiliki kebutuhan yang sangat heterogen. Pelanggan dengan pelayanan yang sama mungkin mempunyai prioritas berbeda. Inseparability berarti bahwa produksi dan konsumsi suatu pelayanan tidak terpisahkan. Konsekuensinya di dalam industri pelayanan kualitas tidak direkayasa ke dalam produksi di sektor pabrik dan kemudian disampaikan kepada pelanggan. Kualitas terjadi selama penyampaian pelayanan, biasanya selama interaksi antara klien dan penyedia jasa.

\subsection{Kualitas Pelayanan}

Menurut Goetsch dan Davis (Fandy Tjiptono dan Anastasia Diana, 2003: 4), menyebutkan bahwa kualitas merupakan "Suatu kondisi dinamis yang berhubungan dengan produk, jasa, manusia, proses, dan lingkungan yang memenuhi atau melebihi harapan". Konsep kualitas meliputi usaha memenuhi harapan pelanggan, mencangkup produk jasa, manusia, proses dan lingkungan. Selanjutnya Fandy Tjiptono (2004: 121) menyebutkan: Ada dua faktor utama yang mempengaruhi kualitas jasa yaitu jasa yang diharapkan (expected service) dan 
jasa yang dirasakan atau dipersepsikan (perceived service). Apabila perceived service sesuai dengan expected service, maka kualitas jasa yang bersangkutan dipersepsikan baik atau positif. Sebaliknya jika perceived service lebih jelek dibandingkan expected service, maka kualitas jasa dipersepsikan negatif atau tidak baik.

Adapun menurut Atep Adya Barata (2003: 37), "Kualitas pelayanan terbagi menjadi dua bagian yaitu kualitas pelayanan internal dan eksternal". Masing-masing bagian tersebut dipengaruhi oleh beberapa faktor yang cukup penting, 1) Faktor yang mempengaruhi kualitas pelayanan internal (interaksi pegawai organisasi), yaitu pola manajemen umum organisasi, penyediaan fasilitas pendukung, pengembangan sumber daya manusia, iklim kerja dan keselarasan hubungan kerja, serta pola insentif. 2) Faktor yang mempengaruhi kualitas pelayanan eksternal (pelanggan eksternal), yaitu pola layanan dan tata cara penyediaan layanan, pola layanan distribusi jasa, pola layanan penjualan jasa, dan pola layanan dalam penyampaian jasa.

Sementara itu menurut Vincent Gaspersz (2011:41), terdapat faktor-faktor yang mempengaruhi persepsi dan ekspektasi pelanggan terhadap pelayanan, yaitu: 1) Kebutuhan dan keinginan yang berkaitan dengan hal-hal yang dirasakan pelanggan ketika ia sedang mencoba melakukan transaksi dengan perusahaan, 2) Pengalaman masa lalu ketika menggunakan jasa dari perusahaan, 3) Pengalaman dari teman-teman, dimana mereka akan menceritakan tentang kualitas pelayanan yang akan diterimanya, 4) Komunikasi melalui iklan dan pemasaran juga mempengaruhi persepsi dari pelanggan terhadap jasa yang akan diterimanya.

Beberapa aspek yang perlu diperhatikan untuk memperbaiki kualitas pelayanan, antara lain menurut Gaspersz (1997: 2):

1. Ketepatan waktu pelayanan. Hal-hal yang perlu diperhatikan disini berkaitan dengan waktu tunggu dan waktu proses.

2. Akurasi pelayanan. Berkaitan dengan reliabilitas pelayanan dan bebas dari kesalahankesalahan.

3. Kesopanan dan keramahan di dalam memberikan pelayanan. Ini terutama bagi mereka yang berinteraksi langsung dengan pelanggan eksternal.

4. Tanggung jawab. Berkaitan dengan penerimaan pelayanan dan penanganan keluhan dari pelanggan eksternal.

5. Kelengkapan. Menyangkut lingkup pelayanan dan ketersediaan sarana pendukung serta pelayanan kontemporer lainnya.

6. Kemudahan mendapatkan pelayanan. Berkaitan dengan kejelasan dan kemudahan petugas yang melayani.

7. Variasi model pelayanan. Berkaitan dengan inovasi untuk memberikan pola-pola baru pelayanan.

8. Pelayanan pribadi. Berkaitan dengan fleksibilitas, penanganan permintaan khusus dan lain-lain.

9. Kenyamanan dalam memperoleh pelayanan. Berkaitan dengan lokasi, ruang dan tempat pelayanan, kemudahan menjangkau, ketersediaan informasi, dan lain-lain.

10. Atribut pendukung pelayanan lainnya. Berkaitan dengan lingkungan, kebersihan, ruang tunggu, fasilitas musik, dan lain-lain. 
Parasuraman, et al., (Fandy Tjiptono, 2004: 690) mengidentifikasi sepuluh dimensi kualitas, yaitu:

1. Reliability, mencangkup dua hal pokok, yaitu konsistensi kerja (performance) dan kemampuan untuk dipercaya (dependability). Hal ini berarti perusahaan memberikan jasanya secara tepat semennjak saat pertama (right the frist time). Selain itu juga berarti bahwa perusahaan yang bersangkutan memenuhi janjinya, misalnya menyampaikan janjinya sesuai dengan jadwal yang disepakati.

2. Responsiveness, yaitu kemauan atau kesiapan para karyawan untuk memberikan jasa yang dibutuhkan pelanggan.

3. Competence, artinya setiap orang dalam suatu perusahaan memiliki ketrampilan dan pengetahuan yang dibutuhkan agar dapat memeerikan jasa tertentu.

4. Access, meliputi kemudahan untuk dihubungi dan ditemui. Hal ini berarti lokasi fasilitas jasa yang mudah dijangkau, waktu menunggu yang tidak terlalu lama, saluran komunikasi perusahaan mudah dihubungi, dan lain-lain.

5. Courtesy, meliputi sikap sopan santun, respek, perhatian, dan keramahan yang dimiliki para contact personnel (seperti resepsionis, operator telepon, dan lain-lain)

6. Communication, artinya memberikan informasi kepada pelanggan dalam bahasa yang mereka pahami, serta selalu mendengarkan saran dan keluhan pelanggan

7. Credibility, yaitu sifat jujur dan dapat dipercaya. Kredibilitas mencangkup nama perusahaan, reputasi perusahaan, karakteristik pribadi contact personnel, dan interaksi pelanggan;

8. Security, yaitu aman dari bahaya, risiko, atau keraguraguan. Aspek ini meliputi keamanan secara fisik (physical safety), keamanan finansial (financial security), dan kerahasiaan (confidentiality)

9. Understanding/Knowing the Customer, yaitu usaha untuk memahami kebutuhan pelanggan

10. Tangibles, yaitu bukti fisik dari jasa, bisa berupa fasilitas fisik, peralatan yang dipegunakan, representasi fisik dari jasa (misalnya kartu kredit plastik).

Dalam rangka Reformasi Birokrasi, untuk meningkatkan kualitas pelayanan publik secara berkelanjutan, maka perlu dilakukan evaluasi terhadap penyelenggaraan pelayanan publik, sehingga Pemerintah telah menerbitkan Peraturan Menteri Pendayagunaan Aparatur Negara Dan Reformasi Birokrasi Republik Indonesia Nomor 14 Tahun 2017 Tentang Pedoman Penyusunan Survei Kepuasan Masyarakat Unit Penyelenggara Pelayanan Publik. Pelaksanaan kegiatan pengukuran menggunakan 9 (sembilan) unsur dan masukan (saran/kritik) yang digunakan sebagai bahan evaluasi guna memperbaiki layanan yang sudah ada. Unsur yang ada dalam peraturan tersebut dari sisi kuantitas terlihat lebih sedikit jika dibandingkan dengan Keputusan Menteri Pendayagunaan Aparatur Negara Nomor KEP/25/M.PAN/2/2004 tentang Pedoman Umum Indeks Kepuasan Masyarakat yang menggunakan 14 unsur, tetapi dari sisi tinjauan isi pengukuran telah disempurnakan yaitu sudah mengacu pada Undang-Undang Nomor 25 tahun 2009 tentang Pelayanan Publik dan Undang-Undang Nomor 12 Tahun 2011 tentang Pembentukan Peraturan Perundangan. Kegiatan Survei Kepuasan Masyarakat juga menjadi salah satu bagian dari indikator evaluasi dalam instrumen Peraturan Menteri Pendayagunaan Aparatur Negara dan Reformasi Birokrasi Nomor 1 Tahun 2015 tentang Pedoman Evaluasi Kinerja Penyelenggara Pelayanan Publik. Didalam peraturan tersebut menyebutkan bahwa pelaksanaan Survei Kepuasan Masyarakat (SKM) dapat menggunakan beberapa teknik metodologi pengumpulan data, yaitu Desk Evaluation, Kuesioner dan Mystery Shopping. 
Kemudian pada tahun 2017 diterbitkan Peraturan Menteri Pendayagunaan Aparatur Negara Dan Reformasi Birokrasi Republik Indonesia Nomor 14 Tahun 2017 Tentang Pedoman Penyusunan Survei Kepuasan Masyarakat. Dalam peraturan ini unsur penilaian masih tetap sembilan unsur, hanya terdapat perubahan pada unsur maklumat diganti menjadi unsur sarana dan prasarana.

Hasil Survei Kepuasan Masyarakat, dimaksudkan untuk: 1) Mengetahui kelemahan atau kekuatan dari masing-masing unit penyelenggara pelayanan publik; 2) Mengukur secara berkala penyelenggaraan pelayanan yang telah dilaksanakan oleh unit pelayanan publik.; 3 ) Sebagai bahan penetapan kebijakan yang perlu diambil dan langkah perbaikan pelayanan; 4) Sebagai umpan balik dalam memperbaiki layanan. Masyarakat terlibat secara aktif mengawasi pelaksanaan penyelenggaraan pelayanan publik.

\subsection{Konsep Ideal Pelayanan Publik di Indonesia}

Pelayanan di Republik Indonesia yang terbaik masih mengedepankan sifat dan karakteristik dari jenis pelayanan. Memberi pelayanan bagi organisasi publik adalah sebuah kewajiban yang wajib kita laksanakan dengan penuh tanggung jawab. Hambatan tetap saja ada di mana beberapa permasalahan yang harus dihadapi dan dicarikan sebuah solusi yang tepat diantaranya kekurang sigapnya staf dalam menginformasikan dan membantu pelanggan, sikap staf yang tidak simpatik dan cenderung kurang aktif terkait tumpukan beban kerja yang terus bertambah dan menghantui setiap hari, tidak kompetennya staf dan tidak berpengalaman atau sampai kepada ketidakjujuran kepada masyarakat. Perbandingan prespektif kepuasan masyarakat di Indonesia dan negara maju sebagai berikut:

Tabel 2.1. Dimensi-Dimensi Pelayanan Yang Berkualitas ${ }^{4}$

\begin{tabular}{|c|c|}
\hline $\begin{array}{l}\text { INDEKS KEPUASAN MASYARAKAT } \\
\text { (INDONESIA) }\end{array}$ & $\begin{array}{l}\text { INDIKATOR KUALITAS PELAYANAN } \\
\text { (DI NEGARA MAJU) }\end{array}$ \\
\hline $\begin{array}{l}\text { 1. Kesederhanaan Prosedur Pelayanan } \\
\text { 2. Kesesuaian Persyaratan Pelayanan } \\
\text { 3. Kejelasan Petugas Pelayanan } \\
\text { 4. Kedisiplinan Petugas Pelayanan } \\
\text { 5. Kejelasan Wewenang \& Tanggungjawab } \\
\text { 6etugas Pelayanan } \\
\text { 7. Keahlian dan Ketrampilan Petugas Pelayanan } \\
\text { 8. Keadilan Mendapatkan Pelayanan } \\
\text { 9. Kesopanan \& Keramahan Petugas } \\
\text { 10. Kewajaran Biaya Pelayanan } \\
\text { 11. Kepastian Biaya Pelayanan } \\
\text { 12. Kepastian Jadwal Pelayanan } \\
\text { 13. Kenyamanan Lingkungan } \\
\text { 14. Keamanan Pelayanan }\end{array}$ & $\begin{array}{l}\text { 1. Ketepatan, Akurasi } \\
\text { 2. Efektivitas \& Efikasi } \\
\text { 3. Keandalan } \\
\text { 4. Responsif } \\
\text { 5. Kehangatan, Kepedulian, Kepedulian } \\
\text { 6. Jaminan } \\
\text { 7. Efisiensi } \\
\text { 8. Daya Tahan / Kontinuitas } \\
\text { 9. Konsistensi } \\
\text { 10. Kenyamanan } \\
\text { 11. Keamanan } \\
\text { 12. Ketepatan waktu } \\
\text { 13. Aksesibilitas / Ketersediaan Layanan } \\
\text { 14. Kelengkapan Kualitas yang Dirasakan }\end{array}$ \\
\hline
\end{tabular}

Tabel diatas menunjukkan kalau pelayanan di Indonesia masih mengedepankan penerapan prosedur yang konsisten dibanding dengan akurasi dan efektifitas dan efisiensi pelayanan,

4 Makalah M Irvan Islamy, 2008 Manajemen Komplain dalam RangkaMeningkatkan Kualitas Pelayanan Publik Guru Besar Kebijakan Publik Fakultas Ilmu Administrasi Universitas Brawijaya hal 9 
sehingga dapat ditebak, pelayanan baik pasti akan sedikit mahal tetapi di negara maju pelayanan baik mencerminkan efektifitas dan akurasi pelayanan, sehingga pelayanan Indonesia di mana pun berada relatif lebih mahal dibanding di negara maju. Hal ini diperparah oleh mental aparat yang kurang responsif terhadap permintaan kebutuhan masyarakat sehingga masyarakan sering menggunakan jasa perantara untuk menghindari belitan jaring pelayanan pemerintah.

Jasa pelayanan publik memiliki sifat Intangible, artinya tidak dapat dilihat, dirasa, dicium, atau diraba sebelum ia melakukan transaksi secara langsung, dalam hal ini organisasi pemerintah dan konsumen (masyarakat) melakukan pertukaran jasa untuk itu jika sekali mereka melakukan transaksi pastinya konsumen akan memiliki persepsi yang beragam. Produk-produk intangible diyakini sulit untuk dievaluasi, karena bisa menimbulkan bias ketidakpastian, para pemohon seringkali menggunakan parameter simbol, tanda, petunjuk, atau bukti fisik kualitas jasa yang dihasilkan ${ }^{5}$. Kesimpulan atas kualitas jasa yang dihasilkan berdasarkan aspek tempat (place), orang (people), peralatan (equipment), komunikasi (communication), simbol (symbol), dan harga (price) di mana tiap orang berbeda bergantung pengalaman yang mereka dapati dalam mengurus dokumen sehingga sangat subjektif.

Ke depan kompetisi akan semakin terbuka di era globalisasi, dorongan untuk membangun pemerintahan yang digerakkan pelanggan (building a customer driven government) semakin memperbaiki manajemen pelayanan, semakin strategis dan menjadi variabel penentu dalam memenangkan kompetisi ini. Oleh karena itu, perlunya perubahan perspektif manajemen pelayanan yang mengubah fokus manajemen di Kantor Pertanahan. Perubahan perspektif yang dimaksud, menurut Lovelock, sebagai berikut:

1. Dari berdasarkan daya manfaat produk menjadi daya manfaat total dalam hubungan dengan pengguna jasa. (from the product based utility in he customer relationship).

2. Dari transaksi jangka pendek menjadi hubugan Jangka panjang (from short-from transaction to long from relationship).

3. Dari kualitas inti (baik barang maupun jasa) kualitas teknis dari suatu produk pada kualitas yang diharapkan dan dipersepsikan para pengguna jasa dalam mempertahankan hubungan dengan pengguna jasa (from care product) (good or service) quality the technical quality of the outcome to total customer perceived quality in enduring customer relationship).

4. Dari menghasilkan solusi teknis sebagai proses kunci dalam organisasi menjadi pengembangan daya manfaat dan kualitas keseluruhan sebagai proses kuncinya. (from production of the technical collection as the key process in the organization to developing total utility and total quality as the key process) ${ }^{6}$.

Datangnya era pelayanan terbaik kepada pelanggan. sangat relevan dengan prinsip pengembangan organisasi yakni terwujudnya a smaller, better, faster and cheaper government, yang menurut bahasa Osborne dan Gaebler bertumpu pada prinsip customer driven government. Instrumennya adalah pembuktian model mental para birokrat untuk lebih suka melayani. Model yang pertama, menempatkan pemimpin puncak birokrasi berada pada piramida tertinggi dengan warga negara (customer) berada pada posisi bawah. Sebaliknya, model yang kedua menempatkan warga Negara (customer) berada pada puncak piramida dengan pemimpin birokrasi berada pada posisi paling bawah, di mana sasaran akhir dan pengembangan model ini, tidak lain adalah dicapainya pelayanan terbaik kepada masyarakat.

5 Fandy Tjiptono, Service Management,.2008 Penerbit Andi. Yogjakarta Hal 15

6 Christoper Lovelock, Product Plus: How Product Service Competitive Advantge. 1988 New York : Mc Graw Hill.p 9 
Berdasarkan pengamatan penulis yang tak kalah penting di sini adalah pengembangan visi dan misi aparat Organisasi Pemerintah dalam memberikan pelayanan kepada publik. Sejalan dengan semangat reformasi pelayanan di Organisasi Pemerintah, wajib lebih mengedepankan pengembangan sumber daya manusia pada visi, misi, inovasi, dan kemampuan aparat untuk melakukan semangat melayani dalam pelaksanaan tugas mereka. Semangat ini merupakan semangat kerja yang lebih berorientasi menghasilkan daripada menghabiskan anggaran dan pada waktu yang sama kepentingan publik justru dapat ditingkatkan pelayanannya ${ }^{7}$.

\subsection{Kantor Pertanahan Penentu Keberhasilan Pelayanan Pertanahan Berkualitas}

Upaya merespon undang-undang pelayanan publik telah menjadikan pertimbangan utama Kementerian Agraria dan Tata Ruang/Badan Pertanahan Nasional untuk membuat Peraturan Kepala Badan Pertanahan Nasional Nomor 1 tahun 2010. Di dalamnya terdapat pasal-pasal yang mengatur tentang pelayanan pertanahan secara sistematis, terperinci dan konsisten yang artinya secara yuridis normatif pelayanan di Kantor Pertanahan seluruh Indonesia wajib berpedoman pada aturan ini. Peraturan ini dilengkapi beberapa penjelasan secara rinci ada beberapa poin penting untuk kita telaah bersama, yaitu:

1. Pemberian pelayanan kepada masyarakat supaya memberikan kenyamanan dengan penataan loket sesuai Peraturan Kepala Badan Pertanahan Nasional Nomor 3 Tahun 2010 tentang Loket Pelayanan Pertanahan.

2. Penyederhanaan persyaratan mengenai pernyataan telah dipasang tanda batas, penguasaan fisik dan tidak sengketa cukup dimuat pada satu lembar blangko permohonan yang bermaterai cukup, sehingga dapat meringankan beban masyarakat.

3. Waktu pelayanan dihitung secara efektif untuk masing-masing unit kerja dan tidak termasuk waktu pengiriman. Waktu tersebut adalah waktu terlama untuk penyelesaian setiap layanan dan dimungkinkan dapat diselesaikan lebih cepat, kecuali Hak Tanggungan tetap sebagaimana waktu yang telah ditetapkan (tidak boleh kurang dan tidak boleh lebih).

4. Apabila ternyata terdapat jenis kegiatan pelayanan yang diperlukan oleh masyarakat tapi belum diatur pada peraturan ini, agar diselesaikan sesuai dengan ketentuan peraturan perundangan-undangan yang berlaku.

5. Peraturan ini bertujuan menyederhanakan dan mempermudah proses pelayanan pertanahan sebagaimana diatur pada Keputusan Kepala Badan Pertanahan Nasional.

6. Kepala Kantor Wilayah Badan Pertanahan Nasional dan Kepala Kantor Pertanahan wajib melakukan pembinaan, pengendalian dan pengawasan kepada seluruh unit kerja yang berada di lingkungan kerjanya sehingga proses pelayanan dipastikan dapat berjalan dengan baik dan tepat waktu.

7. Diwajibkan untuk menyampaikan laporan pelaksanaan pelayanan sesuai dengan peraturan ini setiap bulan secara berjenjang.

Substansi Peraturan Kepala Badan Pertanahan Nasional Nomor 1 tahun 2010 tentang Standar Pelayanan dan Pengaturan Pertanahan telah mengikat secara internal aparatur Kantor Pertanahan dalam memberikan layanan pertanahan.

7 H.R. Riyadi Soeprapto, Heru Ribawanto, Iman Hanafi Pengembangan Sumber Daya Aparatur Daerah di Era Reformasi Kasus Kabupaten Trenggalek, Jurnal Administrasi Negara, Vol. I, No.1, September 2000: 46 - 57 
Dalam rangka Reformasi Birokrasi, untuk meningkatkan kualitas pelayanan publik secara berkelanjutan, maka perlu dilakukan evaluasi terhadap penyelenggaraan pelayanan publik melalui survei kepuasan masyarakat (SKM). Hasil Survei Kepuasan Masyarakat, dimaksudkan untuk: 1) Mengetahui kelemahan atau kekuatan dari masing-masing unit penyelenggara pelayanan publik; 2) Mengukur secara berkala penyelenggaraan pelayanan yang telah dilaksanakan oleh unit pelayanan publik.; 3) Sebagai bahan penetapan kebijakan yang perlu diambil dan langkah perbaikan pelayanan; 4) Sebagai umpan balik dalam memperbaiki layanan. Masyarakat terlibat secara aktif mengawasi pelaksanaan penyelenggaraan pelayanan publik. 



\subsection{Metode Penelitian}

Metode yang digunakan dalam penelitian ini adalah dengan menggunakan metode penelitian survei. Penelitian survei adalah penelitian kuantiatif dengan menggunakan pertanyaan terstruktur/sistematis yang sama kepada banyak orang, untuk kemudian dari semua jawaban yang diperoleh peneliti dicatat, diolah, dan dianalisis. Pertanyaan yang terstruktur/sistematis tersebut kemudian tertuang dalam kuesioner.

Secara sederhana penelitian survei merupakan cara untuk mengumpulkan informasi dengan menggunakan instrumen penelitian (pedoman wawancara atau angket) yang diajukan kepada responden dengan tujuan untuk meneliti karakteristik atau sebab akibat antar variabel tanpa adanya campur tangan peneliti. Penelitian dilakukan pada populasi yang besar, sedangkan data yang dipelajari adalah data sampel yang diambil dari populasi tersebut untuk mengambil generalisasi dari pengamatan.

Setelah dilakukan survei maka data data yang telah berhasil didapat akan diolah dengan menggunakan metode penelitian kuantitatif. Metode penelitian kuantiatif merupakan penelitian empiris dimana data dalam bentuk sesuatu yang dapat dihitung/angka. Penelitian kuantitatif memperhatikan pada pengumpulan dan analisis data dalam bentuk numerik, bersifat obyektif serta bisa diukur karena merepresentasikan sebuah makna.

\subsection{Populasi dan Sampel Penelitian}

Pelaksanaan penelitian ini menggunakan batasan-batasan sebagai pedoman sehingga baik saat masih penyusunan riset desain, pelaksanaan pengumpulan data di lapangan, pengolahan hingga saat penyajian data dan analisisnya. Beberapa batasan tersebut antara lain:

1. Jenis Pelayanan yang akan diteliti meliput seluruh jenis pelayanan yang dilakukan oleh Kantor Pertanahan. Pengelompokan terhadap jenis pelayanan tertentu dilakukan berdasarkan data isian dalam kuesioner, sehingga dalam penelitian ini tim belum menentukan jumlah dan jenis pelayanan tertentu;

2. Populasi penelitian adalah masyarakat yang telah mendapatkan pelayanan pertanahan baik secara langsung maupun melalui kuasa;

3. Teknik Pemilihan Lokasi dan Sampel

a. Membagi provinsi berdasarkan jumlah berkas/volume permohonan layanan pertanahan berdasarkan lima kategori jumlah layanan: yaitu Kantor Pertanahan dengan volume pelayanan sangat tinggi (1), Kantor Pertanahan dengan volume pelayanan tinggi (2), Kantor Pertanahan dengan volume pelayanan sedang (5), Kantor Pertanahan dengan volume pelayanan rendah (12), dan Kantor Pertanahan dengan volume sangat rendah (14).

b. Memilih 12 Provinsi secara Stratified Random Sampling

\begin{tabular}{|l|l|l|l|}
\hline $1 / 33 * 12$ & $=$ & 0.36 & $=1$ \\
\hline $2 / 33 * 12$ & $=$ & 0.73 & $=1$ \\
\hline $5 / 33 * 12$ & $=$ & 1.82 & $=1$ \\
\hline $12 / 33 * 12$ & $=4.36$ & $=4$ \\
\hline $14 / 33 * 12$ & $=5.09$ & $=5$ \\
\hline Jumlah & & $=12$ \\
\hline
\end{tabular}


c. Provinsi yang terpilih secara Stratified Random Sampling:

1). Jawa Tengah (Sangat Tinggi)

2). Jawa Timur (Tinggi)

3). DKI Jakarta (Sedang)

4). DI Yogyakarta (Rendah)

5). Kalimantan Timur (Rendah)

6). Kalimantan Selatan (Rendah)

7). Kepulauan Riau (Rendah)

8). Sulawesi Tenggara (Sangat Rendah)

9). Bengkulu (Sangat Rendah)

10).Papua (Sangat Rendah)

11).Gorontalo (Sangat Rendah)

12).Maluku Utara (Sangat Rendah)

Pemilihan sampel responden penelitian dilakukan secara acak pada masyarakat yang telah mendapatkan pelayanan pertanahan baik secara langsung maupun melalui kuasa di setiap kabupaten/kota setempat, termasuk responden PTSL.

4. Lokasi Sampel Penelitian

Dari 12 Kanwil BPN Provinsi sampel kemudian terpilih masing-masing 2 (dua) Kantor Pertanahan yaitu Kantor Pertanahan yang berada di ibukota provinsi dan Kantor Pertanahan yang berbatasan. Kabupaten/Kota sebagai berikut:

a. Jawa Tengah: Kota Semarang dan Kabupaten Semarang;

b. Jawa Timur: Surabaya I dan Kabupaten Sidoarjo;

c. DKI Jakarta: Jakarta Pusat dan Jakarta Utara;

d. Daerah Istimewa Yogya: Kota Yogya dan Kabupaten Sleman;

e. Kalimantan Timur: Kota Samarinda dan Kabupaten Kutai Kertanegara;

f. Kalimantan Selatan: Kota Banjarmasin dan Kabupaten Banjar;

g. Kepulauan Riau: Kota Tanjung Pinang dan Kabupaten Bintan;

h. Sulawesi Tenggara: Kota Kendari dan Kabupaten Konawe Selatan;

i. Bengkulu: Kota Bengkulu dan Kabupaten Bengkulu Tengah;

j. Papua: Kota Jayapura dan Kabupaten Jayapura;

k. Gorontalo: Kota Gorontalo dan Kabupaten Gorontalo;

I. Maluku Utara: Kota Ternate dan Kabupaten Halmahera Barat.

5. Penetapan Jumlah Responden

Penetapan jumlah responden berdasarkan Sampel Morgan dan Krejcie, responden yang dipilih adalah pemohon yang pernah mengakses layanan pertanahan. 


\subsection{Teknik Pengumpulan Data Penelitian}

1. Pengumpulan data primer dengan metode survei melalui pengisian kuesioner pada masyarakat terhadap 9 unsur pelayanan yang telah ditetapkan. Pengisian kuesioner dilakukan oleh peneliti dan pegawai fungsional umum Puslitbang Kementerian Agraria dan Tata Ruang/Badan Pertanahan Nasional, pendamping dari Kantor Wilayah BPN Povinsi, dan enumerator dari Kantor Pertanahan Kabupaten/Kota. Wawancara mendalam (indept interview) dilakukan untuk mendapatkan penjelasan dari 9 unsur (ruang lingkup) yang telah dijawab oleh responden;

2. Analisis kondisi Kantor Pertanahan dalam rangka mendukung pelayanan pertanahan berdasarkan observasi pada Kantor Pertanahan sampel;

3. Pengumpulan data sekunder dengan metode studi literatur melalui teknik inventarisasi dokumen yang terkait dan relevan pada materi penelitian.

\subsection{Teknik Pengolahan dan Analis}

1. Gambaran IKM dalam pelayanan pertanahan di Kantor Pertanahan Kabupaten/Kota

a. Nilai rata-rata unsur (ruang lingkup) pelayanan

Kuesioner yang masuk akan diolah dalam data entri komputer untuk mendapatkan nilai SKM-nya. Nilai SKM dapat dihitung dengan pendekatan "Nilai rata-rata tertimbang" pada masing-masing unsur pelayanan, untuk menghitung dan mendapatkan nilai survei kepuasan masyarakat yang terdiri dari 9 unsur pelayanan sertaagar setiap unsur pelayanan memiliki nilai penimbang yang sama maka digunakan rumus sebagai berikut:

1). Bobot Nilai Rata-Rata Tertimbang $=\frac{\text { Jumlah Bobot }}{\text { Jumlah Unsur }}=\frac{1}{9}=0,11$

Agar mendapatkan nilai SKM unit pelayanan digunakan nilai rata-rata tertimbang $(0,11)$ menggunakan rumus sebagai berikut:

2). Nilai SKM $=\frac{\text { Total Dari Nilai Persepsi Per Unsur }}{\text { Total Unsur Yang Diisi }} \times$ Nilai Penimbang

Selanjutnya agar memudahkan interpretasi nilai SKM antara 25-100 maka angka hasil penilaian pada tahap sebelumnya tersebut dikonversikan menggunakan nilai 25 melalui rumus berikut:

3). Nilai SKM Unit Pelayanan $\times 25$

b. Nilai Persepsi, Interval SKM, Interval Konversi SKM, Mutu Pelayanan dan Kinerja Unit Pelayanan.

Agar memudah penilaian kinerja dari unit pelayanan yang telah disurvei, maka digunakan interval seperti pada tabel 3.1. 
Tabel 3.1. Interval Nilai Survei Kepuasan Masyarakat

\begin{tabular}{|c|l|c|c|l|}
\hline $\begin{array}{c}\text { NILAI } \\
\text { PERSEPSI }\end{array}$ & NILAI INTERVAL & $\begin{array}{c}\text { NILAI INTERVAL } \\
\text { KONVERSI SKM }\end{array}$ & $\begin{array}{c}\text { MUTU } \\
\text { PELAYANAN }\end{array}$ & $\begin{array}{c}\text { KINERJA UNIT } \\
\text { PELAYANAN }\end{array}$ \\
\hline 1 & $1,00-2,5996$ & $25,00-64,99$ & D & Tidak Baik \\
\hline 2 & $2,60-3,064$ & $65,00-76,60$ & C & Kurang Baik \\
\hline 3 & $3,0644-3,532$ & $76,61-88,30$ & B & Baik \\
\hline 4 & $3,5324-4,00$ & $88,31-100,00$ & A & Sangat Baik \\
\hline
\end{tabular}

Sumber: Kementerian PAN dan RB 2017

Adapun terhadap kesembilan unsur (ruang lingkup) yang akan dilihat sesuai dengan Peraturan Menteri Pemberdayaan Aparatur Negara dan Reformasi Birokrasi Nomor 14 Tahun 2017, yaitu:

Tabel 3.2. Unsur (Ruang Lingkup) Pelayanan

\begin{tabular}{|c|l|}
\hline NO. & \multicolumn{1}{|c|}{ UNSUR PELAYANAN } \\
\hline U1 & Persyaratan \\
\hline U2 & Sistem, Mekanisme, Prosedur \\
\hline U3 & Waktu Penyelesaian \\
\hline U4 & Biaya/Tarif \\
\hline U5 & Produk Spesifikasi Jenis Pelayanan \\
\hline U6 & Kompetensi Pelaksana \\
\hline U7 & Perilaku Pelaksana \\
\hline U8 & Penanganan Pengaduan, Saran dan Masukan \\
\hline U9 & Sarana dan Prasarana \\
\hline
\end{tabular}

Sumber: Permen PAN dan RB No. 14 Tahun 2017

2. Gambaran kondisi Kantor Pertanahan Kabupaten/Kota melalui observasi

Untuk melihat kondisi kantor dalam mendukung kegiatan pelayanan pertanahan menggunakan batasan 2 (dua) unsur besar yaitu fasilitas dan kualitas loket pelayanan sesuai dengan Peraturan Kepala BPN No. 3 Tahun 2010 tentang Loket (termuat dalam Bab I pada Subbab Ruang Lingkup Materi dan Lampiran 3). Dari kedua batasan unsur tersebut kemudian ditabulasi sehingga akan diketahui kondisi sebenarnya Kantor Pertanahan sampel, khusunya berkaitan dengan loket pelayanan dan untuk selanjutnya dapat dilakukan analisis penjabaran. 



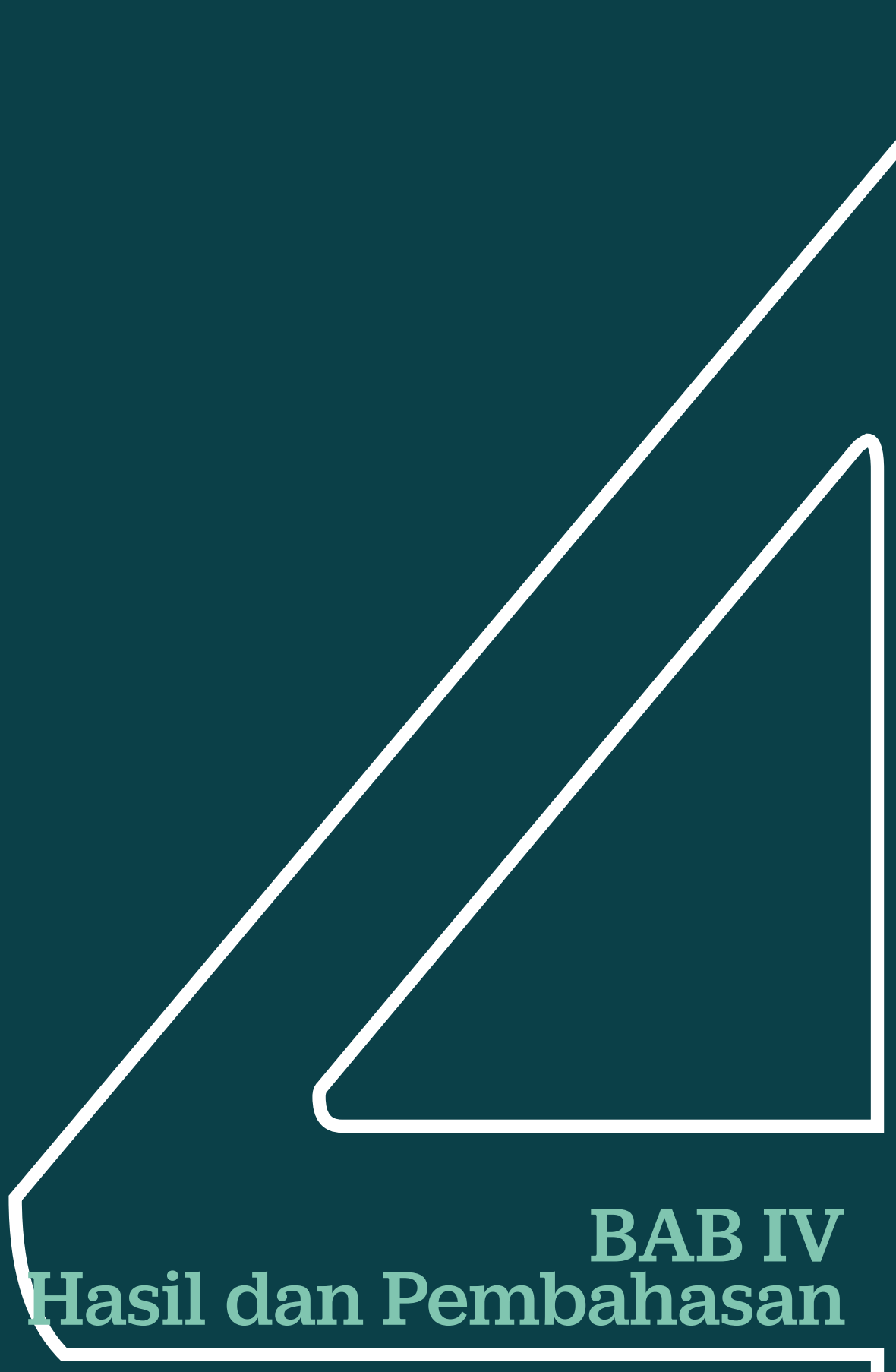




\subsection{Karakteristik Responden}

\subsubsection{Karakter Responden Menurut Umur}

Responden pengguna layanan pertanahan, baik pemohon sendiri maupun kuasa di lokasi sampel didominasi oleh mereka yang berumur 30-40 dan 40-50 tahun, yakni masing-masing sebesar $27 \%$. Kedua kelompok umur tersebut merupakan usia produktif, dan juga termasuk dalam usia yang masih sanggup dan energik dalam melakukan pengurusan tanah, baik tanah miliknya maupun pihak lain. Kelompok umur responden yang paling sedikit adalah umur lebih dari 60 tahun (8\%), dimana kondisi fisik sudah mulai berkurang untuk melakukan pengurusan tanah. Berikut distribusi responden dari beberapa kelompok umur di lokasi sampel.

\section{Umur Responden}

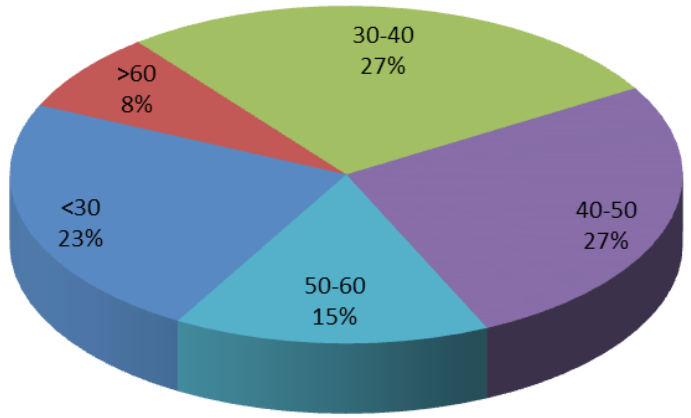

Gambar 4.1. Karakter Responden Menurut Umur

\subsubsection{Karakter Responden berdasarkan Jenis Kelamin}

Dalam Peraturan Pemerintah Nomor 24 Tahun 1997 tentang Pendaftaran Tanah tidak menunjukkan adanya perbedaan atau klasifikasi berdasarkan gender dalam persoalan kepemilikan tanah. Namun, secara kultural pihak perempuan memiliki keterbatasan lebih besar dalam mengakses hak-hak sumber daya yang dimilikinya, termasuk dalam upaya melakukan pengurusan tanah. Hal ini dapat dilihat dari responden di lokasi sampel berdasarkan jenis kelamin. Responden yang terpilih menjadi subyek pengumpulan informasi Survei Kepuasan Masyarakat terhadap layanan pertanahan di lokasi sampel sebagian besar merupakan laki-laki (57\%) sedangkan untuk perempuan $43 \%$. Jumlah tersebut tidak jauh berbeda, karena dalam perkembangannya, perempuan di Indonesia mulai berdaya dalam pengurusan tanah, baik yang merupakan miliknya maupun milik pihak lain. 


\section{Jenis Kelamin Responden}

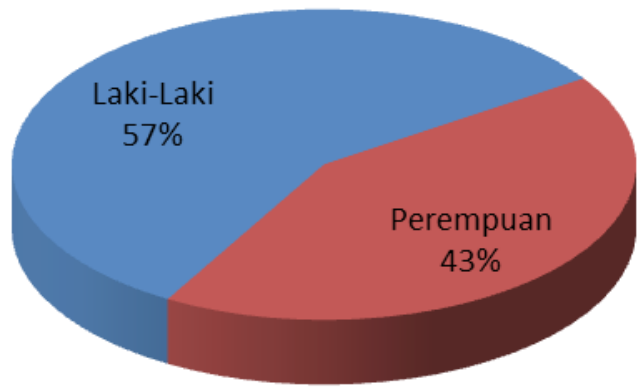

Gambar 4.2. Karakter Responden berdasarkan Jenis Kelamin

\subsubsection{Karakteristik Responden berdasarkan jenis kelamin pada setiap Kantor Pertanahan}

Jika dilihat lebih rinci di masing-masing Kantor Pertanahan sampel, diketahui bahwa jenis kelamin responden didominasi oleh laki-laki, kecuali di Kota Samarinda, Kota Semarang, Kota Bengkulu, Kabupaten Semarang, dan Kabupaten Gorontalo. Pada kabupaten/ kota tersebut mulai terlihat keberdayaan perempuan dalam mengakses tanah yang lebih banyak dibanding laki-laki.

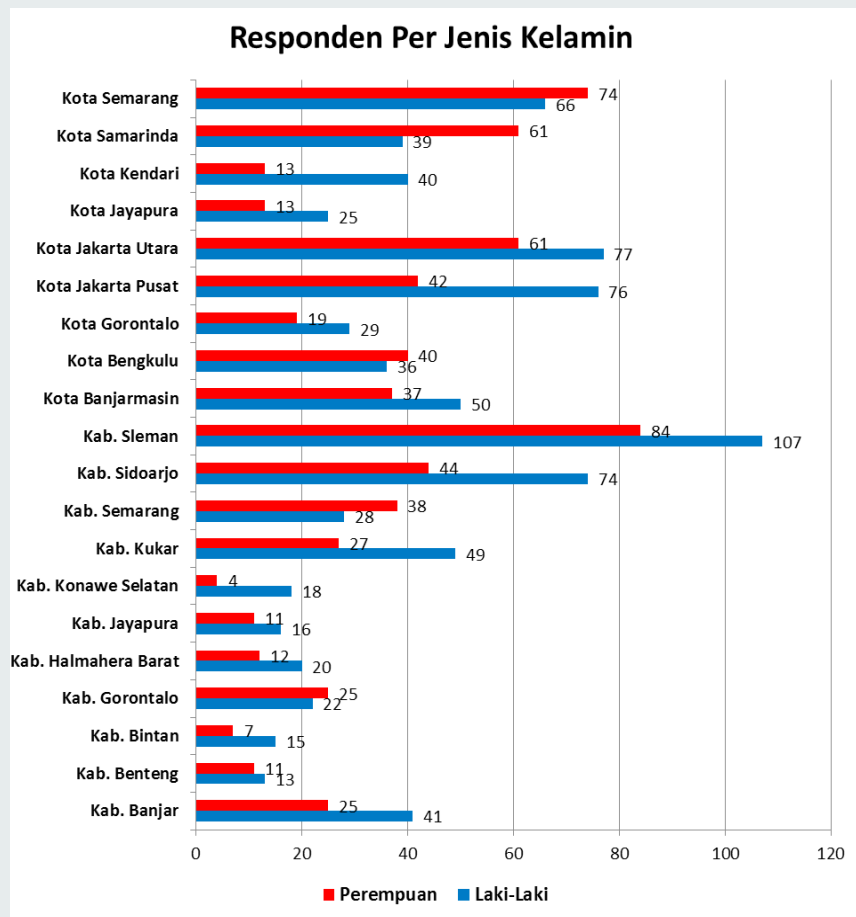

Gambar 4.3. Karakter Responden berdasar Jenis Kelamin di Masing-masing Kantor Pertanahan 


\subsubsection{Karakteristik Responden berdasarkan Pekerjaan Utama}

Pekerjaan utama masyarakat pengguna layanan pertanahan di lokasi sampel dan terpilih sebagai responden sebagian besar adalah pegawai swasta (53\%). Besarnya jumlah responden dalam kategori pegawai swasta karena didominasi oleh responden yang bekerja sebagai staf di kantor jasa PPAT. Kantor jasa PPAT membantu masyarakat dalam pengurusan tanah, terutama bagi masyarakat yang belum memahami prosedur pengurusan pertanahan dan yang tidak mempunyai waktu untuk mengurusnya. Responden terbanyak berikutnya adalah yang berprofesi sebagai wiraswasta/usahawan dengan besaran $17 \%$. Pekerjaan responden lainnya yang paling sedikit adalah mereka yang bekerja sebagai pegawai BUMN/BUMD dan pelajar/ mahasiwa, masing-masing sebesar $1 \%$. Pekerjaan lainnya yang menjadi responden yakni sebesar $17 \%$, yang banyak terdiri dari buruh bangunan dan ibu rumah tangga.

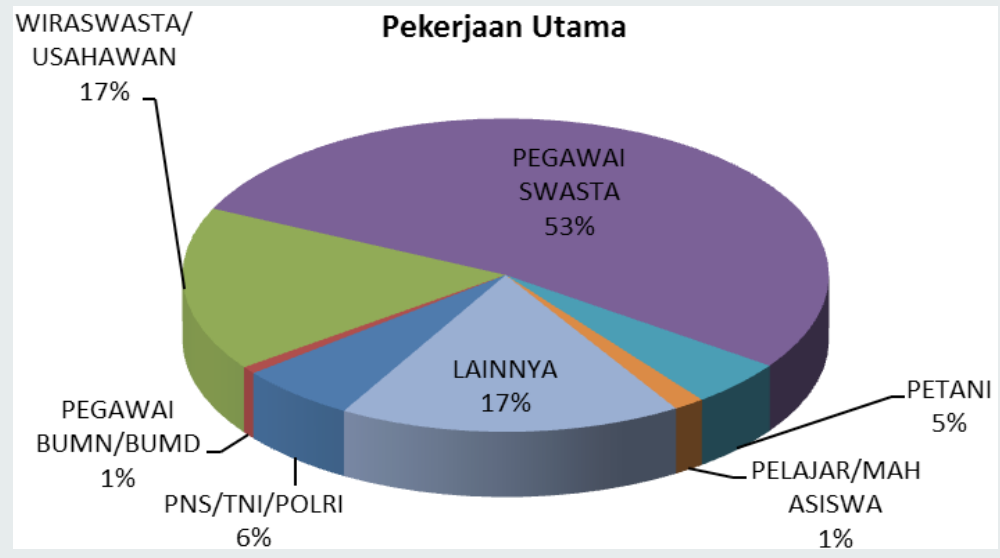

Gambar 4.4. Karakteristik Responden berdasarkan Pekerjaan Utama

\subsubsection{Karakteristik Responden Menurut Pendidikan}

Pengguna layanan pertanahan yang menjadi responden dalam kegiatan Survei Kepuasan Masyarakat dari 24 Kantor Pertanahan Kabupaten/Kota di Indonesia didominasi oleh jenjang pendidikan SMA dan yang sederajat yakni sebesar $41 \%$. Jumlah responden pada kelompok SMA, sebagian besar merupakan kuasa dari staf PPAT. Staf PPAT merupakan perpanjangan tangan dari PPAT untuk mengurus sertipikat tanah. Selain itu, pada kelompok usia SMA juga banyak terdapat kuasa yang bukan dari staf PPAT, melainkan membuka biro jasa mandiri dalam pengurusan sertipikat tanah. Pengurusan sertipikat tanah dan layanan pertanahan lainnya mampu menyerap lowongan pekerjaan yang cukup menjanjikan terutama bagi lulusan SMA atau sederajat.

Kelompok jenjang pendidikan berikutnya adalah S1 atau DIV, yakni sebesar $32 \%$. Banyaknya jumlah responden pada tamatan pendidikan S1 atau DIV yang mengakses layanan pertanahan didasari juga oleh kemampuan seseorang seperti pengetahuan tentang pertanahan, serta keberanian untuk datang dan mengurus sendiri. Karakteristik responden berdasarkan pendidikan secara lengkap dapat dilihat pada Gambar 4.5. 


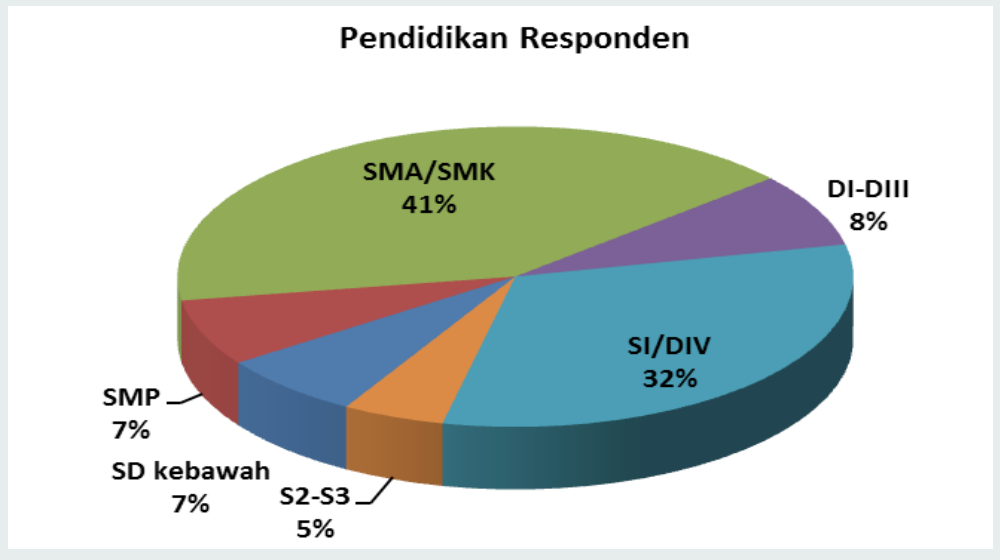

Gambar 4.5. Karakteristik Responden Berdasarkan Pendidikan

\subsubsection{Karakteristik Responden Berdasarkan Jenis Layanan}

Responden yang melakukan pengurusan layanan pengecekan mendominasi pemohon yang menjadi responden survei ini. Terlihat seperti pada Gambar 4.6, responden yang melakukan pengurusan pelayanan pengecekan sebesar $30 \%$. Pemohon yang melakukan pengurusan melalui layanan PTSL juga tercatat cukup besar, yakni 25\% dari jumlah responden. Responden yang mengurus pelayanan peralihan hak memiliki porsi sebesar $22 \%$ hampir imbang dengan responden yang melakukan pengurusan melalui layanan PTSL. Hal serupa juga terjadi pada responden yang melakukan pengurusan untuk pelayanan pendaftaran pertama kali dan roya. Di mana besaran porsi keduanya masing-masing adalah $12 \%$ responden pengurusan pendaftaran pertama kali dan sebesar $11 \%$ responden yang mengurus roya.

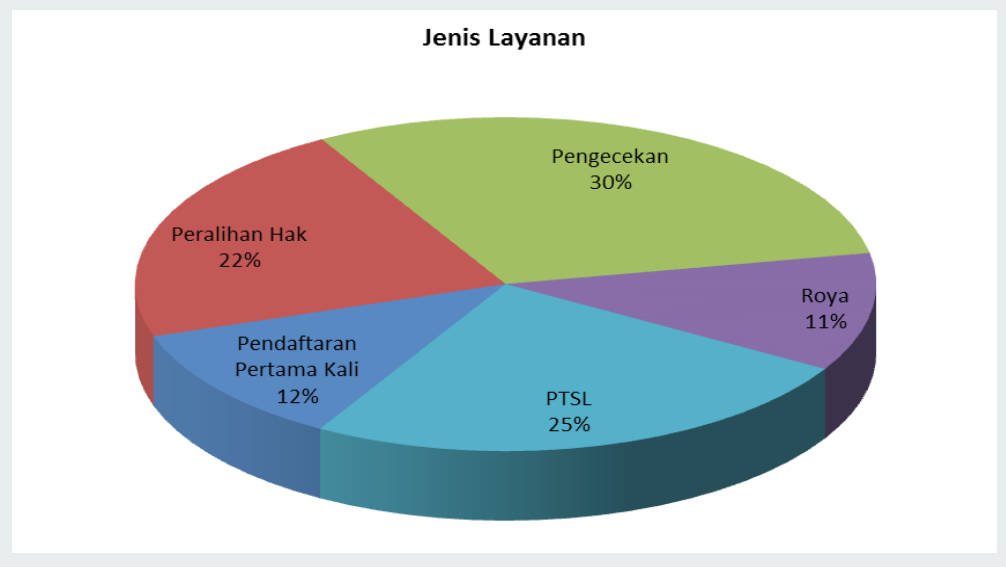

Gambar 4.6. Karakteristik Responden Berdasarkan Jenis Layanan

\subsubsection{Karakteristik Responden Berdasarkan Status Pemohon}

Karakteristik responden berdasarkan status pemohon, dapat dilihat seperti pada diagram yang tersaji pada Gambar 4.7. Responden yang melakukan pengurusan secara langsung memiliki 
porsi sebesar $54 \%$ jauh lebih besar daripada responden yang melakukan pengurusan secara tidak langsung. Responden yang melakukan pengurusan secara tidak langsung sebesar $46 \%$ dari keseluruhan responden. Lebih besarnya porsi persentase responden yang mengurus secara langsung menunjukkan bahwa sebagian besar masyarakat mempercayai Kantor Pertanahan memberikan kemudahan pada pelayanannya. Responden yang melakukan pengurusan secara tidak langsung, kemungkinan lebih dikarenakan ketidakluangan waktu mereka dalam melakukan pengurusan. Mereka mempercayakan pengurusan pelayanan pertanahan yang mereka butuhkan melalui jasa orang yang dipercaya dengan kuasa atau melalui kantor PPAT.

\section{Status Pemohon}

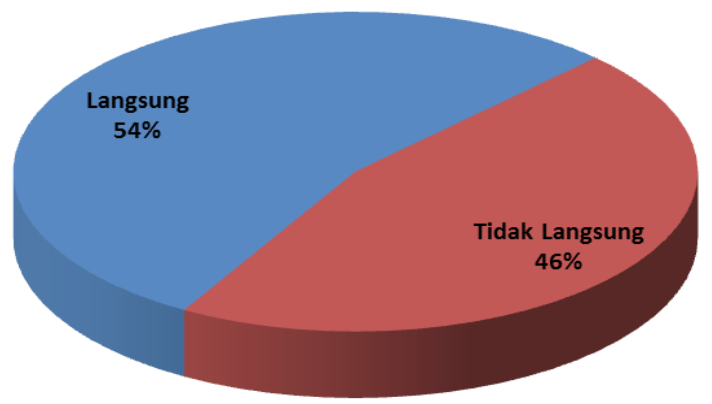

Gambar 4.7. Karakteristik Responden Berdasarkan Status Pemohon

\subsection{Pengukuran Survei Kepuasan Masyarakat (SKM)}

\subsubsection{Nilai SKM Menurut Provinsi}

Terdapat dua belas provinsi yang menjadi lokasi sampel survei kepuasan masyarakat. Hasil perhitungan menunjukkan nilai SKM rata-rata nasional sebesar 76,35. Nilai ini hanya berselisih 0,32 poin untuk menuju kategori baik. Sebanyak 6 provinsi memiliki nilai SKM di bawah ratarata nasional antara lain Provinsi Jawa Timur, Sulawesi Tenggara, dan DKI Jakarta. Tiga provinsi yang menempati nilai terendah SKM yaitu Provinsi Bengkulu $(70,73)$, Jawa Tengah $(70,82)$, dan Papua $(73,99)$. Demikian pula terdapat enam provinsi yang mempunyai niali SKM di atas nilai rata-rata nasional. Provinsi-provinsi tersebut antara lain DI Yogyakarta, Maluku Utara, Gorontalo, Kalimantan Timur, Kalimantan Selatan, dan Kepulauan Riau. Dari keenam provinsi dengan nilai SKM di atas rata-rata nasional tersebut, lima provinsi memiliki nilai SKM dengan kategori 'Baik' antara lain DI Yogyakarta $(81,24)$, Maluku Utara $(80,70)$, Gorontalo $(80,08)$, Kalimantan Timur $(77,97)$, dan Kalimantan Selatan $(77,18)$. Provinsi Di Yogyakarta, Maluku Utara, dan Gorontalo menempati tiga urutan teratas untuk nilai tertinggi survei ini. 


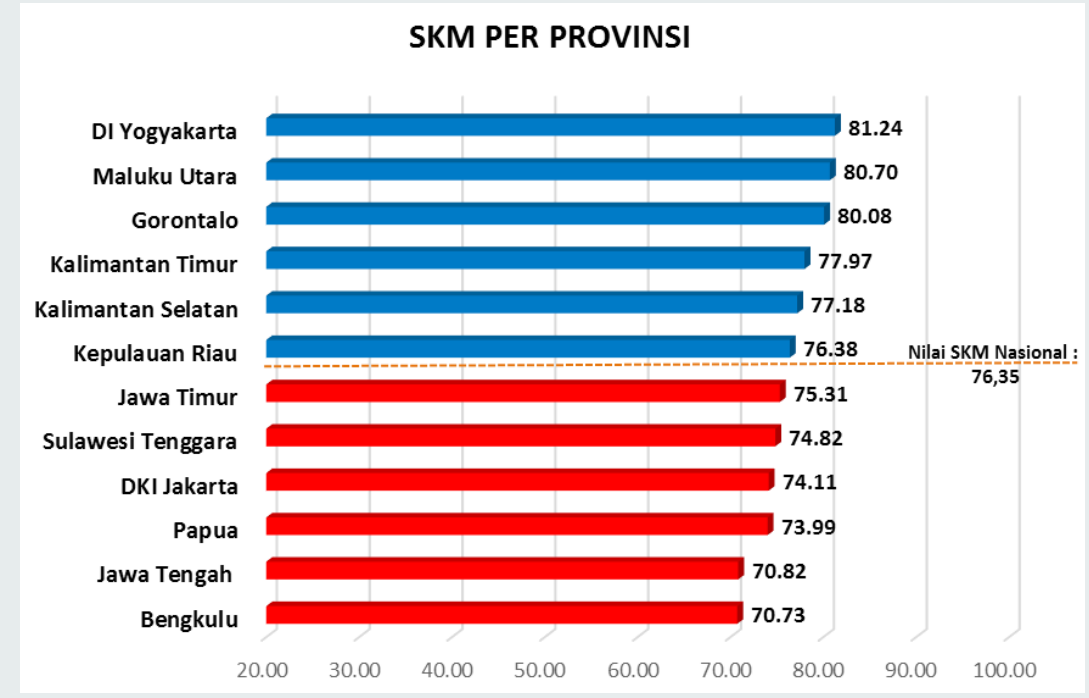

Gambar 4.8. Nilai SKM Menurut Provinsi

\subsubsection{Nilai SKM menurut Kabupaten/Kota}

Survei kepuasan Masyarakat dilakukan di 24 kabupaten maupun kota sebagai sampel. Hasil pengukuran survei menunjukaan bahwa $45,8 \%$ Kantor Pertanahan sampel masih memiliki nilai SKM di bawah rata-rata nasional yang berada pada nilai 76,35, dengan sebaran banyak Kantor Pertanahan yang berada di Pulau Jawa yaitu Kantor Pertanahan Kota Surabaya, Jakarta Utara, Sidoarjo, dan Kota Semarang. Berdasarkan data hasil pengolahan juga diketahui lokasi sampel yang memiliki nilai terbaik adalah Kantor Pertanahan Kota Yogyakarta dengan nilai 83,73, kemudian diikuti Kantor Pertanahan Kota Ternate sebesar 82,89, dan Kantor Pertanahan Kabupaten Sleman dengan nilai 80,17. Ketiga Kantor Pertanahan yang menempati uturan tiga besar tersebut memiliki komitmen tinggi memberikan pelayanan terhadap masyarakat sesuai dengan Standar Operasional Prosedur (SOP) yang sudah ditentukan. Ada sebelas Kantor Pertanahan yang mempunyai nilai SKM di bawah nilai SKM nasional $(76,35)$, antara lain Kota Surabaya, Kabupaten Banjar, Kota Tanjung Pinang, Kota Jakarta Utara, Kabupaten Sidoarjo, Kota Kendari, Kabupaten Gorontalo, dan Kota Bengkulu. Nilai SKM terendah ditempati Kantor Pertanahan Kota Semarang $(66,20)$, Kabupaten Bengkulu Tengah $(69,67)$, dan Kota Jayapura $(70,05)$. 


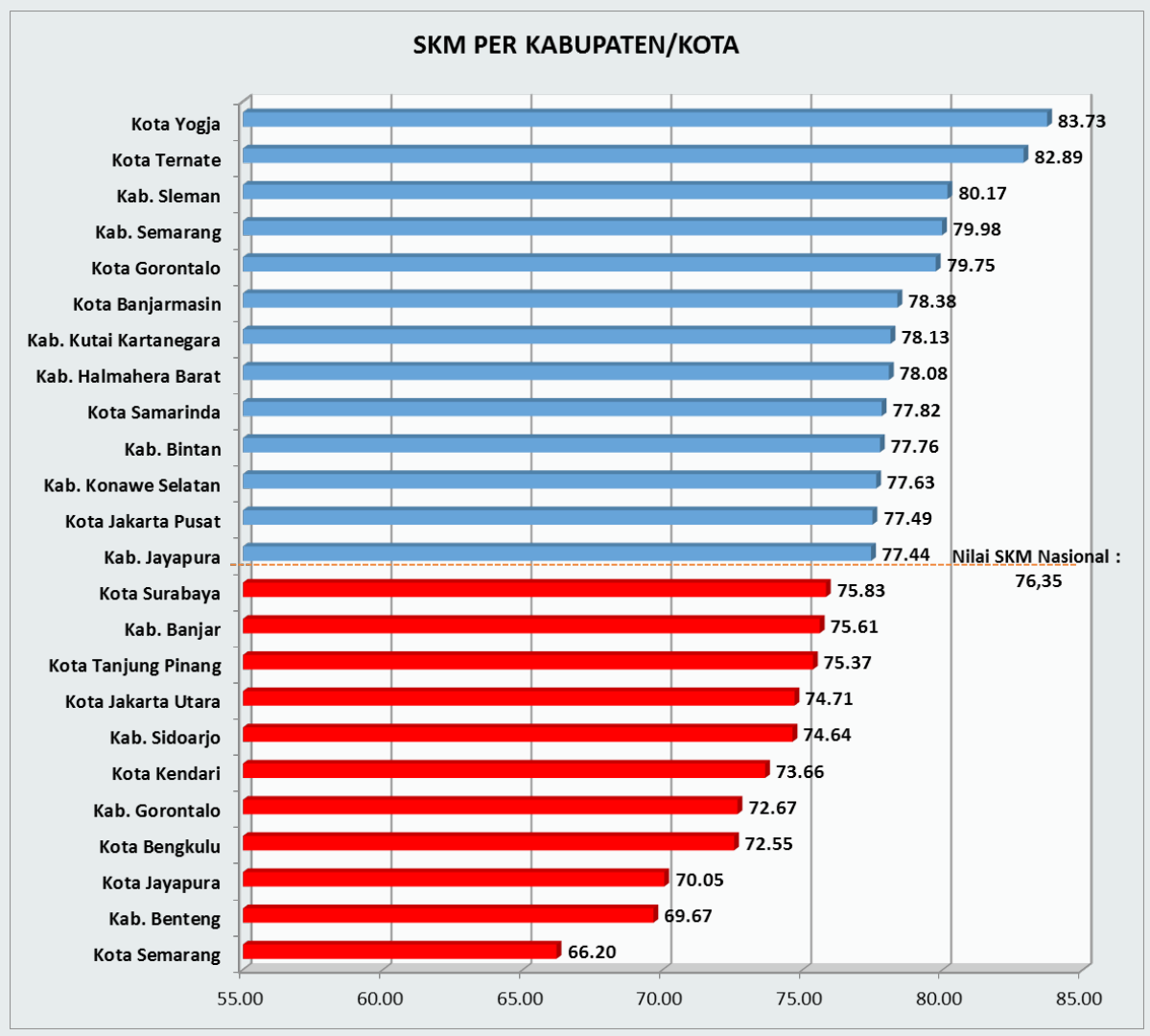

Gambar 4.9. Nilai SKM Menurut Kabupaten/Kota

\subsubsection{Nilai SKM menurut Unsur Pelayanan}

Gambaran hasil Survei Kepuasan Masyarakat jika dilihat dari sembilan unsur pelayanan akan memberikan informasi lebih detail terhadap kekurangan dan kelebihan yang dimiliki oleh penyelia layanan pertanahan. Berdasarkan penilaian masyarakat yang menjadi sampel sebanyak 1.743 responden dapat dijabarkan bahwa unsur pelayanan yang masih banyak memiliki kekurangan dengan nilai di bawah 3 (satuan mutu pelayanan 1 sampai 4) antara lain:

1. Waktu Pelayanan

2. Sarana dan Prasarana

3. Prosedur

Nilai terendah berupa waktu pelayanan $(70,62)$ sering dikeluhkan oleh masyarakat karena antara saat penyerahan berkas melalui loket hingga produk yang sudah selesai dan dapat diambil, lebih banyak tidak sesuai standar waktu yang ditentukan. Hal ini menjadi keluhan masyarakat dan membuat masyarakat menjadi kurang simpatik terhadap pelayanan Kantor Pertanahan karena dianggap tidak mampu menyelesaikan pekerjaan sesuai dengan jangka waktu yang sudah ditentukan dalam peraturan. Kondisi penilaian masyarakat ini apabila diurai lebih lanjut dengan melihat ke dalam Kantor Pertanahan akan ditemukan keterbatasan yang membuat pelayanan menjadi tidak tepat waktu sesuai SOP. Beberapa kendala yang

\section{Pusat Penelitian dan Pengembangan}


cukup sering ditemukan diantaranya adalah kesigapan petugas untuk segera memproses permohonan, jumlah permohonan yang melebihi kemampuan untuk diselesaikan hingga ketersediaan sarana dan prasarana atau peralatan teknis pendukung.

Sarana dan Prasarana merupakan unsur pelayanan terendah kedua setelah waktu pelayanan $(72,18)$. Unsur ini merupakan unsur yang baru setelah ditetapkannya Peraturan Menteri Pendayagunaan Aparatur Negara dan Reformasi Birokrasi Nomor 16 Tahun 2014 yang menggantikan unsur pelayanan Maklumat. Masyarakat umumnya menilai sarana dan prasarana yang dimiliki oleh Kantor Pertanahan masih minim. Peralatan teknis untuk kegiatan pengukuran misalnya masih terbatas dengan jumlah yang ada, sehingga hal ini berpengaruh terhadap waktu penyelesaian kegiatan pertanahan. Ketersediaan prasarana ruang tunggu yang masih terbatas sering dikeluhkan masyarakat pada jam-jam sibuk kantor sehingga banyak pengguna menunggu antrian dengan berdiri. Beberapa Kantor Pertanahan juga memiliki kekurangan dalam hal tempat ibadah dan toilet yang dapat dimanfaatkan oleh masyarakat.

Nilai terendah ketiga secara nasional berupa unsur Prosedur $(76,33)$ yaitu tata cara pelayanan yang dibakukan bagi pemberi dan penerima pelayanan khususnya di Kantor Pertanahan banyak belum dipahami masyarakat. Masyarakat tanpa kuasa yang datang ke Kantor Pertanahan umumnya belum memiliki banyak pengalaman dan pengetahuan yang cukup dalam mengurus sertipikat maupun jenis pelayanan lain yang ada di kantor tersebut sehingga sering merasa kebingungan. Sebagai akibat dari kondisi tersebut akan menjadikan masyarakat tidak cukup sekali datang ke Kantor Pertanahan melainkan berulang-ulang. Kurang pahamnya masyarakat terhadap alur prosedur menjadikan peluang bagi oknum yang tidak bertanggung jawab untuk memperoleh keuntungan dengan menawarkan sebagai jasa penerima kuasa. Jasa tersebut tidak memiliki tarif yang standar dan sulit dipantau yang mengakibatkan tarif pertanahan seolah menjadi sangat besar. Kegiatan sosialisasi layanan pertanahan sangat dibutuhkan masyarakat dengan memberikan informasi seluas-luasnya sehingga masyarakat yang tadinya kurang terbuka akan informasi pertanahan menjadi lebih paham dan berani untuk mengurus sendiri kepentingannya ke Kantor Pertanahan. Penilaian 9 unsur pelayanan secara Nasional dapat dilihat pada gambar 4.10.

Nilai SKM Per Unsur

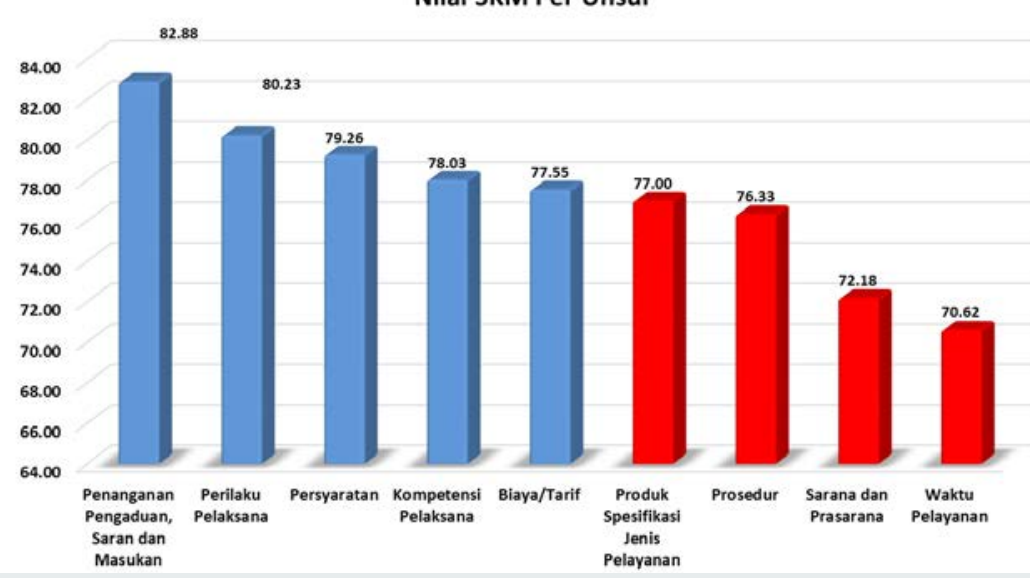

Gambar 4.10. Nilai SKM Per Unsur Pelayanan 


\section{Persyaratan}

Salah satu unsur pelayanan yang dinilai oleh masyarakat pengguna layanan pertanahan adalah persyaratan. Persyaratan dimaksud sebagai syarat yang harus dipenuhi dalam pengurusan suatu jenis pelayanan, baik persyaratan teknis maupun administratif. Berdasarkan hasil survei yang dilakukan pada 12 provinsi sampel, diketahui bahwa unsur persyaratan memiliki nilai rata-rata sebesar 79,26. Angka ini menunjukkan kategori baik. Hal yang menarik dari sebaran wilayah yang memiliki penilaian baik $(\geq 76,61)$ oleh masyarakat, terdapat pada 10 provinsi sampel. Adapun untuk 2 lokasi sampel lainnya masih dibawah angka kategori baik.

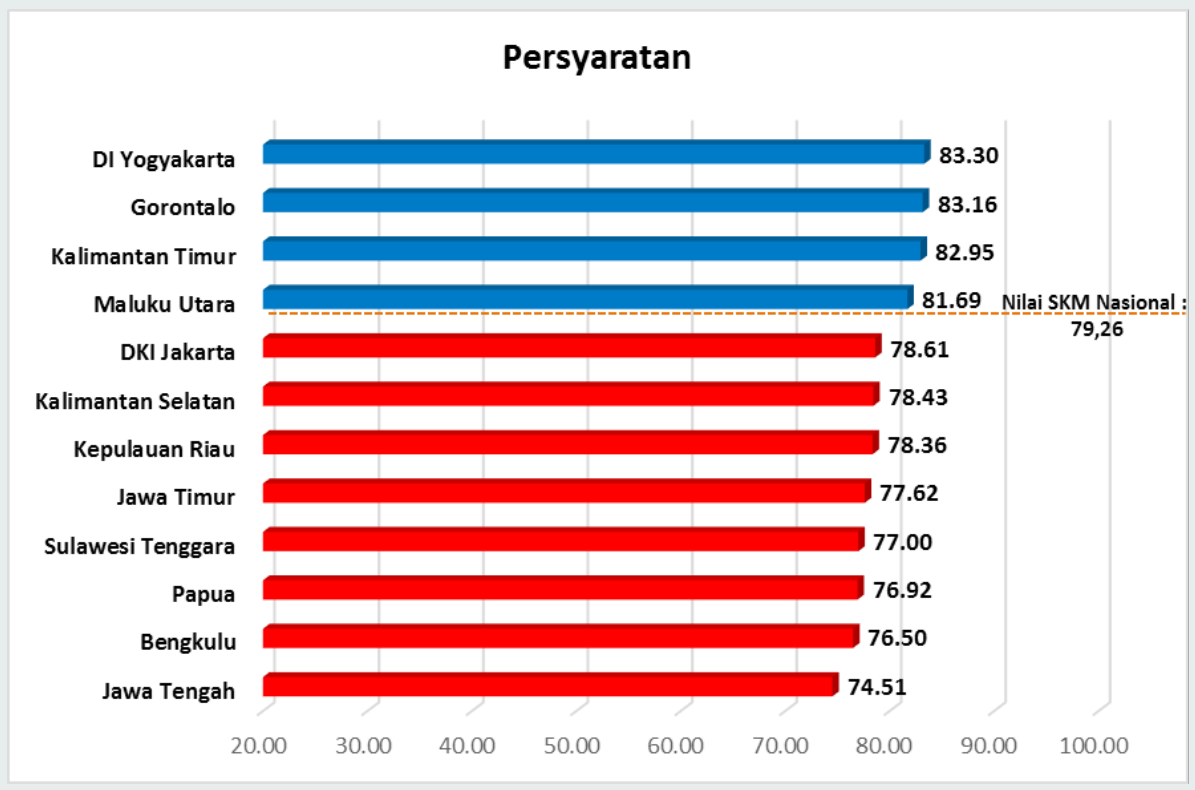

Gambar 4.11. Nilai SKM Menurut Unsur Pelayanan Persyaratan

\section{Pusat Penelitian dan Pengembangan}




\section{Prosedur pelayanan}

Unsur berikutnya yang dinilai dalam survei kepuasan masyarakat adalah tentang prosedur. Prosedur merupakan tata cara pelayanan yang dibakukan bagi pemberi dan penerima pelayanan, termasuk pengaduan. Berdasarkan hasil survei yang dilakukan pada 12 provinsi sampel, diketahui bahwa unsur persyaratan memiliki nilai rata-rata sebesar 76,33. Angka ini masih masuk kedalam kategori kurang baik. Dari 12 provinsi sampel, 7 lokasi masih berada dibawah nilai standar baik. Lebih dominannya hasil penilaian dibawah angka baik menunjukkan masih belum mudahnya masyarakat mengikuti tata cara yang sudah dibakukan tersebut, sehingga pelu ditinjau kembali mengenai kondisi prosedur yang ada dalam pelayanan kantor.

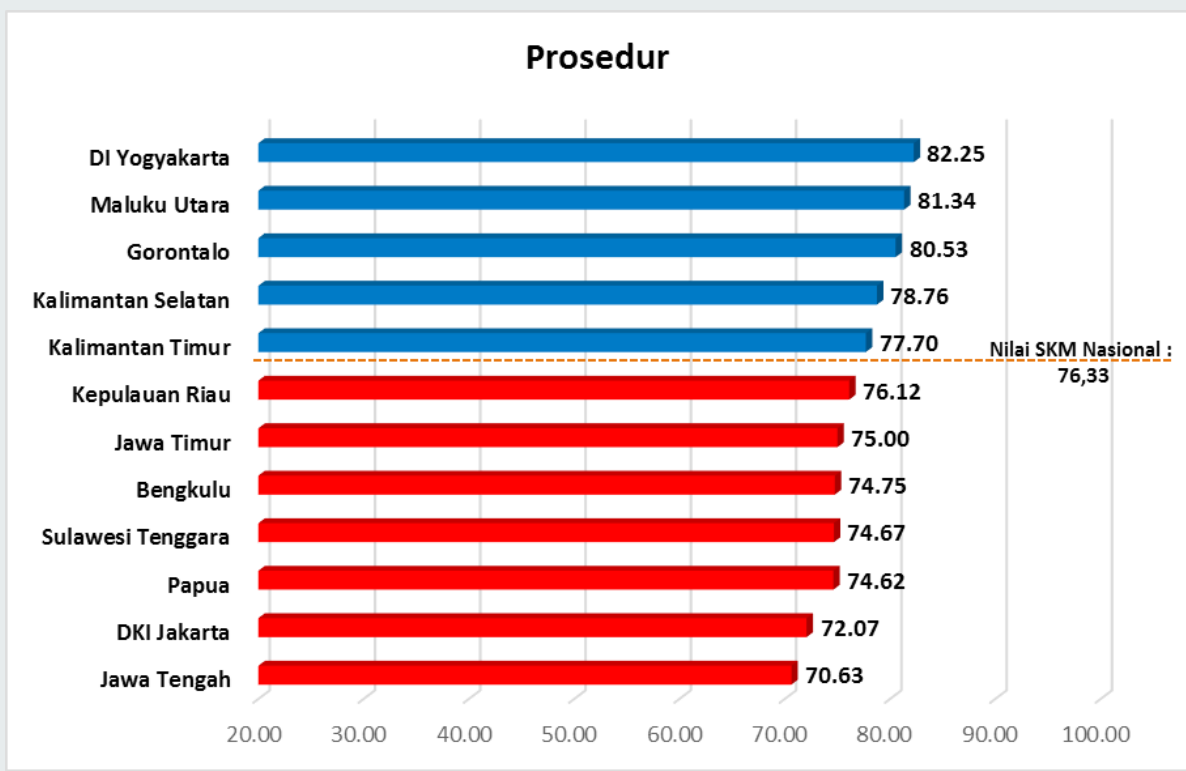

Gambar 4.12. Nilai SKM Menurut Unsur Prosedur 


\section{Waktu pelayanan}

Unsur pelayanan selanjutnya adalah waktu pelayanan. Pengertian waktu pelayanan pada survei ini adalah jangka waktu yang diperlukan untuk menyelesaikan seluruh proses pelayanan dari setiap jenis pelayanan. Perlu diketahui bahwa seluruh jenis pelayanan pertanahan memiliki batasan waktu yang sudah ditentukan, sehingga setiap ada masyarakat yang mengakses jenis layanan tertentu diharapkan sesuai dengan batasan waktu yang sudah ditentukan. Dari hasil survei, nilai rata-rata hanya mencapai 70,62. Angka ini menunjukkan masih jauh dari kata baik. Dari 12 lokasi sampel, hanya 2 lokasi ang memiliki nilai hasil survei menunjukkan baik, yaitu Provinsi Maluku Utara dan Daerah Istimewa Yogyakarta. Masih dominannya nilai pada kategori kurang baik perlu menjadi perhatian serius, mengingat penilaian masyarakat merupakan cerminan realita dan keinginan yang menjadi harapan. Untuk itu, perlu ada upaya lebih dari lembaga agar ada perbaikan. Banyak hal yang barangkali ikut menjadikan suatu pelayanan bisa tidak sesuai dengan waktu yang ditentukan. Untuk itu perlu "membedah" lebih dalam dengan menyisir setiap tahapan dan melakukan analisis penyelesaian melalui rumusan strategi pencapaian.

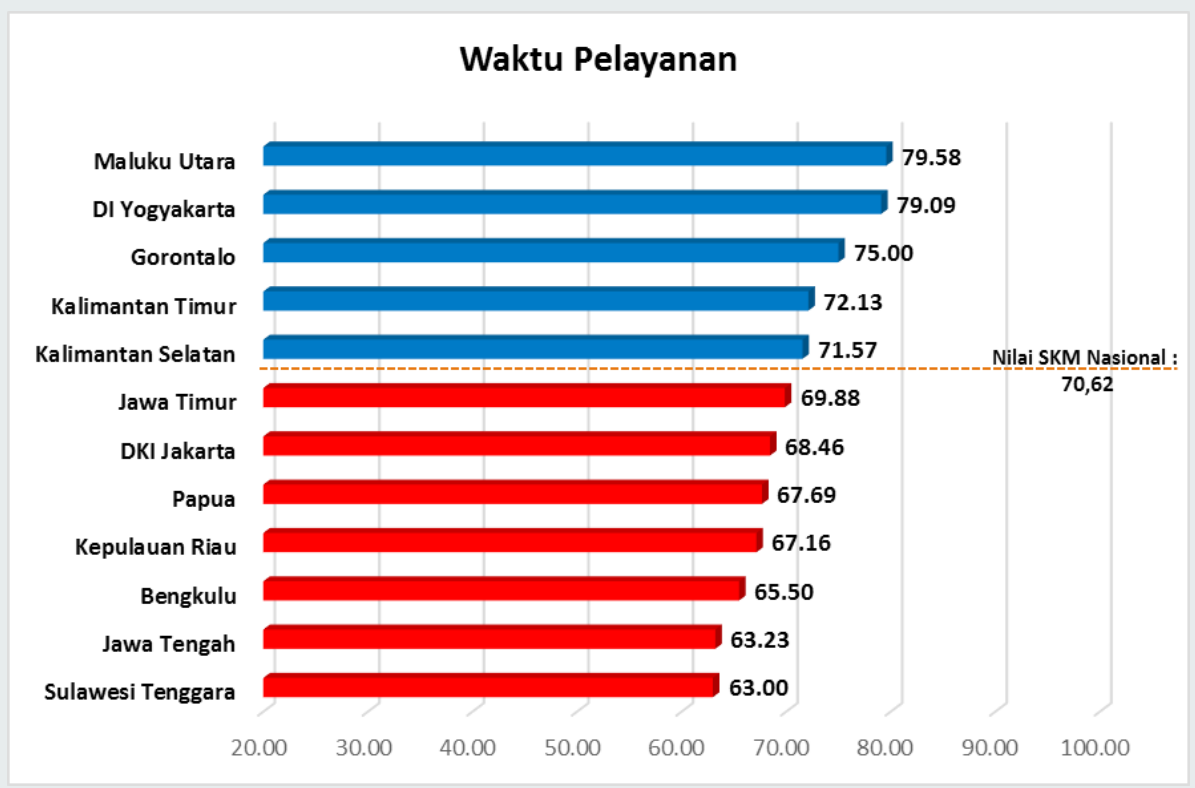

Gambar 4.13. Nilai SKM Menurut Unsur Waktu Pelayanan 


\section{Biaya/Tarif}

Biaya/tarif dalam pelayanan pertanahan sudah memiliki ketentuan baku. Pengaturannya juga sudah jelas, kewajiban dari pemohon untuk membayar Pendapatan Nasional Bukan Pajak (PNBP) sudah ditetapkan dan terinci. Namun begitu, terdapat hal-hal di luar ketentuan resmi yang terkadang masih dibebankan oleh pemohon. Bahkan aturan-aturan yang masih samar bisa menjadi celah untuk melakukan perbuatan penarikan biaya di luar kewajaran. Dari hasil survei SKM, setidaknya terdapat 8 provinsi sampel yang nilainya sudah baik. Namun begitu terdapat provinsi yang belum mencapai kriteria, bahkan cenderung banyak keluhan.

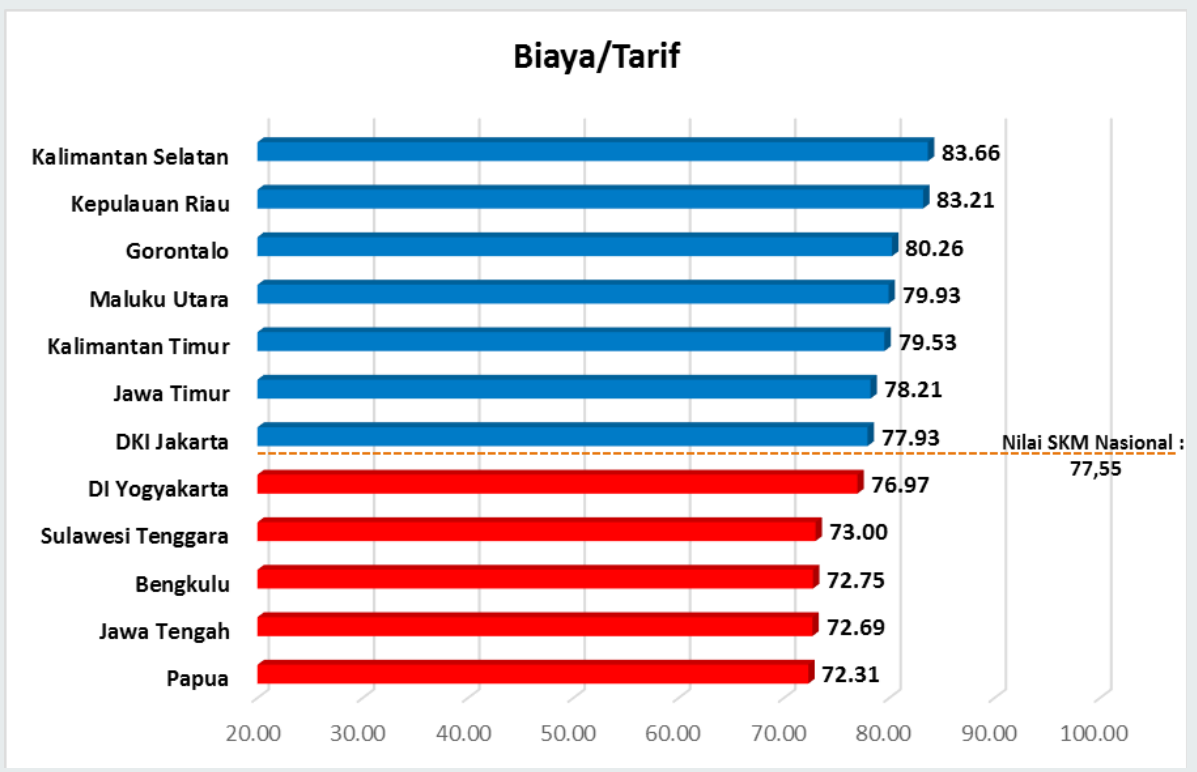

Gambar 4.14. Nilai SKM Menurut Unsur Biaya/Tarif 


\section{Produk spesifikasi jenis pelayanan}

Unsur pelayanan yang dinilai oleh masyarakat berikutnya adalah produk spesifikasi jenis pelayanan. Produk spesifikasi jenis pelayanan adalah hasil pelayanan yang diberikan dan diterima sesuai dengan ketentuan yang telah ditetapkan. Jika melihat produk/hasil pelayanan pertanahan, dapat dikatakan sedikit yang bermasalah. Produk pertanahan sudah memiliki standar baku dengan ketentuan pengaturan yang jelas. Namun begitu tidak bisa dipungkiri potensi ketidaktepatan bisa terjadi, sebagai contoh penulisan nama subyek maupun lokasi obyek. Berdasarkan hasil survei, lebih dari setengah lokasi sampel memiliki kriteria bagus terkait dengan produk spesifikasi jenis pelayanan. Bahkan nilainya masuk dalam kategori baik.

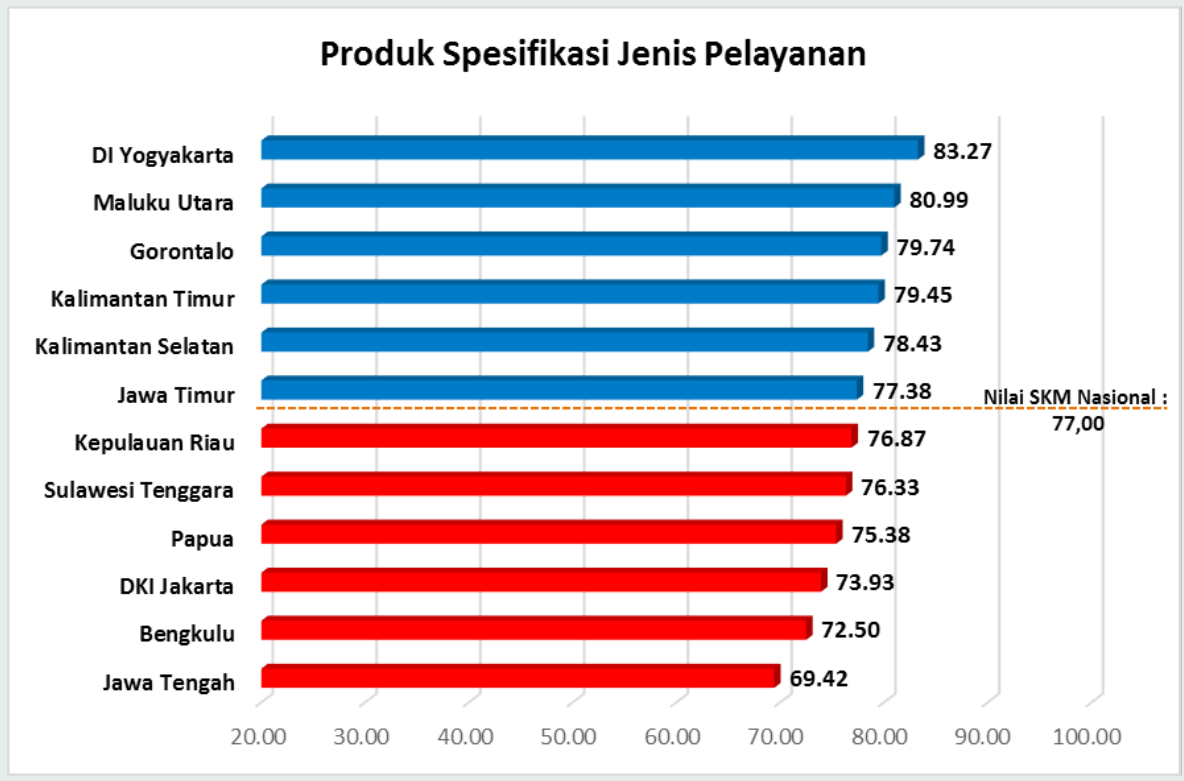

Gambar 4.15. Nilai SKM Menurut Unsur Produk Spesifikasi Jenis Pelayanan 


\section{Kompetensi pelaksana}

Unsur penilaian terhadap layanan yang diberikan lembaga pertanahan terhadap masyarakat adalah Kompetensi Pelaksana. Kompetensi Pelaksana adalah kemampuan yang harus dimiliki oleh pelaksana meliputi pengetahuan, keahlian, keterampilan, dan pengalaman. Kompetensi yang dimiliki oleh petugas sangatlah beragam, tergantung dari pengetahuan ataupun pengalaman yang dimiliki. Namun begitu, secara umum kompetensi yang dimiliki oleh petugas dapat dikatakan baik, karena nilai hasil survei menunjukkan angka 78,03. Angka ini memberikan gambaran, kemampuan petugas dalam melayani pemohon cukup memuaskan masyarakat. Namun begitu, tidak dipungkiri masih ada petugas yang kurang memiliki kompetensi dalam melaksanakan tugasnya. Baik karena kurangnya pengetahuan, keahlian, ketrampilan maupun pengalaman. Pegawai baru yang baru direkrut masih membutuhkan jam terbang mencukupi agar kemampuan penguasaan pekerjaan bisa ditingkatkan.

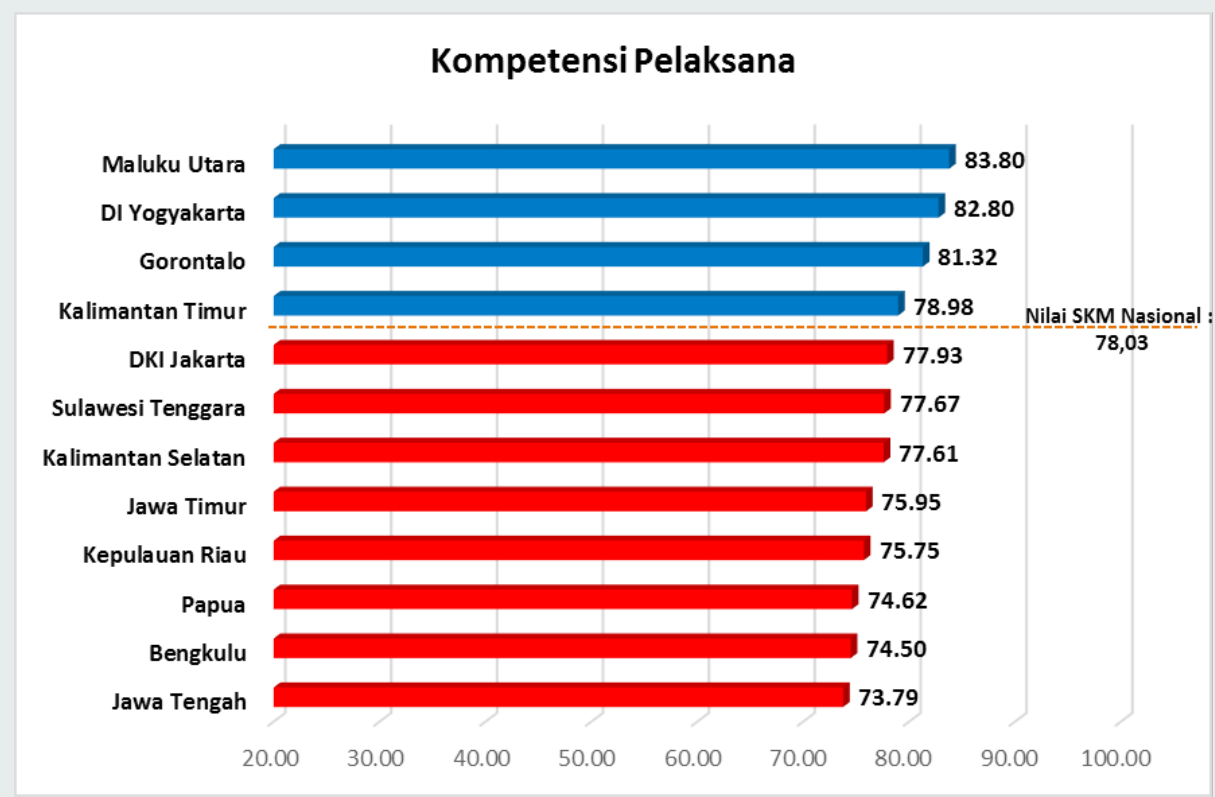

Gambar 4.16. Nilai SKM Menurut Unsur Kompetensi Pelaksana 


\section{Perilaku pelaksana}

Perilaku pelaksana berupa sikap petugas dalam memberikan pelayanan memiliki nilai yang baik, bahkan berada di atas beberapa nilai unsur lain. Secara umum dari 12 lokasi provinsi sampel, keseluruhannya berada pada kategori baik namun jika di rata-rata sudah berada pada angka 80,23 . Baiknya nilai tersebut karena sikap petugas dalam memberikan pelayanan cukup terbuka dan senang memudahkan. Meskipun tidak seluruhnya petugas bisa selalu menunjukkan hal demikian, totalitas angka hasil survei cukup menunjukkan kondisi faktual di lapangan. Sedikit petugas yang belum sepenuhnya bisa menunjukkan perilaku yang baik, bisa menjadi bahan evaluasi guna pembinaan sehingga perilaku yang ditunjukkan sudah memenuhi keinginan dari prinsip melayani.

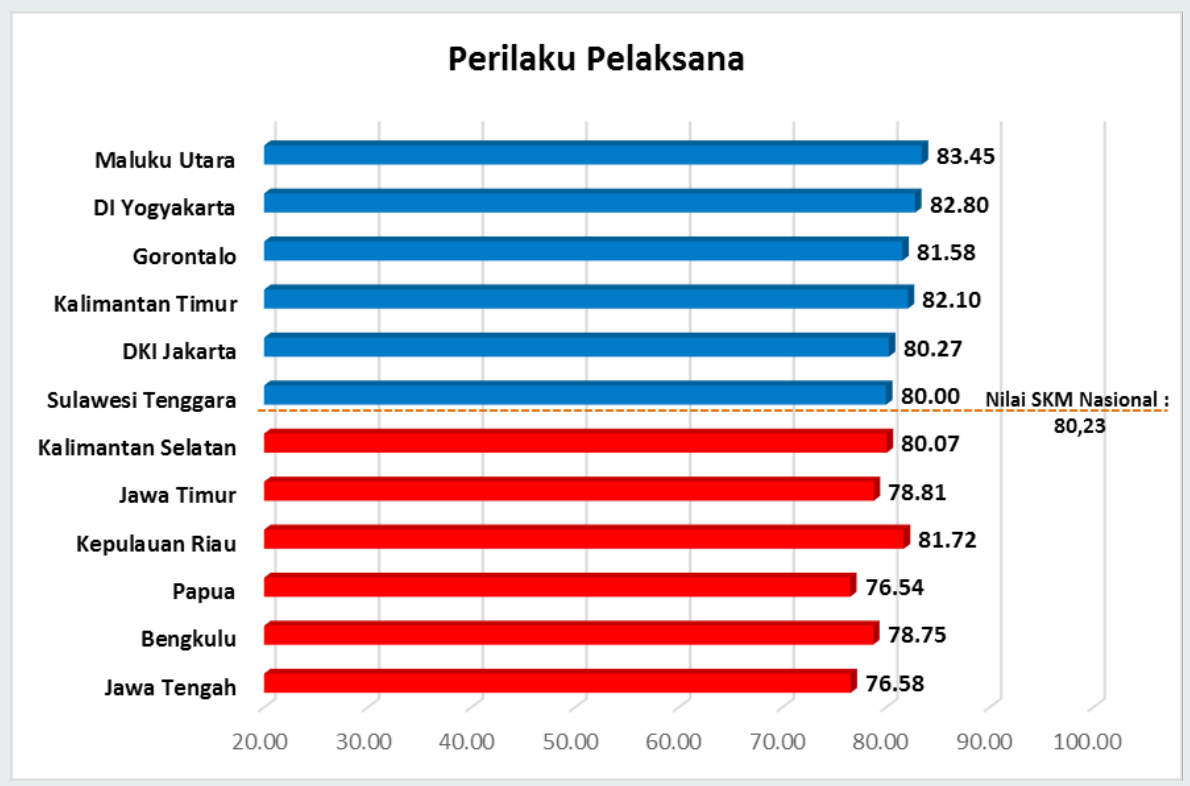

Gambar 4.17. Nilai SKM Menurut Unsur Perilaku Pelaksana 


\section{Sarana dan Prasarana}

Hal yang tidak kalah penting dalam memberikan pelayanan terhadap masyarakat adalah tersedianya sarana dan prasarana yang memadai. Di dalam unsur penilaian kepuasan masyarakat, penilaian terhadap sarana dan prasarana bisa dilakukan dari saat pemohon memasuki area kantor, di dalam loket hingga pelaksnaan kegiatan. Pengertian sarana adalah segala sesuatu yang dapat dipakai sebagai alat dalam mencapai maksud dan tujuan. Prasarana adalah segala sesuatu yang merupakan penunjang utama terselenggaranya suatu proses (usaha, pembangunan, proyek). Sarana digunakan untuk benda yang bergerak (komputer, mesin) dan prasarana untuk benda yang tidak bergerak (gedung). Berdasarkan hasil SKM, nilai sarana dan prasarana masih berada pada kategori kurang baik, karena nilainya sebesar 72,18 . Dari 12 provinsi sampel, hanya terdapat 2 lokasi yang masuk dalam kategori baik. Oleh karena itu, tinjauan terhadap sarana dan prasarana mutlak dilakukan dan disesuaikan dengan kebutuhan. Sarana dan prasarana tidak harus mewah, tetapi harus bisa membuat pengunjung nyaman dan tercipta ketertiban.

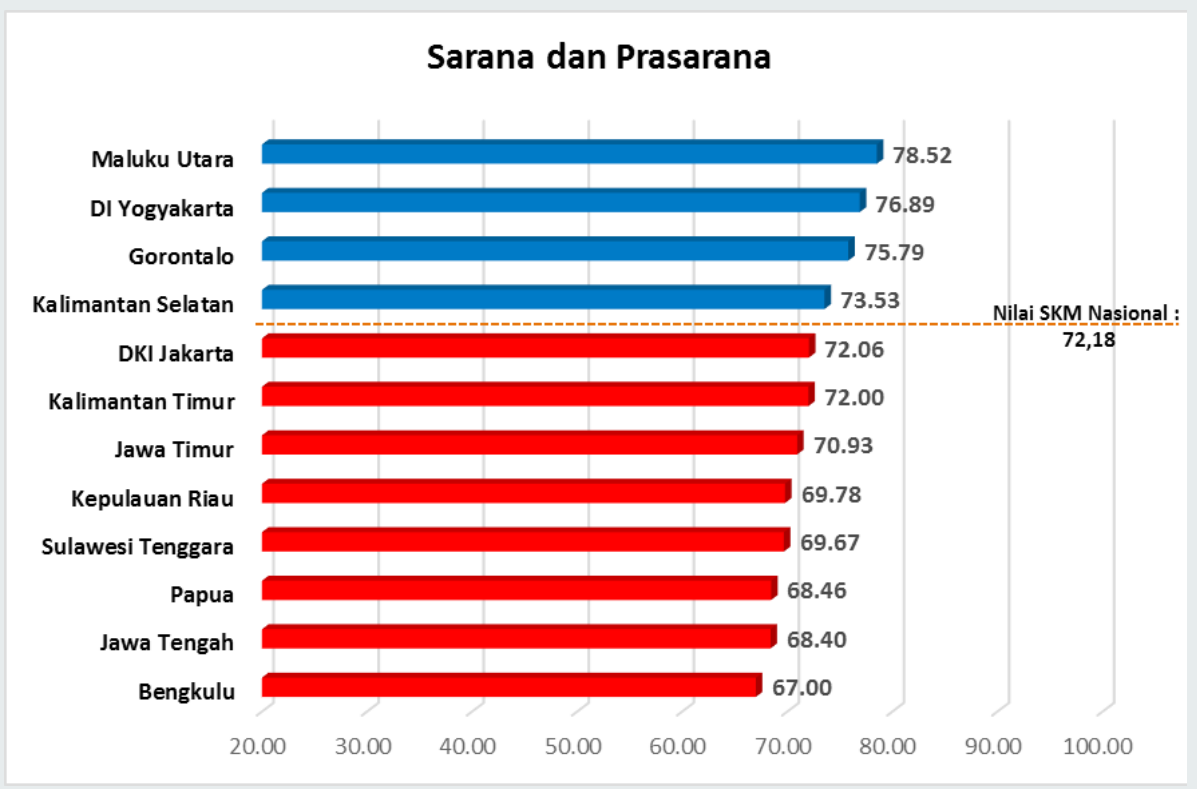

Gambar 4.18. Nilai SKM Menurut Unsur Sarana dan Prasarana 


\section{Pengaduan, saran dan masukan}

Dalam setiap kegiatan pelayanan sudah tentu bisa ditemukan ketidaksempurnaan. Selain itu dari kekurangan tersebut bisa mengakibatkan ketidakpuasan pengguna layanan yang menyebabkan munculnya pengaduan, saran dan masukan. Hampir setiap Kantor Pertanahan sudah memiliki media guna menampung pengaduan, saran dan masukan. Namun begitu, yang dibutuhkan lebih lanjut adalah respon cepat dari hal-hal yang disampaikan pengguna layanan. Penanganan pengaduan, saran dan masukan di dalam unsur survei kepuasan masyarakat pada Kantor Pertanahan, sudah memiliki nilai yang baik $(82,88)$. Hal ini bisa terwujud karena sebagian besar Kantor Pertanahan sudah melakukan aksi cepat dalam menangani pengaduan yang masuk. Dari 12 provinsi lokasi sampel, terdapat 9 provinsi sampel memiliki hasil survei masuk kategori baik. Untuk itu, nilai yang sudah baik ini perlu dipertahankan dan untuk provinsi yang masih kurang baik perlu ditingkatkan. Kunci utama bisa dikatakan baik adalah ada media serta respon cepat terhadap pengaduan, saran dan masukan.

\section{Penanganan Pengaduan, Saran dan Masukan}

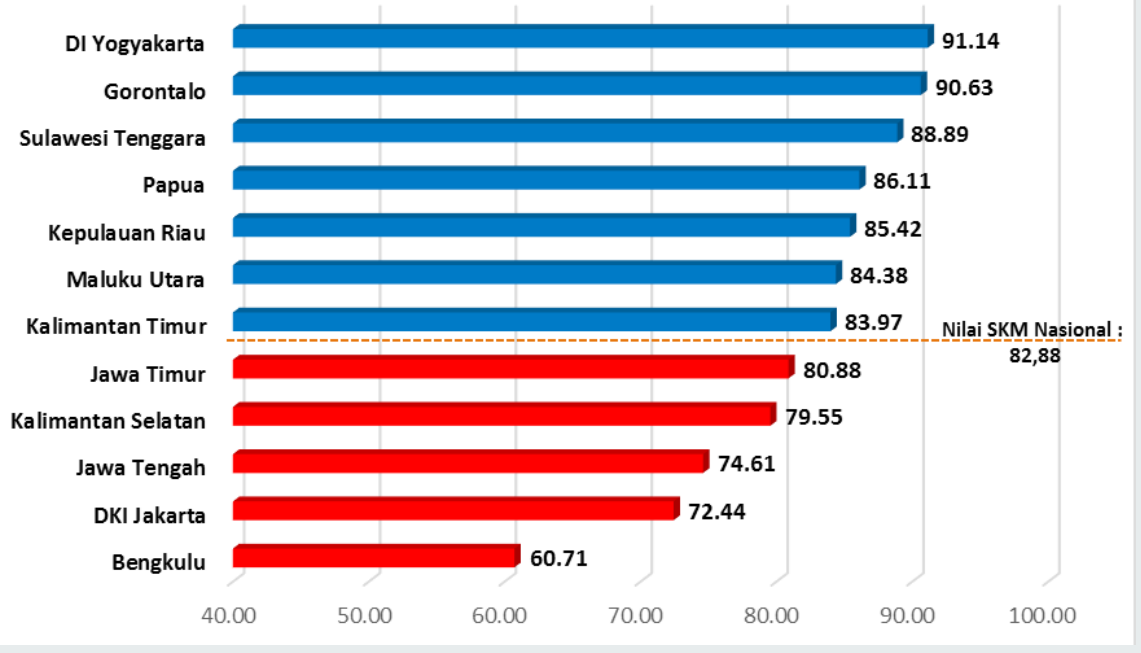

Gambar 4.19. Nilai SKM Menurut Unsur Penanganan Pengaduan, Saran dan Masukan

\subsubsection{Nilai SKM menurut Jenis Pelayanan}

Jenis pelayanan Kantor Pertanahan yang disurvei tahun 2018, hanya untuk lima pelayanan tertinggi, yaitu roya, peralihan hak, pendaftaran tanah pertama kali, pengecekan dan program strategis yang sedang berjalan PTSL (Pendaftaran Tanah Sistematis Lengkap).

Nilai SKM untuk empat jenis pelayanan berupa roya, peralihan hak, pendaftaran tanah pertama kali, pengecekan memiliki nilai kurang baik (di bawah 76,61). Sedangkan untuk PTSL, nilai yang diperoleh masuk kategori baik $(86,06)$. Berikut tersaji nilai SKM pada berbagai jenis pelayanan di Kantor Pertanahan sampel. 


\section{SKM PER JENIS PELAYANAN}

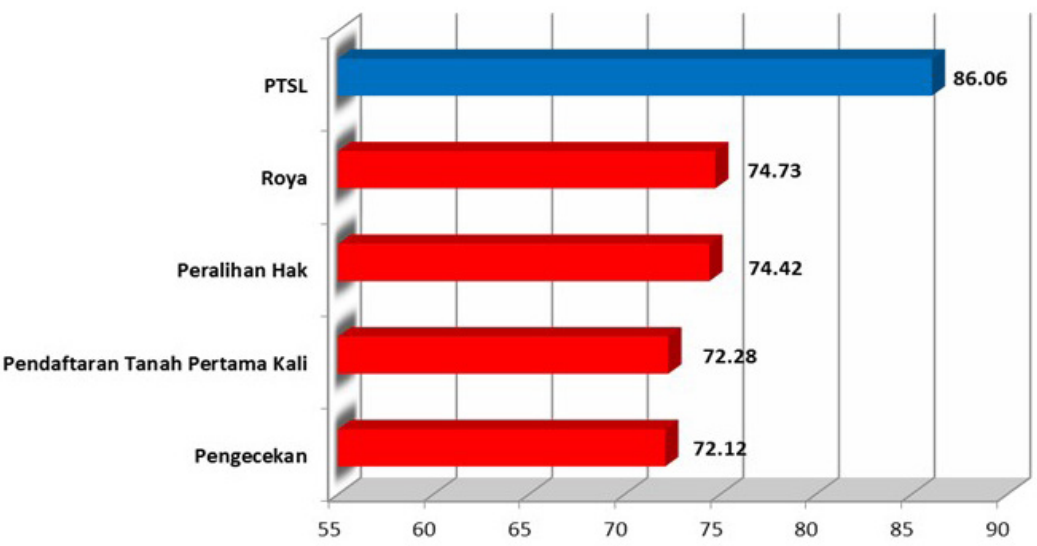

Gambar 4.20. Nilai SKM Menurut Jenis Pelayanan

\section{Pendaftaran Pertama Kali}

Pendaftaran tanah pertama kali didalam SOPP termasuk jenis pelayanan yang memiliki rentang waktu yang paling panjang dibandingkan dengan jenis pelayanan lainnya. Hal ini disebabkan oleh rangkaian/tahapan yang harus dilalui termasuk banyak dan melibatkan berbagai bidang terkait. Berdasarkan hasil survei kepuasan msyarakat yang dilakukan pada 12 provinsi sampel, hasilnya belum begitu menggembirakan. Hanya $25 \%$ provinsi yang nilainya masuk pada kategori baik, sedangkan sisanya masuk pada kategori kurang baik. Masih banyaknya kantor yang memberikan pelayanan kurang baik, khususnya bagian pendaftaran tanah pertama kali perlu mendapatkan perharian lebih serius mengingat potensi pendaftaran tanah pertama kali masih sangat banyak, terutama pada wilayah dengan status kabupaten dan berada di luar Pulau Jawa. Untuk itu diperlukan upaya lebih keras dengan merancang desain manajemen mumpuni, baik dari sisi tenaga (SDM), teknologi penunjang hingga sistem kepegawaian yang lebih sehat.

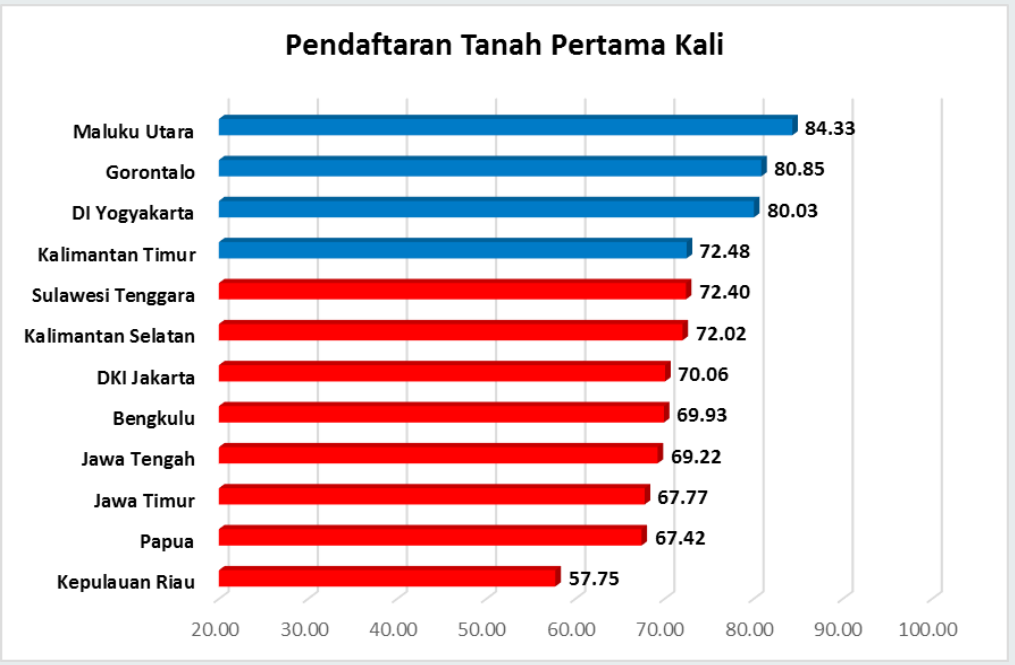

Gambar 4.21. Nilai SKM Menurut Jenis Pelayanan Pendaftaran Tanah Pertama Kali 


\section{Peralihan Hak}

Berikutnya penilaian masyarakat terhadap jenis layanan peralihan hak dapat dikatakan kurang baik, karena nilai akhir adalah 74,42 . Nilai SKM jenis pelayanan peralihan hak nasional sebesar 74,42 menurut Permenpan dan RB No. 14 Tahun 2017 menunjukkan pelayanan peralihan hak oleh Kantor Pertanahan Kabupaten dan Kota di provinsi sampel masuk dalam kategori mutu pelayanan $C$ atau dalam kategori kinerja unit pelayanan yang kurang baik. Sebagian besar provinsi sampel (67 persen) masih dalam kategori kurang baik, bahkan 58 persen berada di bawah nilai SKM jenis pelayanan peralihan hak nasional. Nilai SKM jenis pelayanan peralihan hak provinsi yang nilainya baik dan di atas nilai SKM Nasionalnya hanya 4 provinsi (33 persen) yaitu Maluku Utara, DI Yogyakarta, Gorontalo dan Kalimantan Selatan. Nilai SKM jenis pelayanan peralihan hak provinsi yang terbesar adalah Maluku Utara sebesar 80,13 termasuk mutu pelayanan B atau kinerja unit pelayanan baik.

Didalam SOPP, pelayanan peralihan hak bisa dilayani dalam jangka waktu 5 hari kerja. Adapun jenis layanan yang masuk kategori peralihan hak diantaranya adalah jual beli, pewarisan, tukar menukar, lelang dan hibah. Kenyataan di lapangan, penyelesaian (produk bisa diambil) kegiatan peralihan hak bisa lebih dari 7 hari bahkan tidak sedikit yang lebih dari itu. Untuk itu perlu tinjauan kembali dan mengkaji ulang kemampuan riil yang dimiliki oleh Kantor Pertanahan guna menyelesaikan suatu permohonan.

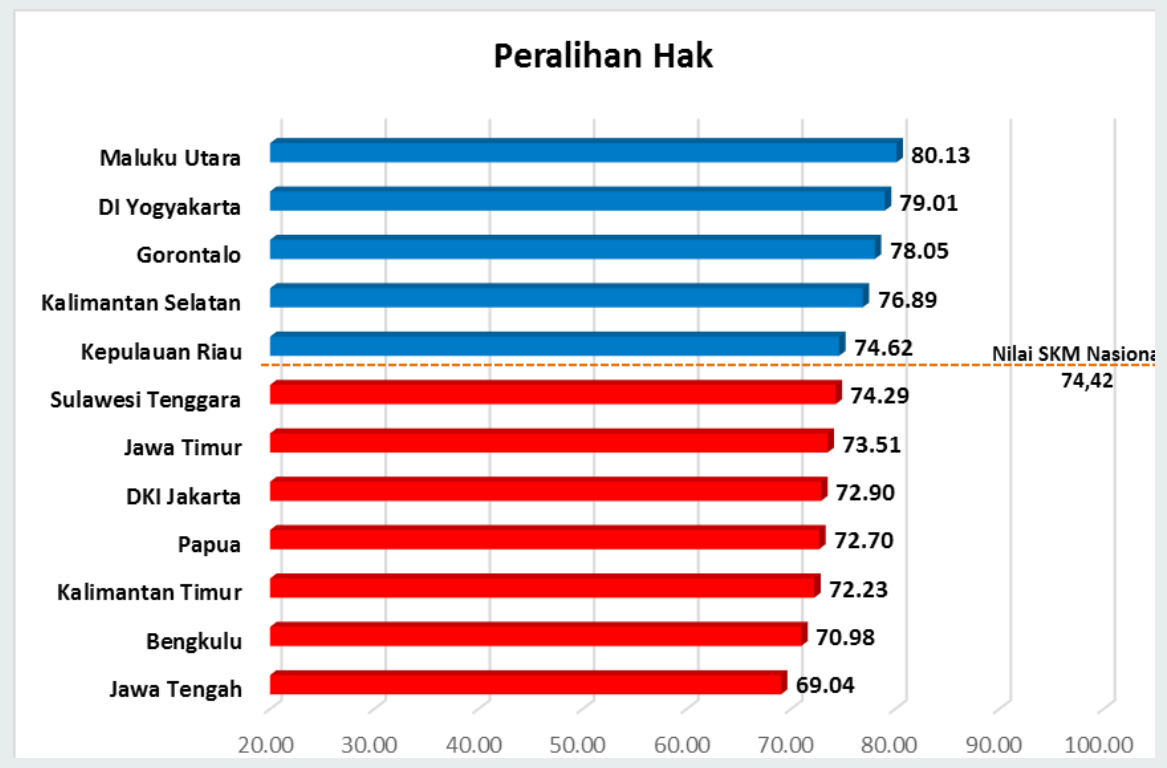

Gambar 4.22. Nilai SKM Menurut Jenis Pelayanan Peralihan Hak 


\section{Pengecekan}

Kegiatan penyelesaian permohonan pelayanan pengecekan di dalam SOPP yang sudah ditetapkan termasuk yang paling cepat dan ringan dibandingkan dengan jenis pelayanan lainnya. Berdasarkan ketentuan, layanan pengecekan bisa diselesaikan dalam jangka waktu 1 hari kerja. Namun begitu, tidak semua Kantor Pertanahan bisa memenuhi ketentuan tersebut dengan berbagai alasan. Nilai survei kepuasan masyarakat terhadap layanan Pengecekan, termasuk dalam kategori Kurang Baik $(72,12)$. Hal ini cukup ironi mengingat pekerjaan yang bisa diselesaikan dalam waktu cepat dan tidak terlalu membutuhkan tenaga lebih keras ternyata masih jauh dari harapan. Hanya $33,33 \%$ provinsi sampel yang nilainya masuk kategori Baik. Sisanya masuk pada kategori Kurang Baik. Berdasarkan informasi dari petugas, penyelesaian pekerjaan pengecekan bisa lebih dari satu hari bisa disebabkan karena beberapa hal. Diantaranya adalah infrastruktur/manajemen buku tanah/warkah yang masih kurang baik, sistem bekerja yang kurang terintegrasi untuk segera bisa direspon dan tidak adanya pejabat berwenang yang melegalisasi (dinas luar).

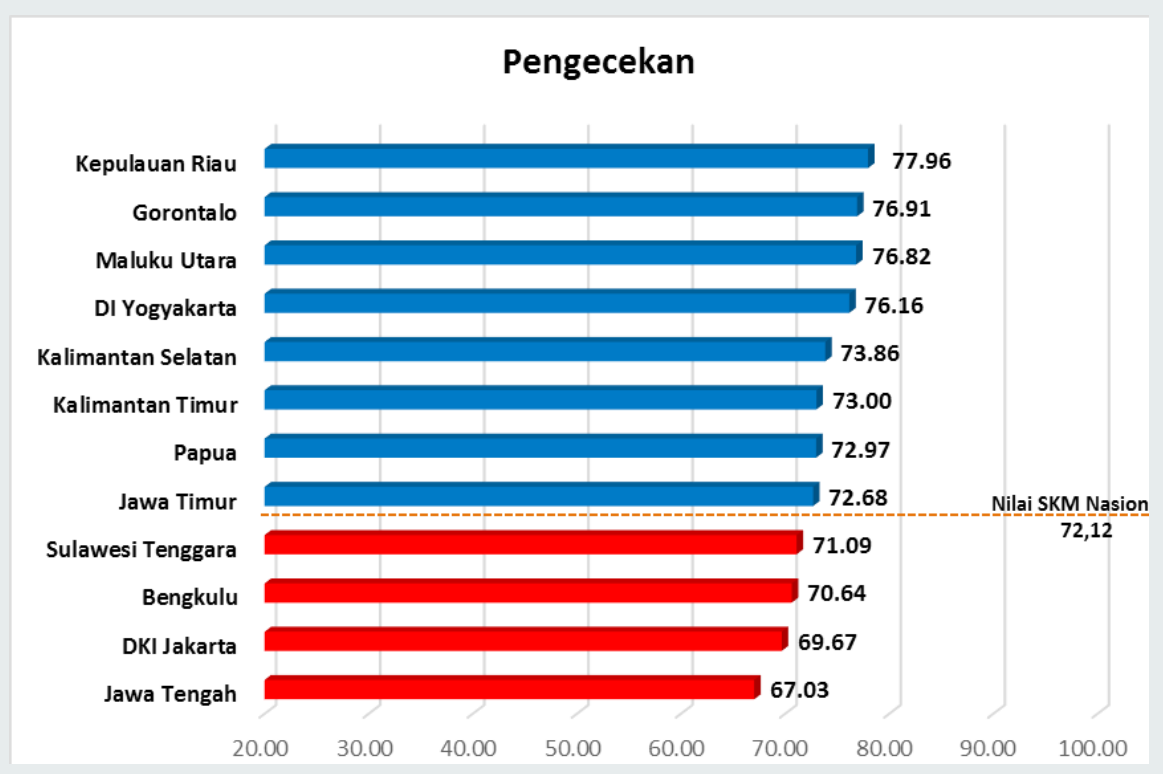

Gambar 4.23. Nilai SKM Menurut Jenis Pelayanan Pengecekan 


\section{Roya}

Nilai SKM jenis pelayanan Roya nasional sebesar 74,73, menurut Permenpan dan RB No. 14 Tahun 2017 menunjukkan pelayanan Roya oleh Kantor Pertanahan Kabupaten dan Kota di provinsi sampel masuk dalam kategori mutu pelayanan $C$ atau dalam kategori kinerja unit pelayanan yang kurang baik. Sebagian besar provinsi sampel ( 83 persen) masih dalam kategori kurang baik, bahkan 58 persen berada di bawah nilai SKM jenis pelayanan Roya Nasional. Nilai SKM jenis pelayanan Roya provinsi yang nilainya baik dan di atas nilai SKM Nasionalnya hanya 2 provinsi (17 persen) yaitu DI Yogyakarta dan Kalimantan Timur. Nilai SKM jenis pelayanan Roya provinsi yang terbesar adalah DI Yogyakarta sebesar 83,01 termasuk mutu pelayanan B atau kinerja unit pelayanan baik.

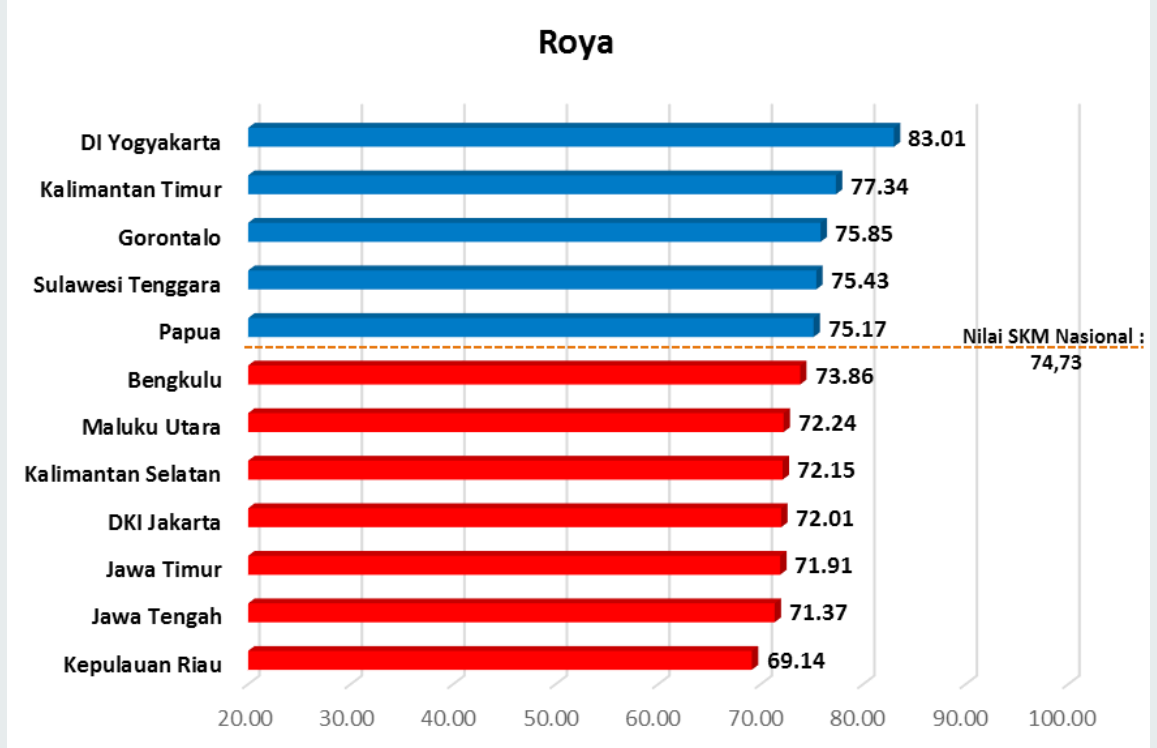

Gambar 4.24. Nilai SKM Menurut Jenis Pelayanan Roya 


\section{Pendaftaran Tanah Sistematis Lengkap (PTSL)}

Karena PTSL merupakan program strategis di kementerian ATR/BPN dimana target yang harus dilaksanakan juga meningkat secara signifikan, maka pada tahun ini kami mensurvei untuk mengetahui animo dan respon masyarakat terhadap layanan ini pada 12 provinsi dan 24 Kantor Pertanahan.

Nilai SKM untuk jenis pelayanan PTSL rata-rata sebesar 86,06 berarti masuk dalam kategori baik. Dari angka rata-rata tersebut, ada enam provinsi memiliki nilai di atas rata-rata, yaitu DKI Jakarta, Kalimantan Timur, Jawa Tengah, Maluku Utara, Jawa Timur dan DI Yogyakarta. Untuk provinsi yang nilai nya di bawah rata-rata namun masih masuk dalam kategori baik adalah Gorontalo, Papua, kepulauan Riau dan Sulawesi Tenggara. Sedangkan provinsi yang nilainya masuk dalam kategori kurang baik adalah Bengkulu dan Kalimantan Selatan.

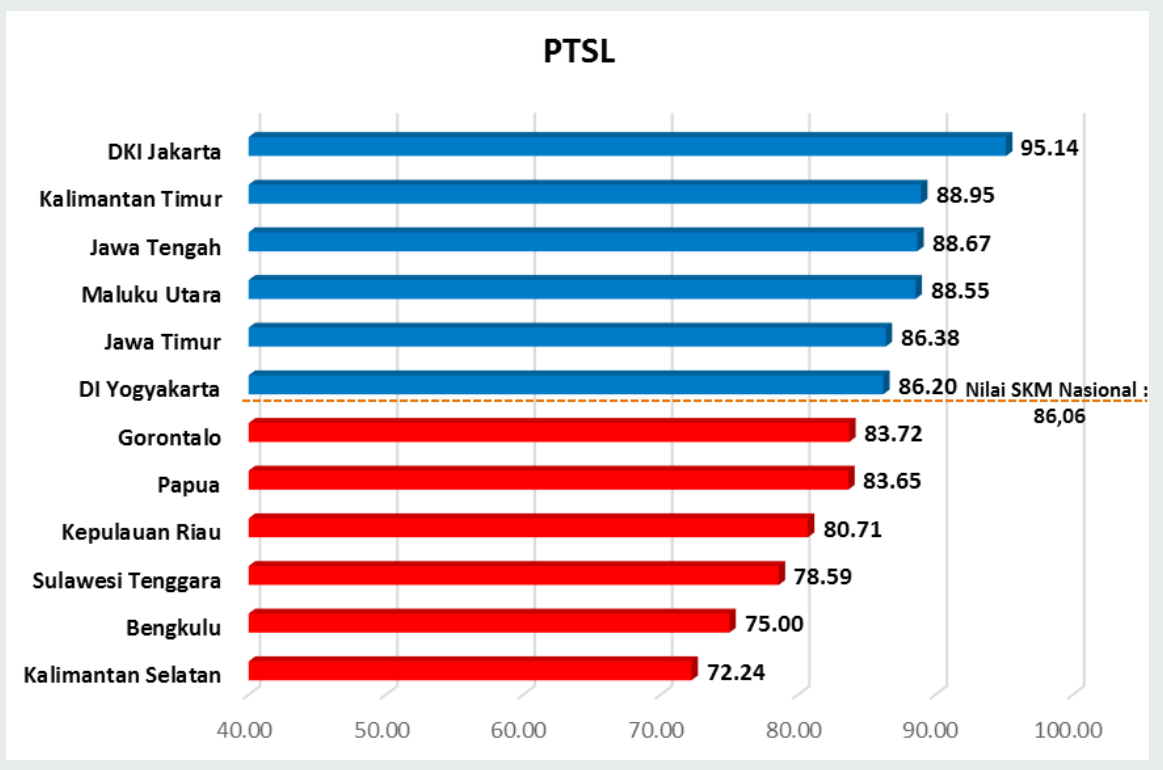

Gambar 4.25. Nilai SKM Menurut Jenis Pelayanan PTSL 


\section{Nilai SKM Per Jenis Layanan PTSL dan Non PTSL}

Pendaftaran Tanah Sistematis Lengkap adalah kegiatan pendaftaran tanah untuk pertama kali yang dilakukan secara serentak bagi semua obyek pendaftaran tanah di seluruh wilayah Republik Indonesia dalam satu wilayah desa/kelurahan atau nama lainnya yang setingkat dengan itu, yang meliputi pengumpulan dan penetapan kebenaran data fisik dan data yuridis mengenai satu atau beberapa obyek pendaftaran tanah untuk keperluan pendaftarannya. Melalui program ini, pemerintah memberikan jaminan kepastian hukum atau hak atas tanah yang dimiliki masyarakat. Respon masyarakat terhadap PTSL di lokasi penelitian cukup baik. Hal ini terbukti dengan nilai survei kepuasan masyarakat yang lebih tinggi dibandingkan dengan nilai pelayanan rutin pertanahan lainnya. Nilai kepuasan masyarakat untuk program PTSL sebesar 86,06 dimana nilai tersebut termasuk ke dalam kategori baik. Hasil indepth interview terhadap masyarakat yang mengikuti program PTSL menyatakan bahwa pengurusan pendaftaran tanah jauh lebih mudah dan murah karena tidak dipungut biaya. Program PTSL ini memberikan fasilitas atau kemudahan yang diberikan oleh pemerintah kepada pemegang hak atas tanah yaitu dalam pelaksanaan kegiatan PTSL untuk semua biaya, meliputi biaya pendaftaran hak, biaya pengukuran, biaya pemeriksaan tanah adalah gratis (pemohon tidak dipungut biaya) dalam hal pembiayaan dan proses penyelesaian sertifikat hak tanahnya ditanggung oleh Negara. Masyarakat menginginkan sosialisasi yang lebih intensif terkait program PTSL ini.

Berbeda halnya dengan nilai kepuasan masyarakat untuk layanan pertanahan rutin. Survei Kepuasan Masyarakat menunjukan nilai 73,19 dimana nilai tersebut masuk kedalam kategori kurang baik. Layanan pertanahan seperti pendaftaran pertama kali, peralihan hak, pengecekan, dan Roya secara keselururuhan masyarakat menilai waktu penyelesaian layanan pertanahan tersebut sangat lambat. Masuknya program PTSL kedalam penilaian SKM 2018 memberikan hasil yang positif terhadap nilai SKM secara keseluruhan. Dengan nilai SKM layanan rutin sebesar 73,19 ditambah dengan nilai SKM program PTSL 86,06 menghasilkan nilai SKM Nasional sebesar 76,35.

\section{SKM PER JENIS PELAYANAN}

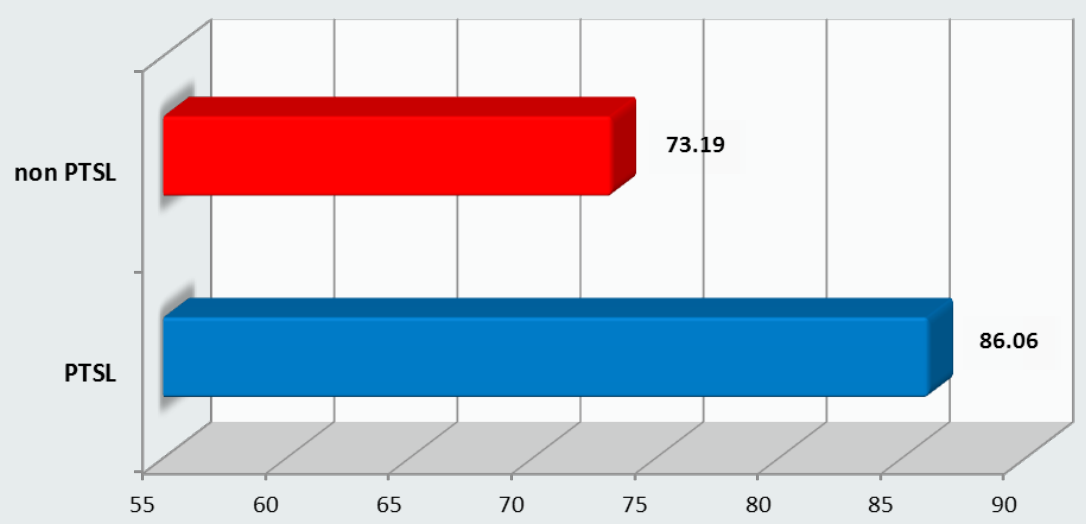

Gambar 4.26. Nilai SKM Menurut Jenis Pelayanan PTSL dan Non PTSL 
7. Nilai SKM PTSL dan Non PTSL berdasarkan unsur pelayanan

Nilai SKM untuk PTSL jauh lebih baik dari pada nilai SKM non PTSL. Nilai untuk seluruh unsur pelayanan ada di kategori baik. Tiga terendah adalah sarana dan prasarana mendapat nilai 81,10 , kemudian waktu pelayanan mendapat nilai 84,20 dan kompetensi pelaksana mendapat nilai 85,52 . Sedangkan tiga unsur pelayanan tertinggi adalah penanganan pengaduan saran dan masukan mendapat nilai 92,47, kedua unsur biaya/tarif 91,20 dan ketiga unsur prosedur pelayanan 88,16 .

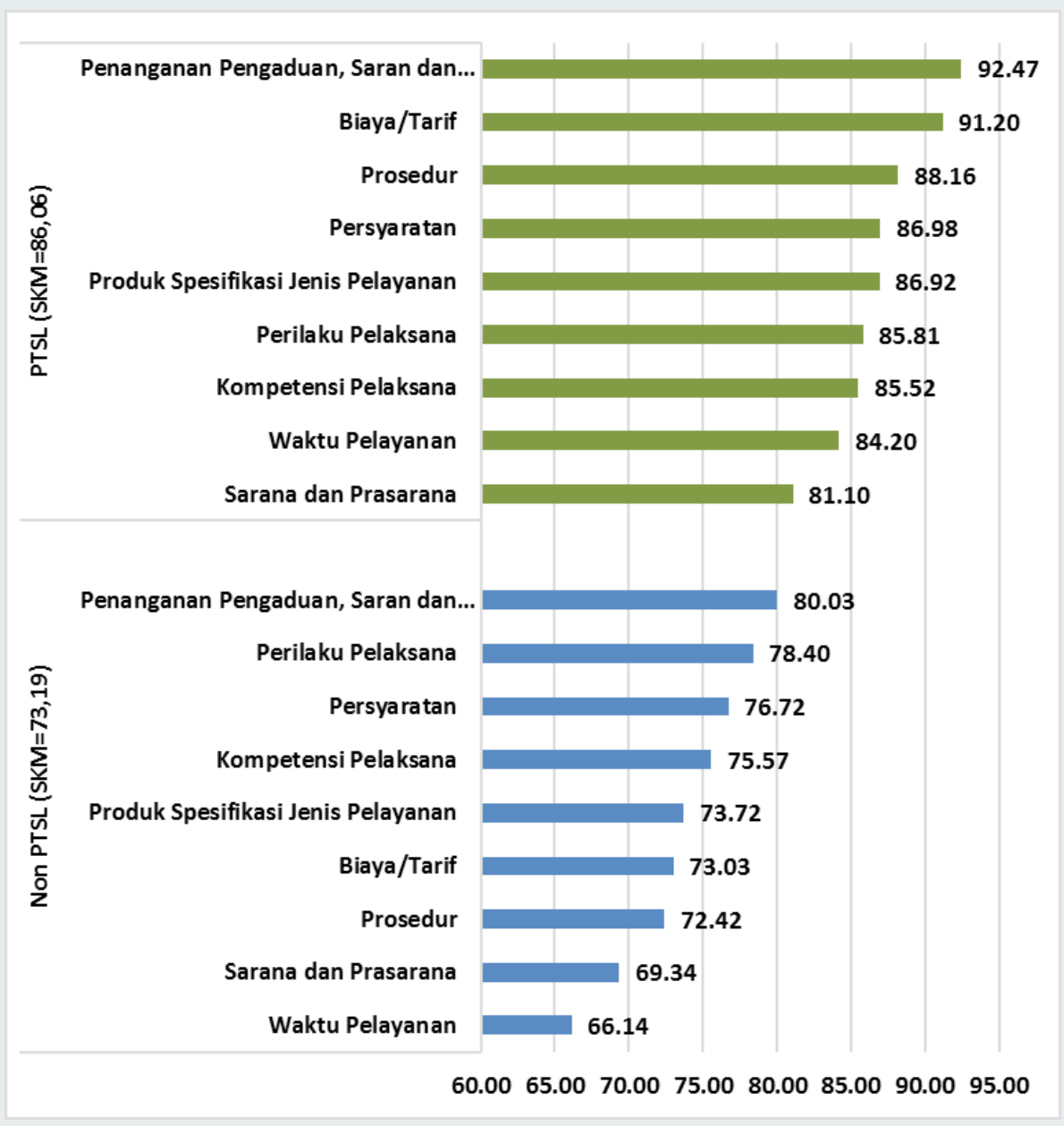

Gambar 4.27. Perbandingan Nilai SKM PTSL dan Non PTSL Berdasarkan Unsur Pelayanan

Melihat Gambat 4.27 di atas maka ada perbedaan signifikan hasil yang dirasakan oleh Kantor Pertanahan yang melakukan layanan rutin memiliki kecenderungan nilai unsur yang lebih rendah dibandingkan respon masyarakat terhadap layanan PTSL dimana nilai masing-masing unsur lebih baik. Perbandingan rata-rata layanan rutin mencapai 73,19 dan PTSL ada di kisaran 86,06 merefleksikan bahwa masyarakat yang mengakses layanan lewat PTSL, melihat dan merasakan adanya respon positif masyarakat, biaya, dan waktu penyelesaian berkas yang jauh lebih cepat dan tepat. Pengkonsentrasian segenap jajaran Kantor Pertanahan terlihat 
dari semua pegawai ASN dan PTT wajib dan pasti mendapat bagian program strategis PTSL, sementara di Layanan Rutin terkonsentrasi pada Seksi I dan Seksi II.

Pada layanan PTSL waktu penyelesaian berkas adalah satu tahun anggaran sehingga masyarakat mendapat jawaban pasti terkait kapan selesainya sertipikat tanah tersebut, yang kedua jika ada keterlambatan penyelesaian cenderung dikarenakan adanya penyerahan secara simbolis oleh presiden dengan kenyataan tersebut masyarakat sedikit menerima dengan kondisi tersebut. Fakta yang terjadi dan dirasakan seluruh tim peneliti SKM di Kantor Pertanahan memang operasional kantor memang didesain untuk menyelesaikan PTSL terlebih dahulu dibandingkan layanan rutin. Sudah dapat dipastikan bahwa segenap warga Kantor Pertanahan wajib ambil bagian dalam PTSL. Pengelolaan berkas mulai verifikasi, pemeriksaan, validasi, entry data, sampai final pun PTSL mendapat prioritas.

Layanan rutin itu bisa dikategorikan layanan derivatif yang sifatnya pembaharuan data yang tidak membutuhkan cek lapangan biasanya tidak terpengaruh sebab sifatnya hanya memperbaharui data tetapi layanan yang memerlukan cek fisik yang berakibat perubahan data signifikan biasanya akan terkena dampak penundaan sebab seluruh ASN dan PPNPN yang ada di pengukuran lebih mengutamakan layanan pengukuran PTSL. Ini konsekuensi logis mengingat periode ini penilaian kinerja kantor sangat mempertimbangkan keberhasilan PTSL menjadi salah satu parameternya.

\subsubsection{Nilai SKM Menurut Subyek Pemohon}

Nilai SKM menurut subyek pemohon memiliki perbedaan yang cukup signifikan, subyek pemohon langsung baik permohonan rutin maupun PTSL memberikan nilai 79,11 yang masuk dalam kategori baik. Sedangkan subyek pemohon kuasa/pihak ketiga mempunyai nilai 73,16 atau berada pada kategori kurang baik.

\section{Nilai SKM Per Subyek}

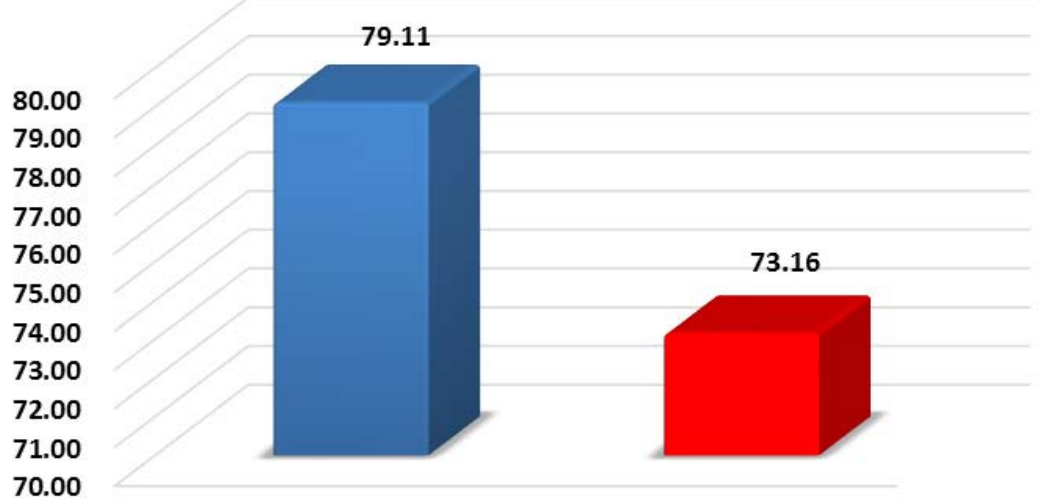




\subsubsection{Nilai SKM Menurut Wilayah Pulau Jawa dan Luar Pulau Jawa}

Pulau Jawa yang identik dengan kelengkapan infrastruktur, sarana dan prasarana termasuk yang berkaitan dengan pelayanan dianggap memiliki kelebihan dibandingkan dengan daerah luar Pulau Jawa. Hasil pengukuran melalui SKM terhadap pelayanan Kantor Pertanahan yang kemudian dikomparasikan antara Pulau Jawa dan luar Jawa, dapat diketahui rata-rata nilai SKM di Pulau Jawa adalah 75,91, sedangkan rata-rata nilai SKM di luar Pulau Jawa adalah 76,88. Dari fakta tersebut, ternyata nilai SKM di luar Pulau Jawa sedikit lebih tinggi dari nilai SKM Pulau Jawa. Kondisi ini terjadi antara lain karena tingginya volume pelayanan di pulau Jawa, seperti yang terjadi pada Kantor Pertanahan Surabaya 1, Jakarta Utara dan Kabupaten Sidoarjo. Jika dibandingkan dengan Kantor Pertanahan kota Ternate, mempunyai nilai SKM tinggi, didukung dengan sarana yang bagus, pelayanan juga bagus, namun volume permohonan pelayanan hanya sekitar 6.559 berkas per tahun, sangat jauh berbeda dengan volume permohonan pelayanan di kota Jakarta Utara yang bisa mencapai 6.000 berkas per bulan.

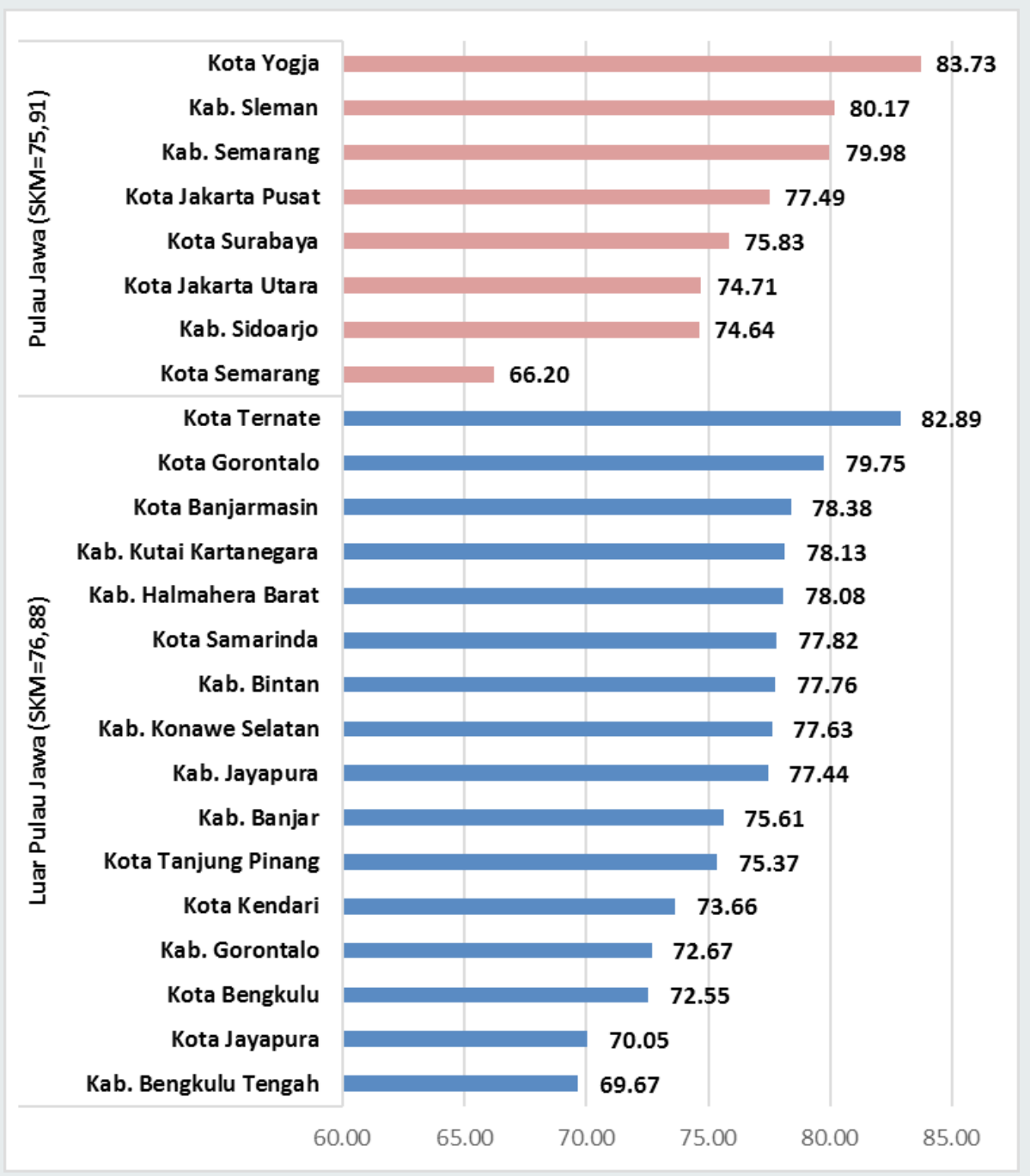

Gambar 4.29. Nilai SKM Menurut Wilayah Pulau Jawa dan Luar Pulau Jawa 


\subsection{Penilaian Masyarakat Terhadap Pelayanan Kantor Pertanahan (Indepth Interview)}

Penilaian masyarakat yang telah memanfaatkan layanan Kantor Pertanahan melalui kegiatan indepth interview dengan mengambil $10 \%$ dari jumlah sampel pada setiap Kantor Pertanahan telah menghasilkan informasi tambahan yang meliputi beberapa tema pokok pertanyaan, antara lain Persyaratan Pelayanan, Prosedur Pelayanan, Waktu Pelayanan, Biaya atau Tarif, Kejelasan Petugas/Pelaksana, Kompetensi Pelaksana, Perilaku Pelaksana, Maklumat Pelayanan dan Keamanan/Kenyamanan pada lokasi penyedia pelayanan.

\subsubsection{Persyaratan dan Prosedur Pelayanan}

Dalam proses pemanfaatan layanan pada setiap jenis pelayanan di Kantor Pertanahan dibutuhkan kelengkapan berkas yang menjadi persyaratan dan harus mengikuti prosedur yang sudah dibakukan. Dari hasil penilaian masyarakat terhadap Persyaratan Pelayanan pada lokasi sampel berdasarkan keselurahan jenis pelayanan yang sudah diakses masyarakat bisa diketahui keterbukaan, kejelasan dan kemudahan pemenuhan persyaratannya. Pada sisi keterbukaan dan kejelasan persyaratan, sebagian besar masyarakat menilai sudah ada keterbukaan dan kejelasan yang cukup. Dari 24 Kantor Pertanahan sampel, masyarakat yang menilai Persyaratan Pelayanan pada Kantor Pertanahan sudah terbuka dan jelas sebanyak 90,86 \% sedangkan sisanya menganggap masih tidak terbuka/jelas. Pada aspek kemudahan untuk memenuhi persyaratan, masyarakat yang menganggap mudah untuk memenuhi persyaratan pelayanan adalah sebesar 90,29. Penilaian masyarakat didasari oleh kemudahan memperoleh informasi, baik datang langsung ke Kantor Pertanahan kemudian bertanya langsung kepada petugas atau melihat papan informasi yang ada di bagian loket. Selain itu informasi persyaratan pelayanan dapat diketahui dengan mengakses website Kementerian Agraria dan Tata Ruang/ Badan Pertanahan Nasional ataupun website Kantor Pertanahan setempat. Begitu juga dengan aspek kemudahan pemenuhan persyaratannya. Anggapan kemudahan pemenuhan persyaratan didasari oleh kenyataan bahwa item berkasnya cukup banyak dan untuk dapat memperolehnya tidak hanya dari Kantor Pertanahan sendiri, melainkan harus dari berbagai tempat seperti Kantor Desa/Kecamatan, Kantor Pajak/Dinas Pendapatan Daerah, Pejabat Pembuat Akta Tanah dan beberapa instansi lain yang terkait. Sistem birokrasi yang belum satu atap inilah yang cenderung membuat masyarakat sebagai pemohon menganggap sulit untuk memenuhi persyaratan untuk mendapatkan pelayanan dari Kantor Pertanahan.

Masyarakat menilai tentang prosedur pelayanan seperti dari sisi keterbukaan informasi, kejelasan alur dan kesederhanaan sudah cukup baik dengan rata-rata diatas $80 \%$. Masyarakat juga menilai bahwa petugas sudah memberikan pelayanan sesuai prosedur $(86,6 \%)$, petugas tidak menawarkan percepatan $(85,71 \%)$ dan petugas tidak menerima tawaran di luar prosedur $(85,14 \%)$. Persentase terendah dari diberikan untuk penilaian bahwa tidak ada peluang timbul KKN $(75,29 \%)$ dan tidak terdapat praktek percaloan ( 76,02 \%). 


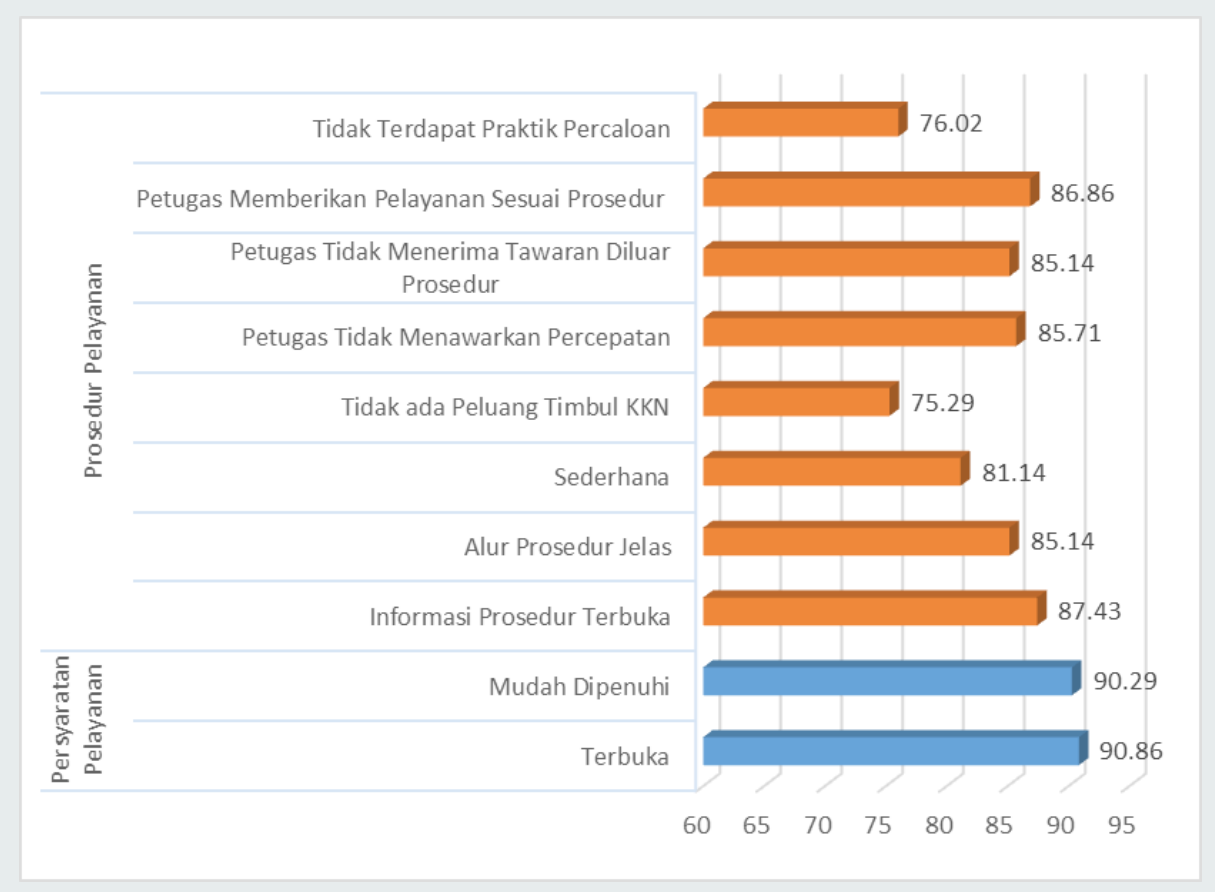

Gambar 4.30. Persentase Hasil Indept Interview Penilaian Masyarakat Terhadap Aspek Persyaratan dan Prosedur Pelayanan

\subsubsection{Penilaian Masyarakat Terhadap Aspek Waktu Pelayanan dan Biaya/Tarif}

Hasil skoring indepth interview IKM dari 24 Kabupaten/Kota pada 14 provinsi sampel untuk aspek waktu dan biaya/tarif layanan menunjukan bahwa waktu layanan masih menjadi hal yang perlu dibenahi. Hal ini dikarenakan dari empat sub aspek yang ditanyakan pada aspek waktu layanan hanya pada kejelasan waktu layanan saja yang memiliki skor dengan persentase cukup tinggi yaitu $78,98 \%$. Sementara pada sub aspek lainya relatif rendah yaitu $66,48 \%$ untuk informasi target penyelesaian dan 64,77 untuk pelaksanaan waktu pelayanan. Bahkan untuk pelaksanaan penyelesaian dinilai lebih rendah lagi oleh responden dengan hanya memperoleh skor 56,32. Pola yang terlihat disini adalah waktu layanan pertanahan dinilai oleh masarakat cukup bagus pada sisi informasi sedangkan untuk pelaksanaan masih belum sesuai harapan terutama untuk penyelesaianya.

Sedangkan untuk aspek biaya/tarif layanan penilaian yang diberikan masyarakat sudah baik. Hal ini ditunjukan dengan perolehan skor/persentase aspek ini yang berkisar antara $82 \%$ sampai dengan 94\%. Dari sisi biaya masyarakat memberikan nilai yang sangat baik yaitu diatas $90 \%$ untuk semua sub aspek yang terdiri dari kejelasan biaya, kesesuaian dengan peraturan, terjangkau dan tingkat kewajaran. Sementara dari sisi keterkaitan biaya layanan dengan petugas layanan, dari lima pertanyaan yang diajukan memperoleh skor mulai dari kisaran $79 \%$ sampai $85 \%$. Hal ini sekaligus menunjukan integritas dari petugas dengan tidak menerima atau meminta biaya di luar tarif yang telah ditetapkan. 
Jadi bisa disimpulkan masyarakat sudah memberikan apresiasi yang baik untuk aspek biaya/ tarif baik pada sisi nominal maupun personal petugas yang memberikan layanan. Sedangkan untuk aspek waktu, masyarakat mengharapkan adanya peningkatan pada pelaksanaan dan penyelesaian pekerjaan sesuai dengan informasi yang diberikan. Adapun hasil penilaian untuk setiap lokasi sampel dapat dilihat secara lebih detil pada gambar 4.31.

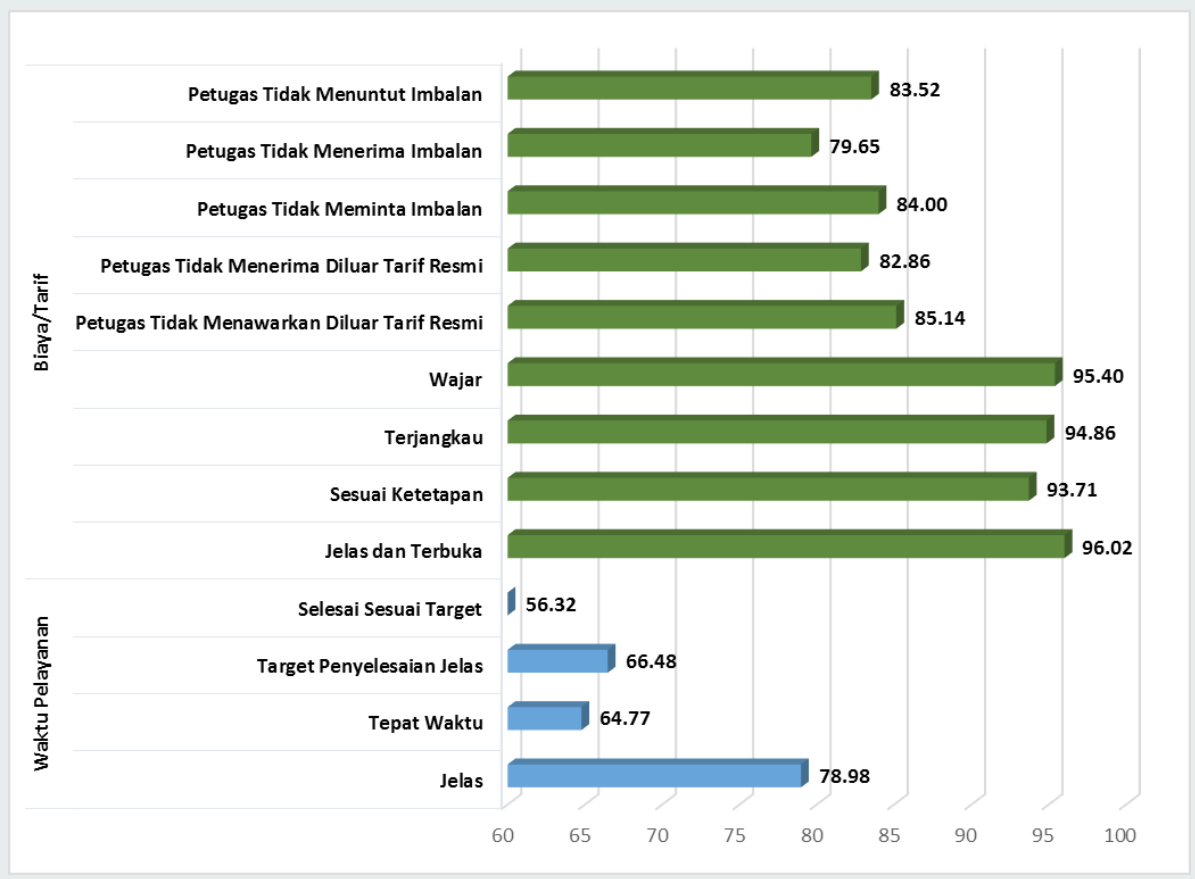

\section{Gambar 4.31. Persentase Hasil Indept Interview Penilaian Masyarakat Terhadap Aspek Waktu Pelayanan dan Biaya/Tarif Layanan.}

\subsubsection{Penilaian Masyarakat Terhadap Aspek Penanganan Pengaduan, Saran dan Masukan.}

Dari hasil pengolahan data indepth interview pada aspek layanan pengaduan, saran dan masukan diperoleh skor tertinggi pada sub aspek ketersediaan sarana pengaduan dengan $88,82 \%$. Hal ini menunjukan mayoritas Kantor Pertanahan sudah menyediakan sarana untuk mengakomodasi saran, masukan ataupun pengaduan dari masyarakat. Hanya saja media penampung yang sudah ada dan dinilai baik oleh masyrakat ini kurang dibarengi dengan kegiatan lanjutan dengan sama baiknya. Hal ini tercermin dari nilai yang diberikan mulai dari kejelasan pengelolaan, prosedur dan terakhir kepastian tindak lanjut yang semakin menurun mulai dari $80 \%$ sampai pada kisaran $78 \%$.

Untuk aspek pelaksana, secara kualitas oleh masyarakat sudah dinilai baik sebagaimana terlihat dari skor yang diberikan berada pada kisaran angka $90 \%$. Kemampuan teknis petugas mendapat penilaian terbaik dengan 92,57\% diikuti kemampuan administrasi dengan $90,86 \%$ dan terakhir kesigapan petugas $89,20 \%$. Sementara dari segi kuantitas meskipun dari segi kehadiran dan keberadaan petugas untuk melayani konsumen diapresiasi dengan sangat tinggi oleh masyarakat dengan skor $94,29 \%$, jumlah petugas yang ada masih dianggap kurang

\section{Pusat Penelitian dan Pengembangan}


seimbang. Hal ini ditunjukan dengan nilai sebesar 73,86 , yang artinya petugas yang sudah ada dirasa masih kurang untuk melayani konsumen yang datang. Persepsi masyarakat ini dimungkinkan timbul karena antrian tunggu yang dirasa cukup lama. Gambar 4.32 menyajikan informasi tersebut dalam bentuk grafis.

Pada kelompok aspek ini disimpulkan bahwa masyarakat mengapresiasi tinggi kualitas petugas ditambah lagi dengan komitmennya yang tinggi untuk selalu stand-by dalam melayani konsumen. Selanjutnya terdapat area yang perlu diperbaiki yaitu pada penindaklanjutan input yang diberikan oleh masyarakat baik positif maupun negatif. Kemudian satu hal yang perlu ditambahkan adalah jumlah petugas pelayanan supaya lebih mengurangi antrian. Detail penilaian aspek-aspek tersebut pada seluruh Kantor Pertanahan lokasi disajikan pada (gambar 4.32).

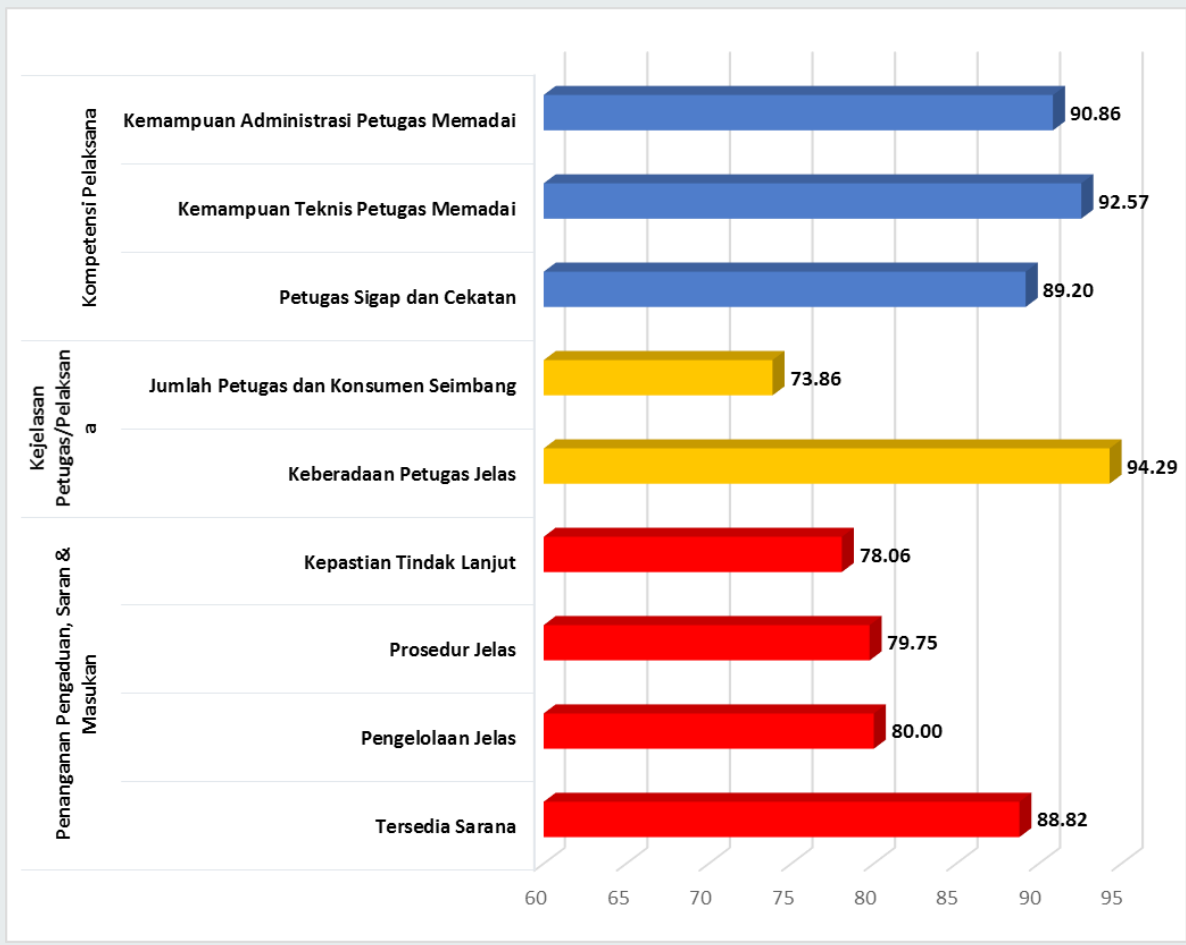

Gambar 4.32. Persentase Hasil Indept Interview Penilaian Masyarakat Terhadap Aspek Penanganan Pengaduan, Saran dan Masukan, Kejelasan Petugas/Pelaksana dan Kompetensi Pelaksana

\subsubsection{Penilaian masyarakat terhadap aspek perilaku pelaksana dan maklumat pelayanan}

Perilaku pelaksana sangat penting dan sangat berperan dalam penilaian masyarakat terhadap kinerja layanan kantor karena merupakan orang yang behubungan langsung dengan masyarakat pemohon. Sedangkan maklumat merupakan janji yang harus dijalankan dan dipedomani

oleh petugas pelaksana dalam memberikan layanan pertahanan. Dari hasil pengolahan data indepth interview aspek perilaku pelaksana secara umum sudah memperoleh nilai yang baik 
bahkan untuk sub aspek sikap dan perilaku petugas dinilai sangat baik dengan memperoleh skor $96,59 \%$ (gambar 4.33). Sub aspek lainya seperti tanggung jawab petugas dan kesamaan perlakuan terhadap konsumen juga memperoleh penilaian baik pada kisaran $90 \%$. Sedangkan sub aspek yang dinilai sedikit lebih rendah adalah disiplin dalam menyelesaikan pelayanan dengan nilai $84 \%$. Penilaian ini dimungkinkan karena dipengaruhi oleh waktu pelayanan yang memang kerap kali dikeluhkan kurang tepat, sehingga ada anggapan petugas kurang disiplin dalam melaksanakan tugasnya.

Sementara untuk maklumat pelayanan, masyarakat menilai sebesar $77,65 \%$ untuk kejelasan maklumat dan $71,76 \%$ untuk tindakan pelayanan sesuai maklumat. Maklumat pelayanan itu sendiri merupakan pernyataan kesanggupan dan kewajiban penyelenggara untuk melaksanakan pelayanan sesuai standar. Maklumat biasanya dipasang di ruang loket supaya bisa dilihat dan dibaca oleh pengguna layanan. Penilaian sebesar $77,65 \%$ untuk kejelasan maklumat menunjukan bahwa sebagian kecil masyarakat masih belum mengetahui atau menyadari perihal kewajiban yang harus dipenuhi petugas untuk memberikan pelayanan yang terbaik. Berdasarkan pengamatan lapang memang masih terdapat Kantor Pertanahan yang tidak memasang maklumat. Selanjutnya untuk tindakan pelayanan dinilai lebih rendah yaitu sebesar $71,76 \%$ yang artinya bagi masyarakat yang mengetahui adanya maklumat pelayanan menilai pelayanan yang diberikan belum maksimal dan memenuhi maklumat.

Dari dua aspek penilaian kepuasan diatas disimpulkan bahwa petugas sudah memiliki sikap dan tanggung yang baik dalam memberikan pelayanan yang sama kepada semua tingkat dan kelompok masarakat. Aspek disiplin yang dianggap masih kurang bisa saja ditingkatkan dengan pelayanan yang lebih tepat waktu. Disamping itu maklumat pelayanan serta pelaksanaannya di Kantor Pertanahan masih terindikasi kurang maksimal. Penilaian aspek maklumat dan perilaku pelaksana pada kantor petanahan lokasi bisa dilihat pada gambar 4.33.

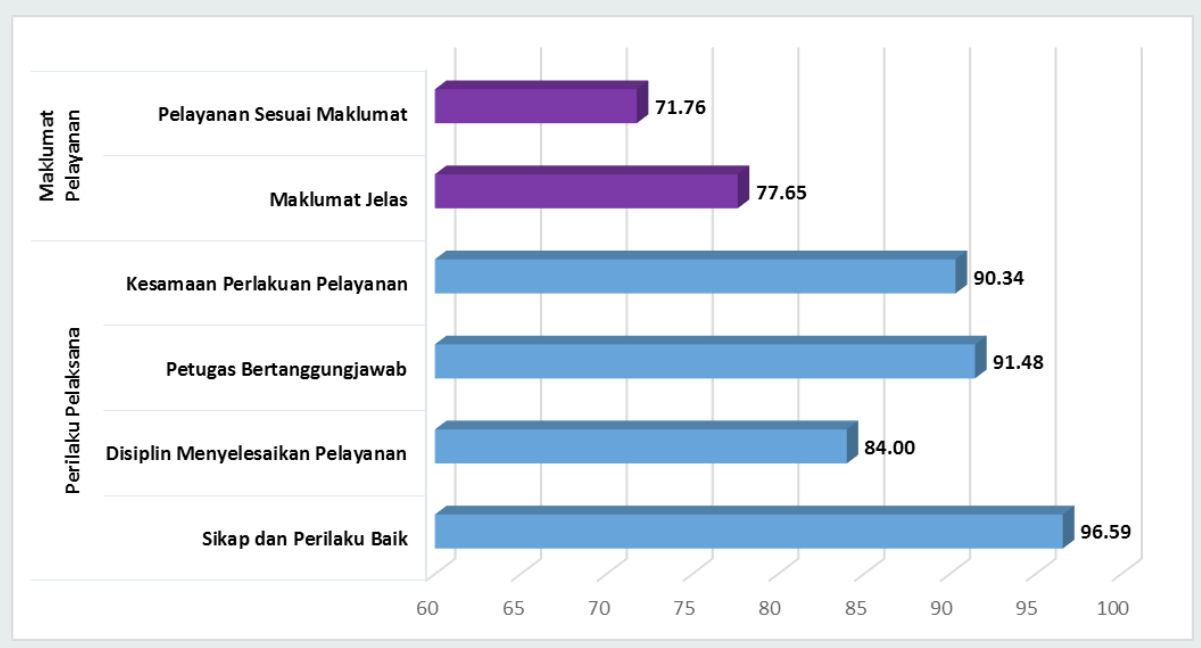

Gambar 4.33. Persentase Hasil Indept Interview Penilaian Masyarakat Terhadap Aspek Perilaku Pelaksana dan Maklumat Pelayanan 
4.3.5 Penilaian Masyarakat Terhadap Aspek Keamanan, Kenyamanan dan Komitmen Penyelenggara Pelayanan Publik

Lingkungan tempat pelayanan termasuk di dalamnya sarana dan prasarana merupakan aspek yang penting untuk menunjang tingkat kepuasan konsumen terutama pada bagian loket yang merupakan wajah dari Kantor Pertanahan. Penilaian masyarakat dalam hal keamanan lingkungan mencapai nilai maksimal yaitu 100\%. Dalam hal kelengkapan dan kelayakan serta kebersihan dan kenyamanan sarana prasarana juga diberi nilai yang baik oleh masyarakat pengguna layanan dengan berada pada kisaran nilai $82 \%$ dan $89 \%$. Nilai rendah diberikan untuk sarana untuk para difabel yaitu sebesar $61,64 \%$. Hal ini juga sesuai dengan pengamatan langsung di lapang pada kantor-kantor pertanahan lokasi yang memang kurang ramah untuk para difabel. Sub aspek lainya yang termasuk dalam aspek keamanan dan kenyamanan adalah kemudahan untuk berkomunikasi dengan petugas. Untuk hal ini masyarakat memberikan nilai baik yaitu $87,86 \%$. Tingginya penilaian sub aspek ini kemungkinan dipengaruhi oleh adanya teknologi yang sudah merata sehingga bisa diakses semua lapisan yang memungkinkan komunikasi yang lancar tanpa harus bertatap muka langsung.

Aspek lain yang terkait dengan kenyamanan layanan adalah lingkungan kerja yang jauh dari unsur korupsi sehingga mendukung pelayanan berjalan dengan baik. Untuk hal ini masyarakat menilai lembaga ATR/BPN telah menuju instansi yang bebas korupsi dengan memberikan apresiasi sebesar 90,06\%. Artinya masyarakat sudah melihat adanya perubahan dalam tubuh lembaga ini dari yang dulunya sangat kental dengan budaya KKN menjadi lembaga yang bersih. Pelayanan yang ada terutama di Kantor Pertanahan juga dinilai sudah berjalan dengan baik terlihat dari nilai $87,21 \%$ yang diberikan oleh masyarakat.

Secara ringkas bisa dikatakan bahwa masyarakat sudah puas dengan lingkungan kerja dan fasilitas pelayanan pada Kantor Pertanahan lokasi. Fasilitas kantor yang perlu pembenahan dan atau penambahan ke depan berupa penyediaan sarana dan prasarana untuk para penyandang difabilitas. Secara lengkap penilaian aspek ini ada di bagian gambar 4.34.

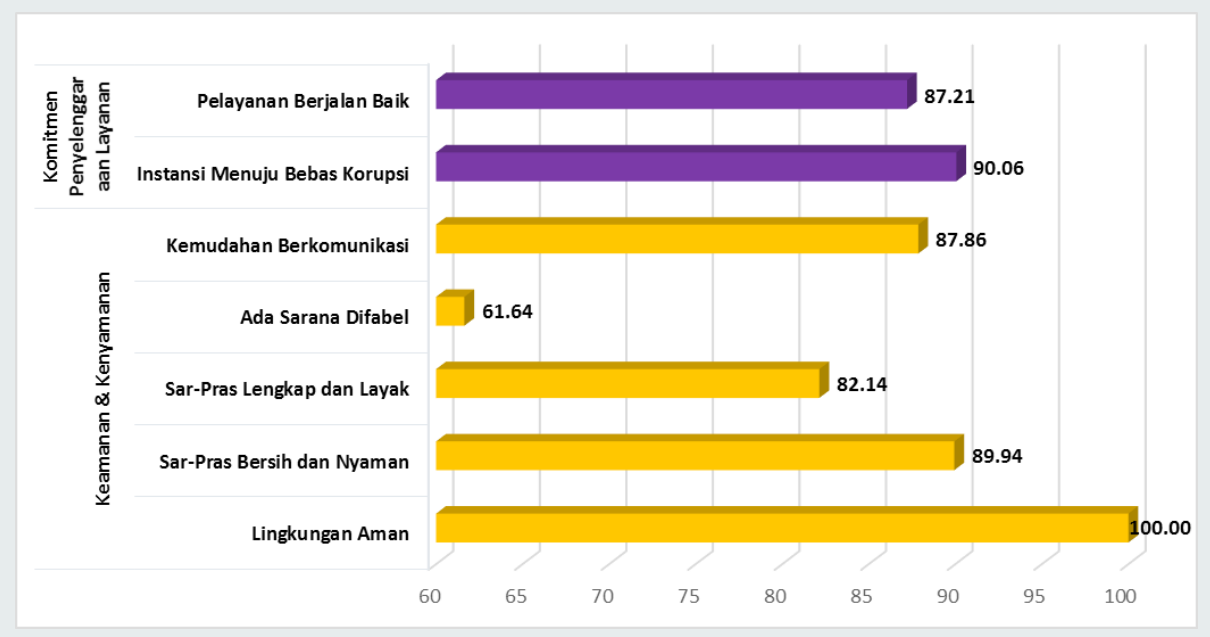

Gambar 4.34. Persentase Hasil Indepth Interview Penilaian Masyarakat Terhadap Aspek Keamanan, Kenyamanan dan Komitmen Penyelenggara Pelayanan Publik 


\subsection{Observasi Kantor Pertanahan}

Penilaian kondisi Kantor Pertanahan dilaksanakan melalui kuesioner sederhana dimana responden menjawab Ya atau Tidak sesuai dengan pengalamannya saat mengakses layanan pertanahan. Selain itu, penjelasan mengenai kondisi Kantor Pertanahan diperkuat secara kualitatif dimana responden dapat menuangkan pengalaman tersebut dalam bentuk tekstual sehingga menjelaskan jawaban sebelumnya. Dari hasil indepth interview dapat diketahui bahwa responden memiliki pengalaman yang sangat variatif, ada yang sesuai dengan harapan dan ada juga yang belum memenuhi harapan responden akan kondisi layanan pertanahan. Hasil observasi Kantor Pertanahan tersebut tertuang dalam grafik pada Gambar 4.35.

Ketentuan mengenai kondisi Kantor Pertanahan terdapat pada Peraturan Kepala BPN RI Nomor 3 Tahun 2010 tentang Loket Pelayanan Pertanahan. Pada Gambar 4.35 memperlihatkan kondisi Kantor Pertanahan dari yang lengkap sesuai ketentuan hingga belum terlalu lengkap. Lengkap disini bukan berarti kantor yang bagus dan mewah, tetapi memenuhi standar yang sudah ditentukan antara lain seperti adanya panel informasi baik mengenai persyaratan, biaya maupun waktu. Beberapa kantor pertanahan belum memasang panel bagan alir, sarana untuk disabilitas, ruang menyusui dan ruang bermain anak serta toilet yang terpisah pria dan wanita. Kantor yang dalam kondisi hampir sesuai dengan ketentuan adalah Kantor Pertanahan Kota Ternate, Jakarta Pusat, Kota Semarang dan Kabupaten Semarang.

\section{NILAI OBSERVASI KANTOR PER KABUPATEN/KOTA}

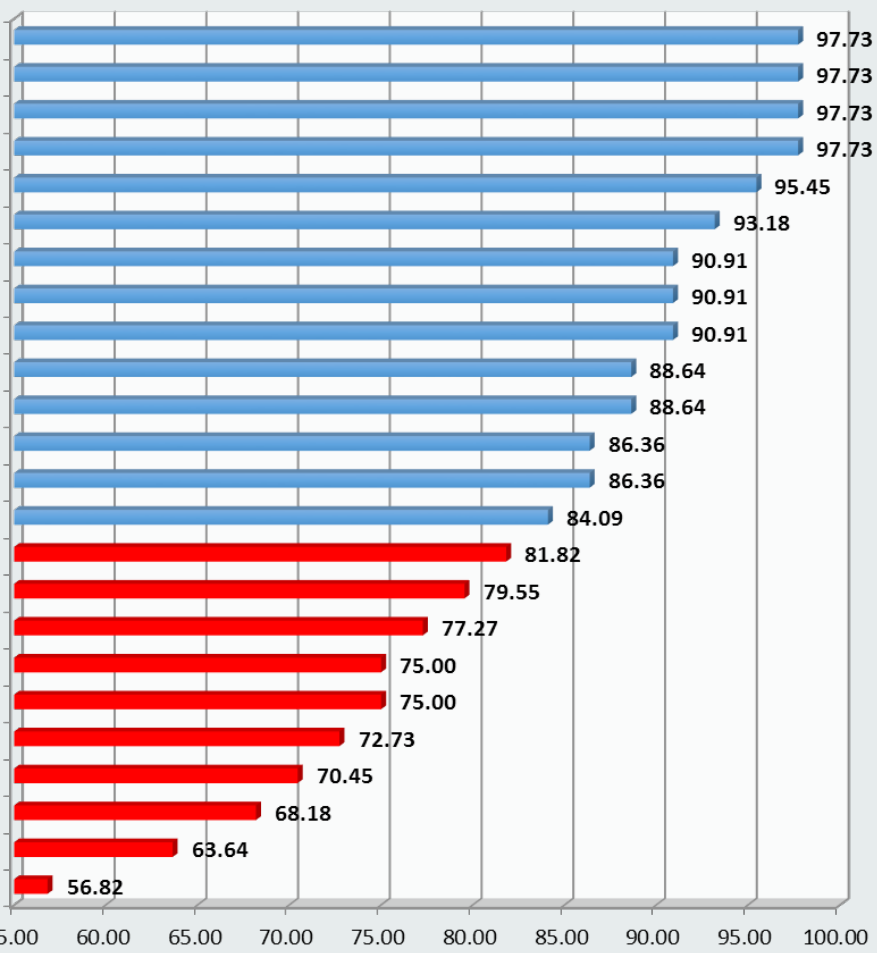

Gambar 4.35. Grafik Nilai Observasi Kantor Pertanahan Per Kabupaten/Kota

\section{Pusat Penelitian dan Pengembangan}




\subsubsection{Kondisi Loket Pelayanan}

Loket pelayanan berfungsi memberikan pelayanan informasi, pelayanan administrasi, pelayanan pengaduan dan pelayanan keuangan. Kualitas Loket pelayanan merupakan salah satu tolok ukur kinerja BPN dalam melayani masyarakat. Peningkatan kualitas loket pelayanan merupakan bagian dari upaya membangun kepercayaan masyarakat. Kondisi loket menjelaskan mengenai keberadaan meja loket, ruang tunggu, meja isi blanko, bagan alir, persyaratan, biaya/tarif, jangka waktu, dan nomor antrian.

Pada Gambar 4.36 memperlihatkan meja loket sudah baik mendapat nilai 100 persen. Kemudian mayoritas sudah menggunakan nomor antrian baik digital maupun manual, dan tersedia bagan persyaratan (83,33\%), demikian pula untuk ruang tunggu cukup memadai $(79,17 \%)$. Fasilitas yang jarang terdapat di Kantor Pertanahan adalah keberadaan bagan alir ( $50 \%)$, panel informasi biaya $(70,83 \%)$ dan informasi jangka waktu. Demikian juga ketersediaan meja isi blanko/formulir cukup rendah (58,33\%).

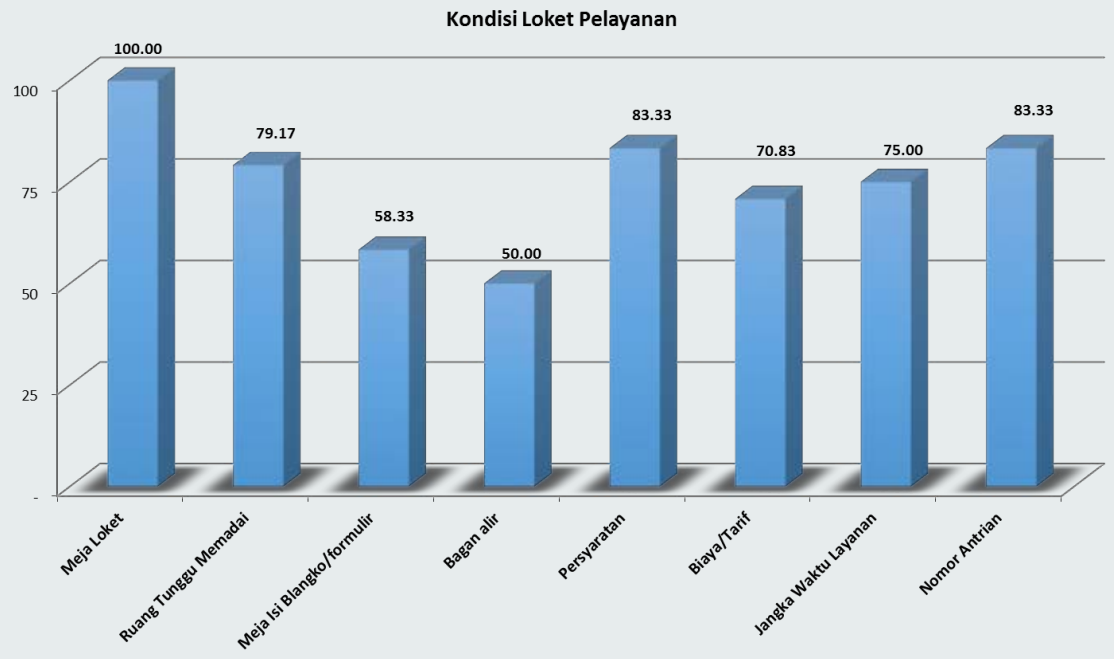

Gambar 4.36. Kondisi Loket Pelayanan 


\subsubsection{Kualitas Petugas Loket Layanan}

Menurut grafik hasil observasi kantor, menunjukkan nilai terendah terdapat pada ketepatan waktu, minimal masa kerja, dan pengalaman kerja. Untuk ketepatan waktu yang kurang baik, pada beberapa kantor biasanya terjadi pada saat setelah jam istirahat, dimana ada beberapa petugas yang terlambat kembali ke loket. Sedangkan untuk pagi hari, rata-rata sudah sesuai waktu jam buka loket. Sedangkan untuk penilaian minimal masa kerja dan pengalaman kerja petugas loket saling terkait, dimana jika masa kerjanya masih kurang, maka pengalaman kerjanya juga akan kurang. Hal ini bisa terjadi karena penunjukkan petugas loket yang kurang tepat. Pada beberapa kantor, petugas loket yang ditunjuk merupakan pegawai tidak tetap yang belum lama bekerja sehingga masih minim pengalaman kerjanya. Di samping itu ada juga penunjukan petugas loket yang hanya berdasarkan penampilan yang menarik, tetapi agak kurang dipertimbangkan kualitas dan pengalaman kerjanya. Walaupun petugas loket yang ditunjuk masih kurang dalam hal minimal masa kerja dan pengalaman kerja, tetapi sudah cukup informatif, cekatan, dan tidak mempersulit. Untuk petugas loket yang ditunjuk, sebelum ditugaskan di loket, harus dibekali dengan pengetahuan yang cukup melaui pendidikan/ pelatihan. Untuk hal-hal yang sifatnya non teknis, seperti kesopanan, keramahan, kerapian, tanggung jawab, dan seragam semua mendapatkan nilai maksimal.

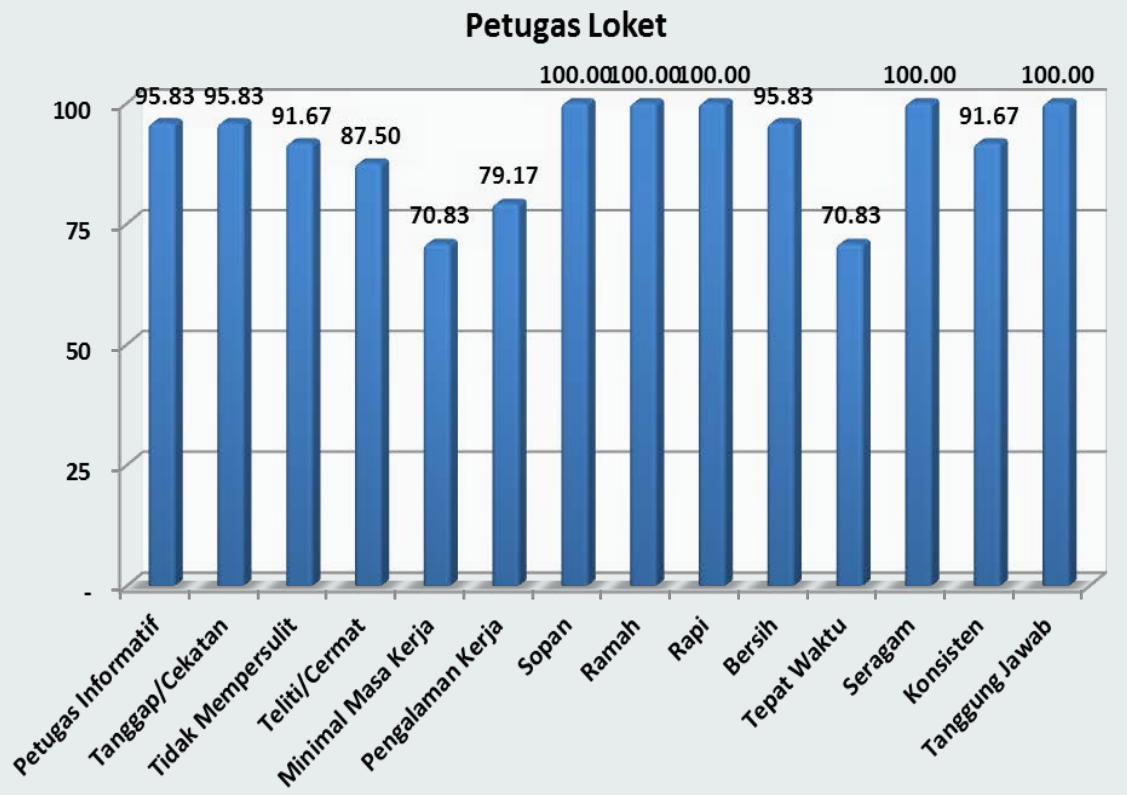

Gambar 4.37. Kualitas petugas loket pelayanan

Pada Gambar 4.37 memperlihatkan kualitas petugas loket memiliki nilai sempurna di seluruh Kantor Pertanahan sampel, terutama dari aspek kesopanan, ramah, rapi, berpakaian seragam dan bertanggung jawab.

Bagi loket Kantor Pertanahan tertentu yang memiliki jumlah SDM pegawai dalam jumlah terbatas maka sebagian dilengkapi dengan Pegawai Tidak Tetap. Pegawai Tidak Tetap diperoleh dari proses seleksi sehingga aspek kedisiplinan dan penampilan menjadi faktor penunjang 
guna memberikan pelayanan prima. Permasalahan lain yang kemudian muncul adalah masa kerja dan pengalaman petugas loket yang dimiliki pada sebagian Kantor Pertanahan belum mencukupi. Hal ini bisa ditemukan dan menurut pihak kantor sangat mungkin terjadi karena proses rotasi juga berlaku pada bagian loket ini. Di samping itu bagi kantor yang terbatas SDM mau tidak mau menempatkan petugas seadanya dengan diberikan bekal pengetahuan pertanahan dalam waktu singkat.

\subsubsection{Sarana dan Prasarana Layanan Pertanahan}

Untuk sarana dan prasarana loket, secara umum sudah sesuai ketentuan, seperti posisi loket yang di depan sehingga mudah dikenali dan standar minimal loket juga sudah terpenuhi. Peralatan pendukung pelayanan juga sudah cukup baik keberadaannya, seperti peralatan $\mathrm{TI}$ dan penyimpanan arsip. Sarana dan prasarana yang masih kurang antara lain: P3K, perlengkapan keamanan, dan media pengaduan.

Setengah dari Kantor Pertanahan lokasi sampel belum menyediakan sarana untuk P3K. Selama ini, di Kantor Pertanahan jarang sekali terjadi masalah yang berhubungan dengan kesehatan/ kecelakaan, baik dari pemohon maupun petugas. Hal inilah yang menyebabkan sebagian Kantor Pertanahan mengabaikan keberadaan sarana P3K tersebut. Untuk perlengkapan keamanan sebenarnya sudah cukup baik, tetapi ada beberapa Kantor Pertanahan yang belum menyediakan. Keberadaan petugas keamanan (satpam) mungkin sudah dirasa cukup, sehingga merasa tidak perlu menambah dengan sarana perlengkapan keamanan. Kekurangan dari sarana media pengaduan adalah dalam bentuk kotak pengaduan. Adanya media pengaduan online membuat beberapa kantor mengabaikan keberadaan kotak pengaduan di ruang tunggu loket, yang seharusnya tetap disediakan untuk pemohon. Di samping itu, pada beberapa kantor masih membiarkan pemohon bertemu langsung petugas (back office), sehingga pemohon bisa langsung melaksanakan pengaduan langsung ke petugas yang bersangkutan.

\section{Sarana dan Prasarana}

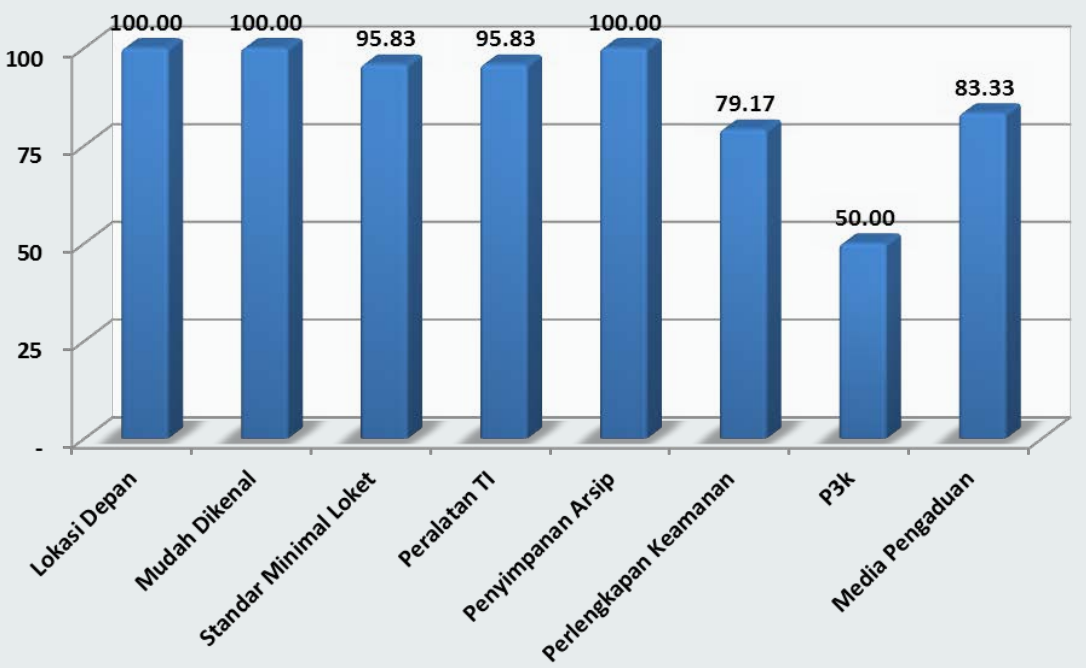

Gambar 4.38. Sarana dan Prasarana Layanan Pertanahan 
Dari gambar di atas menunjukkan nilai sempurna diperoleh untuk penilaian lokasi depan, mudah dikenal dan penyimpanan arsip (100\%). Penyempurnaan yang paling banyak untuk diperbaiki adalah ketersediaan perlengkapan P3K mengingat sebagian lokasi sampel menunjukkan kekurangan pada item tersebut, yakni hanya terdapat di $50 \%$ Kantor Pertanahan saja. Walaupun tidak sering digunakan, akan tetapi perlengkapan P3K adalah hal yang harus disediakan agar meningkatkan kenyamanan bagi masyarakat pengguna layanan.

\subsubsection{Peningkatan Prosedur Pelayanan}

Kondisi peningkatan prosedur pelayanan pada umumnya sudah cukup baik. Nilai tertinggi peningkatan prosedur pelayanan adalah kemampuan petugas menerangkan, adanya kamera CCTV, dan kesiapan fasilitas pelayanan. Sesuai dengan uraian tentang kualitas petugas loket pelayanan, bahwa rata-rata petugas loket sudah cukup informatif atau mempunyai kemampuan yang cukup baik untuk menerangkan pertanyaan-pertanyaan dari pemohon terkait pelayanan di Kantor Pertanahan. Untuk kamera CCTV, pada jaman teknologi seperti sekarang sangat mudah dan murah untuk mendapatkan, sehingga hampir semua kantor sudah memilikinya. Kesiapan fasilitas pelayanan juga sudah cukup baik. Dengan terselenggaranya pelayanan di kantor-kantor pertanahan, menunjukkan bahwa fasilitas-fasilitas pelayanan yang ada sudah dipersiapkan dengan baik.

Sedangkan untuk penilaian terendah pada peningkatan prosedur pelayanan adalah keberadaan brosur/leaflet dan inovasi/terobosan. Keberadaan brosur/leaflet pada loket palayanan jarang ditemui dikarenakan pada kantor-kantor yang sudah memasang bagan alir pelayanan, persyaratan, jangka waktu, maupun pembiayaan dalam ukuran yang relatif besar, merasa tidak perlu lagi menyediakan brosur/leaflet yang ukurannya lebih kecil. Pada beberapa Kantor Pertanahan justru ada yang sudah berbentuk digital yang ditampilkan pada layar monitor. Dan untuk inovasi/terobosan pada saat sekarang jarang dijumpai di kantor-kantor pertanahan, tetapi masih ada yang menerapkan inovasi seperti weekend service, dan lain-lain. Sejak tahun 2017, yaitu sejak dicanangkannya program Pendaftaran Tanah Sistematis Lengkap (PTSL) dengan target yang relatif tinggi, kebanyakan Kantor Pertanahan kewalahan jika harus menerapkan inovasi/terobosan. 


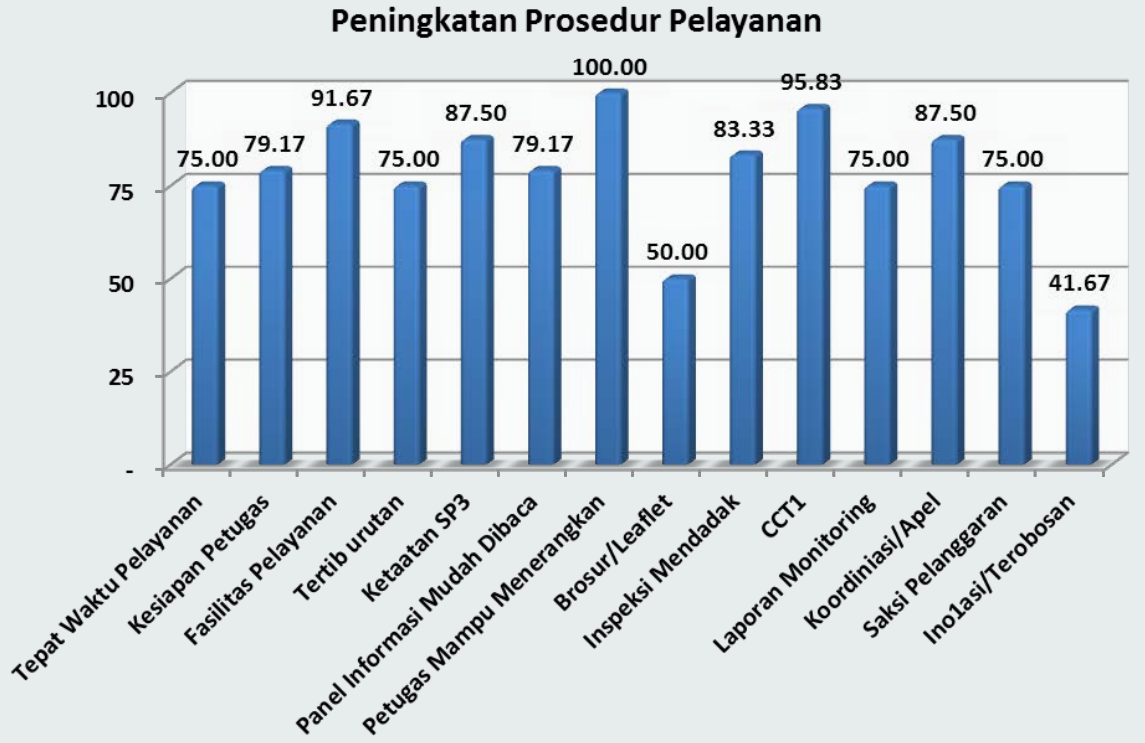

Gambar 4.39. Peningkatan Prosedur Pelayanan

\subsection{Analisis hubungan terhadap unsur pelayanan}

Dalam rangka menjelaskan hubungan yang kompleks antara satu unsur dengan unsur lain diperlukan analisis bivariat. Tujuan dari analisis bivariat ini adalah untuk melihat hubungan satu unsur dengan unsur lain sebagai dasar untuk menjelaskan suatu masalah. Melalui analisis ini, hasil pengolahan data SKM tidak hanya dimunculkan analisis kuantitatif saja (indeks atau angka SKM), tetapi juga analisis kualitatif. Analisis ini sangat penting untuk perbaikan kualitas pelayan publik maupun pengambilan kebijakan dalam rangka pelayanan publik. Oleh karena itu, hasil analisis ini perlu dibuatkan dan direncanakan tindak lanjut perbaikan. Rencana tindak lanjut perbaikan dapat dilakukan dengan prioritas dimulai dari unsur yang paling buruk hasilnya. Penentuan perbaikan harus direncanakan tindak lanjut dengan prioritas perbaikan jangka pendek (kurang dari 12 bulan), jangka menengah (lebih dari 12 bulan, kurang dari 24 bulan), atau jangka panjang (lebih dari 24 bulan).

Salah satu analisis bivariat yang dapat digunakan untuk mengetahui hubungan antar variabel adalah analisis korelasi. Analisis korelasi adalah suatu cara atau metode untuk mengetahui ada atau tidaknya hubungan linear antar variabel. Apabila terdapat hubungan maka perubahanperubahan yang terjadi pada salah satu variabel $X$ akan mengakibatkan terjadinya perubahan pada variabel lain (Y). 


\begin{tabular}{|c|c|c|c|c|c|c|c|c|c|}
\hline 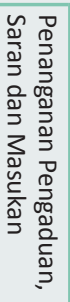 & 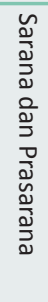 & 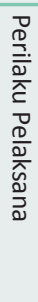 & 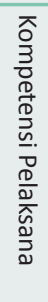 & 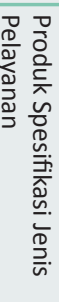 & 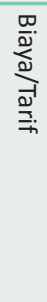 & 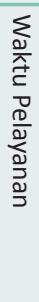 & 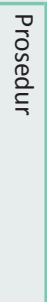 & 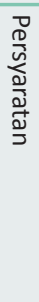 & \\
\hline 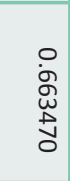 & $\begin{array}{l}0 \\
\infty \\
\infty \\
0 \\
\text { N } \\
\text { N }\end{array}$ & 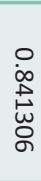 & $\begin{array}{l}0 \\
0 \\
0 \\
0 \\
0 \\
\text { ஸे }\end{array}$ & $\begin{array}{l}\circ \\
\dot{8} \\
\varnothing \\
+ \\
\infty\end{array}$ & $\begin{array}{l}0 \\
\stackrel{+}{0} \\
\stackrel{0}{0} \\
\infty \\
\infty\end{array}$ & $\begin{array}{l}0 \\
\infty \\
\infty \\
\infty \\
\infty \\
N \\
N\end{array}$ & $\begin{array}{l}0 \\
0 \\
0 \\
0 \\
0 \\
0 \\
0\end{array}$ & $\begin{array}{l}\dot{\circ} \\
\dot{8} \\
\dot{8}\end{array}$ & 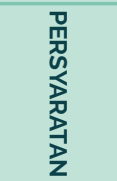 \\
\hline 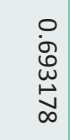 & $\begin{array}{l}0 \\
\text { gे } \\
0 \\
0 \\
0 \\
0\end{array}$ & 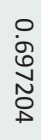 & 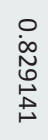 & 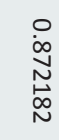 & 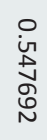 & $\begin{array}{l}0 \\
\infty \\
\stackrel{1}{N} \\
\delta \\
0\end{array}$ & $\begin{array}{l}\text { ! } \\
\dot{8} \\
8\end{array}$ & $\begin{array}{l}0 \\
\text { o } \\
0 \\
W \\
0 \\
0 \\
\omega\end{array}$ & 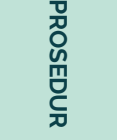 \\
\hline $\begin{array}{l}0 \\
\text { in } \\
\infty \\
\text { N } \\
\infty\end{array}$ & $\begin{array}{l}0 \\
\dot{D} \\
\stackrel{\infty}{\infty} \\
\stackrel{D}{\perp}\end{array}$ & 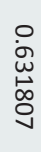 & $\begin{array}{l}0 \\
\infty \\
\infty \\
\infty \\
\stackrel{N}{N}\end{array}$ & 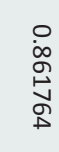 & $\begin{array}{l}0 \\
\text { in } \\
\text { o } \\
\text { †े }\end{array}$ & $\begin{array}{l}\text { ம் } \\
\text { ठ } \\
\dot{8}\end{array}$ & 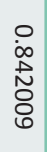 & $\begin{array}{l}0 \\
\infty \\
\infty \\
\infty \\
\infty \\
N \\
N\end{array}$ & 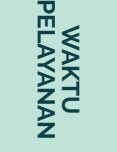 \\
\hline $\begin{array}{l}\stackrel{0}{\tilde{N}} \\
\text { ज̃ } \\
\text { D }\end{array}$ & $\begin{array}{l}0 \\
\dot{B} \\
\text { Ũ } \\
\text { O }\end{array}$ & 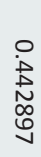 & 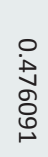 & 㭊 & $\begin{array}{l}+ \\
\dot{8} \\
\dot{8}\end{array}$ & $\begin{array}{l}0 \\
\text { in } \\
\text { مे } \\
\text { †े } \\
0\end{array}$ & $\begin{array}{l}0 \\
\text { in } \\
\pm \\
\text { o } \\
\text { N }\end{array}$ & $\begin{array}{l}0 \\
\dot{b} \\
\stackrel{\bullet}{0} \\
\stackrel{\infty}{\infty} \\
\infty\end{array}$ & 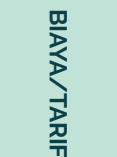 \\
\hline $\begin{array}{l}0 \\
\text { Ñ } \\
\infty \\
0 \\
0 \\
0\end{array}$ & 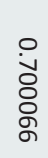 & 음 & $\begin{array}{l}0 \\
\dot{\infty} \\
\text { N } \\
\tilde{N} \\
\text { o }\end{array}$ & மே & 음 & 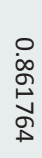 & 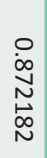 & $\begin{array}{l}0 \\
\dot{b} \\
\varnothing \\
\stackrel{+}{+} \\
\infty\end{array}$ & 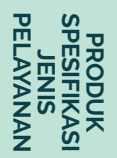 \\
\hline 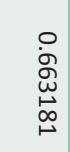 & $\begin{array}{l}\stackrel{0}{\sim} \\
\stackrel{\infty}{\infty} \\
\stackrel{\infty}{\omega} \\
\mapsto\end{array}$ & 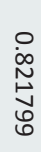 & $\begin{array}{l}\stackrel{\bullet}{\circ} \\
\dot{8} \\
\dot{8}\end{array}$ & $\begin{array}{l}\circ \\
\text { i } \\
\text { N } \\
\text { O } \\
\text { I }\end{array}$ & 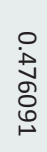 & $\begin{array}{l}0 \\
\infty \\
\infty \\
\infty \\
\text { مे } \\
\text { D }\end{array}$ & 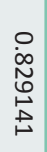 & 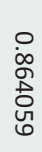 & 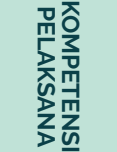 \\
\hline $\begin{array}{l}0 \\
\text { Oे } \\
\text { ஸे } \\
+\end{array}$ & 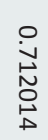 & $\begin{array}{l}\text { டे } \\
8 \\
8\end{array}$ & $\begin{array}{l}0 \\
0 \\
\stackrel{0}{*} \\
\stackrel{\bullet}{0}\end{array}$ & 옹 & $\begin{array}{l}\stackrel{0}{+} \\
\stackrel{+}{\infty} \\
\stackrel{\infty}{g}\end{array}$ & $\begin{array}{l}\stackrel{0}{\dot{\alpha}} \\
\underset{\omega}{\infty} \\
\stackrel{\infty}{0} \\
\stackrel{v}{v}\end{array}$ & $\begin{array}{l}0 \\
\dot{6} \\
\text { N } \\
\text { o } \\
\text { D }\end{array}$ & 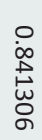 & 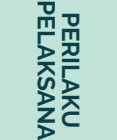 \\
\hline $\begin{array}{l}\text { ज़ } \\
\text { D } \\
\text { ज़ }\end{array}$ & $\begin{array}{l}\dot{\circ} \\
\dot{8} \\
\dot{0}\end{array}$ & 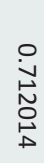 & $\begin{array}{l}\stackrel{ }{0} \\
\stackrel{\infty}{\infty} \\
\stackrel{\infty}{\omega}\end{array}$ & $\begin{array}{l}\text { ㅁ } \\
\text { ठ̀ } \\
\text { ू }\end{array}$ & \begin{tabular}{l}
0 \\
$\dot{E}$ \\
\multirow{U}{0}{} \\
0
\end{tabular} & $\begin{array}{l}0 \\
\dot{D} \\
\sim \\
\infty \\
0 \\
1\end{array}$ & $\begin{array}{l}0 \\
\text { ఫे } \\
\text { ठे } \\
\text { +ి }\end{array}$ & $\begin{array}{l}0 \\
\dot{\alpha} \\
0 \\
0 \\
\text { N } \\
\text { N }\end{array}$ & 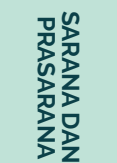 \\
\hline ষ் & 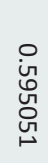 & 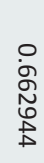 & $\begin{array}{l}\stackrel{0}{\dot{\sigma}} \\
\underset{\omega}{\infty} \\
\stackrel{\infty}{\mapsto}\end{array}$ & $\begin{array}{l}\text { O } \\
\text { N } \\
\text { Oे̆ } \\
\text { O }\end{array}$ & $\begin{array}{l}\stackrel{0}{\tilde{N}} \\
\underset{\sim}{\sim} \\
\stackrel{\infty}{\mapsto}\end{array}$ & $\begin{array}{l}0 \\
\text { in } \\
\infty \\
\infty \\
\infty \\
0\end{array}$ & 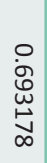 & $\begin{array}{l}\text { ㅇ } \\
\text { के } \\
\text { } \\
\text { ే̃ }\end{array}$ & 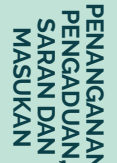 \\
\hline
\end{tabular}

\section{Pusat Penelitian dan Pengembangan}


Berdasarkan hasil analisis korelasi pada Tabel diatas, dapat diketahui hubungan antar unsur pelayanan yaitu:

1. Unsur Persyaratan

Berdasarkan korelasinya, hubungan paling kuat hingga paling rendah terhadap unsur persyaratan adalah unsur:
a. Produk Spesifikasi Jenis Pelayanan,
b. Kompetensi Pelaksana, Perilaku Pelaksana,
c. Waktu Pelayanan,
d. Prosedur,
e. Sarana dan Prasarana,
f. Penanganan Pengaduan,
g. Saran dan Masukan,
h. Biaya/Tarif.

2. Unsur Prosedur

Berdasarkan korelasinya, hubungan paling kuat hingga paling rendah terhadap unsur prosedur adalah unsur:
a. Produk Spesifikasi Jenis Pelayanan,
b. Waktu Pelayanan,
c. Kompetensi Pelaksana,
d. Persyaratan,
e. Perilaku Pelaksana,
f. Penanganan Pengaduan, Saran dan Masukan,
g. Sarana dan Prasarana,
h. Biaya/Tarif

3. Unsur Waktu Pelayanan

Berdasarkan korelasinya, hubungan paling kuat hingga paling rendah terhadap unsur waktu pelayanan adalah unsur:
a. Kompetensi Pelaksana,
b. Produk Spesifikasi Jenis Pelayanan,
c. Prosedur,
d. Persyaratan,
e. Sarana dan Prasarana,
f. Perilaku Pelaksana,
g. Biaya/Tarif,
h. Penanganan Pengaduan, Saran dan Masukan 
4. Unsur Biaya/Tarif

Berdasarkan korelasinya, hubungan paling kuat hingga paling rendah terhadap unsur biaya/tarif adalah unsur:
a. Waktu Pelayanan,
b. Produk Spesifikasi Jenis Pelayanan,
c. Prosedur,
d. Persyaratan,
e. Sarana dan Prasarana,
f. Kompetensi Pelaksana,
g. Perilaku Pelaksana,
h. Penanganan Pengaduan, Saran dan Masukan

5. Unsur Produk Spesifikasi Jenis Pelayanan

Berdasarkan korelasinya, hubungan paling kuat hingga paling rendah terhadap unsur Produk Spesifikasi Jenis Pelayanan adalah unsur:
a. Persyaratan,
b. Prosedur,
c. Waktu Pelayanan,
d. Kompetensi Pelaksana,
e. Perilaku Pelaksana,
f. Penanganan Pengaduan, Saran dan Masukan,
g. Sarana dan Prasarana,
h. Biaya/Tarif

6. Unsur Kompetensi Pelaksana

Berdasarkan korelasinya, hubungan paling kuat hingga paling rendah terhadap unsur Kompetensi Pelaksana adalah unsur :
a. Waktu Pelayanan,
b. Persyaratan,
c. Produk Spesifikasi Jenis Pelayanan,
d. Prosedur,
e. Perilaku Pelaksana,
f. Sarana dan Prasarana,
g. Penanganan Pengaduan, Saran dan Masukan,
h. Biaya/Tarif

7. Unsur Perilaku Pelaksana

Berdasarkan korelasinya, hubungan paling kuat hingga paling rendah terhadap unsur Perilaku Pelaksana adalah unsur:
a. Persyaratan,
b. Kompetensi Pelaksana,
c. Produk Spesifikasi Jenis Pelayanan,
d. Sarana dan Prasarana,
e. Prosedur,
f. Penanganan Pengaduan, Saran dan Masukan,
g. Waktu Pelayanan,
h. Biaya/Tarif

\section{Pusat Penelitian dan Pengembangan} Kementerian Agraria dan Tata Ruang/Badan Pertanahan Nasional 


\section{Unsur Sarana dan Prasarana}

Berdasarkan korelasinya, hubungan paling kuat hingga paling rendah terhadap unsur Sarana dan Prasarana adalah unsur:
a. Waktu Pelayanan,
b. Kompetensi Pelaksana,
c. Perilaku Pelaksana,
d. Produk Spesifikasi Jenis Pelayanan,
e. Persyaratan,
f. Prosedur,
g. Penanganan Pengaduan, Saran dan Masukan,
h. Biaya/Tarif

9. Unsur Penanganan Pengaduan, Saran dan Masukan

Berdasarkan korelasinya, hubungan paling kuat hingga paling rendah terhadap unsur Penanganan Pengaduan, Saran dan Masukan adalah unsur:
a. Produk Spesifikasi Jenis Pelayanan,
b. Prosedur,
c. Persyaratan,
d. Kompetensi Pelaksana,
e. Perilaku Pelaksana,
f. Sarana dan Prasarana,
g. Waktu Pelayanan,
h. Biaya/Tarif

Berdasarkan nilai SKM total (12 Provinsi sampel) diketahui bahwa penilaian terhadap unsurunsur yang diteliti adalah sebagaimana Tabel 4.2.

Tabel 4.2. Penilaian Unsur Pelayanan

\begin{tabular}{|c|l|c|c|}
\hline NO. & \multicolumn{1}{|c|}{ UNSUR PELAYANAN } & \multicolumn{2}{c|}{ NILAI RATA-RATA } \\
\hline U3 & Waktu Pelayanan & 2.825 & 70.62 \\
\hline U8 & Sarana dan Prasarana & 2.887 & 72.18 \\
\hline U2 & Prosedur & 3.053 & 76.33 \\
\hline U5 & Produk Spesifikasi Jenis Pelayanan & 3.080 & 77.00 \\
\hline U4 & Biaya/Tarif & 3.102 & 77.55 \\
\hline U6 & Kompetensi Pelaksana & 3.121 & 78.03 \\
\hline U1 & Persyaratan & 3.170 & 79.26 \\
\hline U7 & Perilaku Pelaksana & 3.209 & 80.23 \\
\hline U9 & Penanganan Pengaduan, Saran dan Masukan & 3.315 & 82.88 \\
\hline
\end{tabular}

Sumber: Olah Data, 2018

Pada Tabel 4.2 diketahui bahwa unsur-unsur pelayanan yang memiliki nilai terendah adalah

Waktu Pelayanan, Sarana dan Prasarana serta Prosedur. Ketiga unsur tersebut menjadi prioritas utama yang perlu diperbaiki dalam rangka peningkatan kepuasan masyarakat dalam 
pelayanan pertanahan. Perbaikan pada unsur Waktu Pelayanan, Sarana dan Prasarana serta Prosedur, hendaklah diutamakan pada unsur-unsur lain yang memiliki keterkaitan kuat dengan unsur-unsur tersebut sebagaimana telah diuraikan sebelumnya.

\subsection{Rencana Tindak Lanjut Perbaikan SKM}

Secara umum waktu layanan menjadi unsur yang paling banyak dikeluhkan empat tahun terakhir dalam survei kepuasan masyarakat sebab volume beban kerja yang ditanggung oleh masing-masing Kantor Pertanahan setiap tahun relatif bentambah signifikan. Pelayanan rutin yang ada dikantor melalui loket banyak ditambah program strategis yang diamanahkan ke kementerian ATR/BPN juga bertambah setiap tahun, sementara SDM yang ada jumlahnya relatif tetap. Kondisi seperti ini berakibat adanya tunggakan yang harus diselesaikan secara overtime. Layanan yang sifatnya pemeliharaan data, tanpa ada petugas turun ke lapangan tidak menjadi masalah. Persoalan baru muncul jika untuk penyelesaian layanan mewajibkan datangnya petugas ke lapangan. Implikasinya seluruh pegawai Kantor Pertanahan harus membagi prioritas mana yang akan diselesaikan terlebih dahulu layanan rutin atau program strategis seperti (PTSL).

Korelasi antara kualitas SDM dengan dengan waktu bisa direduksi dengan cara training dan evaluasi berkala utamanya menyangkut kemampuan pegawai untuk cermat dan teliti terhadap berkas yang masuk di loket. Masih banyak berkas yang kurang lengkap dan diterima di loket pendaftaran akibatnya layanan tersebut tidak dapat di proses. Keadaan ini dimungkinkan terjadi terkadang pegawai loket kurang menguasai alur prosedur layanan pertanahan tertentu disini peran penting training evaluasi dimana jika petugas loket yang seringkali di rolling maka peran kordinator loket menjadi vital selain harus bisa membaca situasi dan memberikan penjelasan ke masyarakat. Perlunya memberikan informasi layanan yang tepat dan akurat kepada masyarakat terkait persyaratan yang wajib dipenuhi, sehingga masyarakat tidak perlu beberapa kali datang untuk melengkapi persyaratan. Di kota-kota besar kendala ini teratasi dengan informasi digital masalahnya tidak semua kantor memiliki. Layanan Kantor Pertanahan memiliki beragam jenis layanan yang prosedur serta luarannya beraneka ragam apabila dimungkinkan perlu melakukan review terhadap prosedur yang sifatnya lebih memudahkan.

Tabel 4.3. Solusi Untuk Perbaikan Unsur Pelayanan

\begin{tabular}{|c|c|c|}
\hline UNSUR & KORELASI & SOLUSI \\
\hline \multirow[t]{4}{*}{ Waktu } & Kompetensi pelaksana & $\begin{array}{l}\text { Training dan evaluasi pegawai secara } \\
\text { kontineu }\end{array}$ \\
\hline & \multirow[t]{2}{*}{ Spesifikasi jenis layanan } & $\begin{array}{l}\text { Memberikan informasi yang lengkap dan } \\
\text { seutuhnya saat seleksi berkas }\end{array}$ \\
\hline & & Pembatasan layanan \\
\hline & Prosedur & Review SOP \\
\hline \multirow[t]{3}{*}{ Sarana dan prasarana } & waktu pelayanan & Peningkatan fasilitas kantor \\
\hline & Kompetensi pelaksana & Training dan evaluasi \\
\hline & Perilaku pelaksana & $\begin{array}{l}\text { Pakta integritas } \\
\text { System reward \& punishment }\end{array}$ \\
\hline \multirow[t]{3}{*}{ Prosedur } & Produk spesifikasi layanan & \multirow[t]{3}{*}{ Review SOP } \\
\hline & Waktu layanan & \\
\hline & Kompetensi layanan & \\
\hline
\end{tabular}


Berkaitan dengan tabel tersebut di atas, perlu dilakukan beberapa hal untuk memperbaiki nilai SKM dengan tindak lanjut perbaikan terhadap unsur pelayanan yang nilainya rendah melalui berbagai progam.

Tabel 4.4. Rencana Tindak Lanjut SKM

\begin{tabular}{|l|l|l|l|l|}
\hline NO. & PRIORITAS UNSUR & \multicolumn{1}{|c|}{ PROGRAM/KEGIATAN } & WAKTU & \multicolumn{1}{|c|}{ PENANGGUNG JAWAB } \\
\hline 1. & Waktu & $\begin{array}{l}\text { a.Penyempurnaan SOP } \\
\text { b.Diklat Pelayanan }\end{array}$ & 1 tahun & Biro Kepegawaian/Unit teknis \\
\hline 2. & Sarana dan Prasarana & Grand Design Sarpras & RPJM & Biro Perencanaan \\
\hline 3. & Prosedur & Penyempurnaan SOP & 1 tahun & Biro Kepegawaian/Unit Teknis \\
\hline
\end{tabular}





\subsection{KESIMPULAN}

Dari hasil pengolahan dan analisis data Survei Kepuasan Masyarakat Terhadap Pelayanan Pertanahan pada lokasi sampel yang teridiri dari 24 kabupaten/kota di 12 provinsi dapat diambil beberapa kesimpulan, diantaranya adalah:

1. Nilai Indeks Kepuasan Masyarakat Terhadap Pelayanan Pertanahan pada Kabupaten/Kota sampel diperoleh angka nasional sebesar 76,35 berarti terdapat peningkatan dari nilai tahun 2017 (sebesar 72,47), namun karena standar nilai berdasarkan Peraturan MENPAN RB berubah dan mengalami peningkatan maka nilai yang diperoleh Kementerian Agraria dan Tata Ruang/Badan Pertanahan Nasional pada tahun 2018 termasuk dalam kategori "kurang baik".

2. Unsur pelayanan yang mendapatkan nilai terendah adalah Waktu Pelayanan $(70,62)$, Sarana dan Prasarana $(72,18)$ serta Prosedur Pelayanan $(76,33)$. Sedangkan unsur tertinggi adalah Penanganan Pengaduan Saran dan Masukan $(82,88)$, Perilaku Pelaksana $(80,23)$, dan Persyaratan $(79,26)$;

3. Kualitas pelayanan antara Kantor Pertanahan berstatus kota dengan Kantor Pertanahan berstatus kabupaten cenderung tidak memiliki perbedaan yang signifikan. Nilai SKM Kantor Pertanahan di kota sebesar 71,99 sedangkan Kantor Pertanahan wilayah kabupaten memiliki nilai 72,61;

\subsection{SARAN}

1. Berkaitan dengan rendahnya unsur pelayanan waktu, maka perlu dihidupkan kembali tipologi kelas satuan kerja, tapi perlu perhitungan lebih jelas dan terarah menggunakan metode yang lebih ilmiah dan terukur dengan mempertimbangkan unsur pokok dan unsur penunjang sebagaimana diarahkan dalam Peraturan Menteri Negara Pendayagunaan Aparatur Negara Nomor 18 tahun 2018.

2. Dengan adanya tipologi kantor, maka dalam SOP diatur adanya perbedaan penyelesaian pekerjaan misalnya roya di kelas A ditetapkan lima hari, maka roya di kelas B dapat diberikan 3 hari dan untuk kelas $\mathrm{C}$ dapat diberikan dalam satu hari. 


\section{DAFTAR PUSTAKA}




\section{Peraturan Perundang-undangan}

Republik Indonesia. 2009. Undang-Undang Nomor 25 Tahun 2009 tentang Pelayanan Publik. Tambahan Lembaran Negara Republik Indonesia Tahun 2009 Nomor 112. Sekretariat Kabinet RI. Jakarta

Republik Indonesia. 2012. Peraturan Pemerintah Nomor 96 Tahun 2012 tentang Pelaksanaan Undang-Undang Nomor 25 Tahun 2009 tentang Pelayanan Publik. Tambahan Lembaran Negara Republik Indonesia Tahun 2012 Nomor 215. Sekretariat Kabinet RI. Jakarta.

Republik Indonesia, 2015. Peraturan Menteri Pendayagunaan Aparatur Negara dan Reformasi Birokrasi Nomor 1 Tahun 2015 tentang Pedoman Evaluasi Kinerja Penyelenggara Pelayanan Publik

Republik Indonesia. 2017. Peraturan Menteri Pendayagunaan Aparatur Negara dan Reformasi Birokrasi Nomor 14 Tahun 2017 tentang Pedoman Survei Kepuasan Masyarakat Terhadap Penyelenggaraan Pelayanan Publik. Berita Negara Republik Indonesia Tahun 2014 Nomor 616. Sekretariat Kabinet RI. Jakarta.

\section{Buku}

Abdul Mahsyar, Oktober,2011, Masalah Pelayanan Publik di Indonesia Dalam Perspektif Administrasi Publik.

Agus Pramusinto dan Erwan Agus Purwanto. 2009. Reformasi Birokrasi, Kepemimpinan dan Pelayanan Publik: Kajian Tentang Pelaksanaan Otonomi Daerah. Yogyakarta: Gava Media.

Barata, Atep, Adya, 2003, Dasar-Dasar Pelayanan Prima, PT. Elexmedia Computindo: Jakarta

Christoper Lovelock, Product Plus: How Product Service Competitive Advantage. 1988 New York : Mc Graw Hill

Dwiyanto, Agus. 2005. Mewujudkan Good Governance Melalui Pelayanan Publik. Yogyakarta: Gadjah Mada University Press.

Dwiyanto, Agus. 2011. Mengembalikan Kepercayaan Publik Melalui Reformasi Birokrasi. Jakarta: Gramedia Pustaka Utama.

Fandy Tjiptono, 2008, Service Management. Penerbit Andi. Yogjakarta

H.R. Riyadi Soeprapto, Heru Ribawanto, Iman Hanafi, 2000, Pengembangan Sumber Daya Aparatur Daerah di Era Reformasi Kasus Kabupaten Trenggalek, Jurnal Administrasi Negara, Vol. I

Juniarso Ridwan dan Achmad Sodik Sudrajat. 2009. Hukum Administrasi Negara dan Kebijakan Pelayanan Publik. Bandung: Nuansa.

\section{Pusat Penelitian dan Pengembangan}


Sedarmayanti. 2010. Manajemen Sumber Daya Manusia: Reformasi Birokrasi dan Manajemen Pegawai Negeri Sipil. Bandung: Refika Aditama.

Sinambela, dkk. 2006. Reformasi Pelayanan Publik: Teori, Kebijakan, dan Implementasi. Jakarta: Bumi Aksara.

Surjadi. 2009. Pengembangan Kinerja Pelayanan Publik. Bandung: Pengembangan Kinerja Pelayanan Publik.

Thoha, Miftah. 2008. Birokrasi Pemerintah Indonesia di Era Reformasi. Jakarta: Prenada Media Group. 



\section{LAMPIRAN}


Lampiran 1. Kuesioner Survei Kepuasan Masyarakat

\begin{tabular}{|c|c|c|c|}
\hline TANGGAL SURVEI: & & \multirow[t]{2}{*}{ JAM SURVEI } & \multirow{2}{*}{$\begin{array}{l}08.00-12.00 \\
13.00-17.00\end{array}$} \\
\hline & & & \\
\hline \multicolumn{4}{|c|}{ I. PROFIL } \\
\hline 1. Nomor Responden & \multicolumn{2}{|l|}{............. (Diisi oleh petugas) } & \\
\hline 2. Usia & \multicolumn{2}{|l|}{.............. Tahun } & \\
\hline 3. Jenis Kelamin & 1. Laki-laki & 2. Perempuan & \\
\hline 4. Pendidikan & $\begin{array}{l}\text { 1. SD Kebawah } \\
\text { 2. SMP } \\
\text { 3. SMA/SMK }\end{array}$ & $\begin{array}{l}\text { 4. D1-D3 } \\
\text { 5. S-1/D-IV } \\
\text { 6. S2-S3 }\end{array}$ & \\
\hline 5. Pekerjaan Utama & $\begin{array}{l}\text { 1. PNS/TNI/POLRI } \\
\text { 2. Pegawai BUMN/BUMD } \\
\text { 3. Wiraswasta/Usahawan } \\
\text { 4. Pegawai Swasta }\end{array}$ & $\begin{array}{l}\text { 5. Petani } \\
\text { 6. Pelajar/Mahasiswa } \\
\text { 7. Lainnya, sebutkan ... }\end{array}$ & \\
\hline $\begin{array}{l}\text { 6. Jenis Pelayanan yang } \\
\text { Saudara akses/urus } \\
\text { di Kantor Pertanahan } \\
\text { (BPN) }\end{array}$ & $\begin{array}{l}\text { 1. Pendaftaran Pertama Kal } \\
\text { 2. Peralihan Hak } \\
\text { 3. Pengecekan } \\
\text { 4. Roya } \\
\text { 5. Pendaftaran Tanah Sisten }\end{array}$ & natis Lengkap (PTSL) & \\
\hline
\end{tabular}

\section{PENDAPAT RESPONDEN TENTANG PELAYANAN}

(Lingkari kode huruf sesuai jawaban masyarakat/responden)

1. Bagaimana pendapat Saudara tentang 6. Bagaimana pendapat Saudara tentang kesesuaian persyaratan pelayanan pertanahan kompetensi/kemampuan petugas dalam dengan jenis pelayanan?
1) Tidak Sesuai.
2) Kurang Sesuai.
3) Sesuai.
4) Sangat Sesuai. pelayanan?
1) Tidak kompeten.
2) Kurang kompeten.
3) Kompeten.
4) Sangat kompeten.

2. Bagaimana pendapat Saudara tentang 7. Bagaimana perilaku petugas dalam kemudahan prosedur pelayanan pertanahan?
1) Tidak mudah.
2) Kurang mudah.
3) Mudah.
4) Sangat mudah.

memberikan pelayanan?
1) Tidak Sopan dan ramah.
2) Kurang Sopan dan ramah.
3) Sopan dan ramah.
4) Sangat Sopan dan ramah.

3. Bagaimana pendapat Saudara tentang kecepatan 8. Bagaimana pendapat Saudara tentang waktu dalam memberikan pelayanan?
1) Tidak cepat.
2) Kurang cepat.
3) Tepat.
4) Sangat cepat.
1) Buruk.
2) Cukup.
3) Baik.
4) Sangat Baik. kualitas sarana dan prasarana?

4. Bagaimana pendapat Saudara tentang kewajaran 9. Bagaimana pendapat Saudara tentang biaya/tarif petugas dalam pelayanan?
1) Sangat Mahal.
2) Cukup Mahal.
3) Murah.
4) Gratis.
1) Tidak ada.
2) Ada tapi tidak berfungsi.
3) Berfungsi kurang maksimal.
4) Dikelola dengan baik.

5. Bagaimana pendapat Saudara tentang Berikan saran dan masukan Anda terhadap kesesuaian produk pelayanan antara yang layanan yang sudah Anda gunakan:

tercantum dalam standar pelayanan dengan hasil yang diberikan?
1) Tidak sesuai.
2) Kurang sesuai.
3) Sesuai.
4) Sangat sesuai. 


\section{Lampiran 2. Kriteria Responden dan Penjelasan Kuesioner Survei Kepuasan Masyarakat}

A. Kriteria Responden

Masyarakat yang pernah mendapatkan layanan pertanahan melalui kegiatan rutin dan proyek strategis, baik pemohon langsung maupun kuasa.

B. Penjelasan Kuesioner

\begin{tabular}{|c|c|c|}
\hline KODE & PERTANYAAN & PENJELASAN \\
\hline \multirow[t]{6}{*}{ I. } & Nomor Responden & Nomor urut responden yang diisi oleh petugas survei \\
\hline & Umur & Umur Respoden \\
\hline & Jenis Kelamin & Jenis Kelamin Responden \\
\hline & Pendidikan & Pendidikan terkahir yang ditamatkan responden \\
\hline & Pekerjaan Utama & $\begin{array}{l}\text { Pekerjaan utama responden. Jika jawaban responden adalah } \\
\text { lainnya (7), maka wajib disebutkan nama pekerjaan lainnya } \\
\text { tersebut. }\end{array}$ \\
\hline & $\begin{array}{l}\text { Jenis Pelayanan yang } \\
\text { Saudara akses/urus di Kantor } \\
\text { Pertanahan (BPN) }\end{array}$ & $\begin{array}{l}\text { Jenis pelayanan yang sedang diakses atau diurus oleh } \\
\text { responden. Apabila pelayanan berasal dari program/inovasi } \\
\text { tertentu, maka perlu disebutkan (Diisi oleh petugas) }\end{array}$ \\
\hline \multirow[t]{10}{*}{ II. } & Persyaratan & $\begin{array}{l}\text { Kemudahan memenuhi persyaratan yang diberikan/ } \\
\text { diinformasikan Kantor Pertanahan dengan kenyataan yang } \\
\text { harus dipenuhi berdasarkan jenis layanan. }\end{array}$ \\
\hline & Sistem/Mekanisme/Prosedur & $\begin{array}{l}\text { Kemudahan untuk mengikuti tahapan/prosedur pelayanan } \\
\text { sesuai dengan SOPP (Standar Operasional Pelayanan } \\
\text { Pertanahan). }\end{array}$ \\
\hline & Waktu penyelesaian & $\begin{array}{l}\text { Ketepatan waktu untuk menyelesaikan pelayanan dari setiap } \\
\text { jenis layanan pertanahan. }\end{array}$ \\
\hline & Biaya/Tarif & $\begin{array}{l}\text { Kesesuaian biaya/tarif antara standar biaya pelayanan } \\
\text { pertanahan dengan kenyataan yang dibayarkan. } \\
\text { Kemampuan membayar biaya/tarif sesuai standar biaya } \\
\text { pelayanan pertanahan. }\end{array}$ \\
\hline & $\begin{array}{l}\text { Produk Spesifikasi Jenis } \\
\text { Pelayanan }\end{array}$ & $\begin{array}{l}\text { Kesesuaian antara jenis layanan pertanahan yang dimohon } \\
\text { dengan produk yang dihasilkan. }\end{array}$ \\
\hline & Kompetensi Pelaksana & $\begin{array}{l}\text { Kemampuan yang dimiliki oleh pelaksana meliputi } \\
\text { pengetahuan, keahlian, keterampilan, dan pengalaman. }\end{array}$ \\
\hline & Perilaku Pelaksana & Sikap petugas dalam memberikan pelayanan. \\
\hline & $\begin{array}{l}\text { Penanganan Pengaduan, Saran } \\
\text { dan Masukan }\end{array}$ & $\begin{array}{l}\text { Penanganan pengaduan, saran dan masukan, adalah tata cara } \\
\text { pelaksanaan penanganan pengaduan dan tindak lanjut. }\end{array}$ \\
\hline & Sarana dan Prasarana & $\begin{array}{l}\text { Sarana adalah segala sesuatu yang dapat dipakai sebagai alat } \\
\text { dalam mencapai maksud dan tujuan, misal computer, mesin } \\
\text { (benda bergerak). }\end{array}$ \\
\hline & & $\begin{array}{l}\text { Prasarana adalah segala sesuatu yang merupakan penunjang } \\
\text { utama terselenggaranya suatu proses, misal gedung (benda } \\
\text { tidak bergerak). }\end{array}$ \\
\hline Saran & Saran dan Masukan & $\begin{array}{l}\text { Responden memberikan saran dan masukan atas pelayanan } \\
\text { yang diterima. }\end{array}$ \\
\hline
\end{tabular}


Lampiran 3. Panduan Pelaksanan Indepth Interview

\begin{tabular}{|l|l|l|l|l|}
\hline \multirow{2}{*}{ NO. } & \multicolumn{2}{|c|}{$\begin{array}{c}\text { KUALITAS } \\
\text { RINCIAN PERTANYAAN }\end{array}$} & \multicolumn{2}{|c|}{ PELAYANAN } \\
\cline { 2 - 4 } & KETERANGAN \\
\hline
\end{tabular}

A. Persyaratan pelayanan adalah syarat yang harus dipenuhi dalam pengurusan suatu jenis pelayanan, baik persyaratan teknis maupun administrattif

\begin{tabular}{|l|l|}
\hline 1. & Persyaratan pelayanan terbuka dan jelas \\
\hline 2. & Persyaratan pelayanan mudah dipenuhi
\end{tabular}

B. Prosedur pelayanan adalah tata cara pelayanan yang dibakukan bagi penerima pelayanan

3. Informasi prosedur pelayanan terbuka

4. $\quad$ Alur prosedur pelayanan jelas

5. Prosedur pelayanan sederhana

6. Sistem dan prosedur pelayanan tidak memberikan peluang menimbulkan KKN

7. Petugas tidak menawarkan pelayanan untuk mempercepat proses di luar prosedur

8. Petugas tidak menerima tawaran untuk melakukan pelayanan di luar prosedur

9. Petugas tidak memberikan pelayanan di luar prosedur

10. Tidak terdapat praktik percaloan

C. Waktu pelayanan adalah jangka waktu yang diperlukan untuk menyelesaikan seluruh proses pelayanan

\begin{tabular}{|l|l|}
\hline 11. & Informasi waktu pelayanan jelas \\
\hline 12. & Pelaksanaan pelayanan tepat waktu \\
\hline 13. & $\begin{array}{l}\text { Informasi target waktu penyelesaian pelayanan } \\
\text { jelas }\end{array}$ \\
\hline 14. & $\begin{array}{l}\text { Penyelesaian pelayanan sesuai dengan targe } \\
\text { waktu }\end{array}$ \\
\hline
\end{tabular}

D. Biaya atau tarif adalah tarif yang dikenakan kepada penerima layanan dalam mengurus dan/atau memperoleh layanan

15. Biaya pelayanan jelas dan terbuka

16. Biaya yang dibayarkan sesuai dengan yang

17. Biaya pelayanan terjangkau

18. Biaya untuk mendapatkan pelayanan wajar

19. Petugas tidak menawarkan pelayanan untuk mempercepat proses diluar tarif resmi

20. Petugas tidak menerima tawaran untuk melakukan pelayanan di luar tarif resmi

21. Petugas tidak meminta imbalan berupa uang/ barang di luar tarif resmi

22. Petugas tidak menerima imbalan berupa uang/ barang di luar tarif resmi (gratifikasi)

23. Petugas tidak menuntut imbalan berupa uang/ jasa

\section{Pusat Penelitian dan Pengembangan}




\begin{tabular}{|c|c|c|c|c|c|}
\hline & \multirow{2}{*}{ No. } & \multirow{2}{*}{ RINCIAN PERTANYAAN } & \multicolumn{2}{|c|}{$\begin{array}{l}\text { KUALITAS } \\
\text { PELAYANAN }\end{array}$} & \multirow{2}{*}{ KETERANGAN } \\
\hline & & & YA & TIDAK & \\
\hline \multirow[t]{5}{*}{ E. } & \multicolumn{2}{|c|}{$\begin{array}{l}\text { Penanganan pengaduan, saran dan masukan adalah } \\
\text { mekanisme penanganan dan tindak lanjut terhadap } \\
\text { pengaduan, saran dan masukan }\end{array}$} & & & \\
\hline & 24. & $\begin{array}{l}\text { Sarana pengaduan/keluhan pelayanan publik } \\
\text { tersedia }\end{array}$ & & & \\
\hline & 25. & $\begin{array}{l}\text { Penanggung jawab/pengelolan penanganan } \\
\text { pengaduan/keluhan jelas }\end{array}$ & & & \\
\hline & 26. & Prosedur pengaduan/keluhan jelas & & & \\
\hline & 27. & $\begin{array}{l}\text { Kepastian tindak lanjut penanganan pengaduan/ } \\
\text { keluhan pelayanan publik jelas }\end{array}$ & & & \\
\hline \multirow[t]{3}{*}{$\mathrm{F}$. } & \multicolumn{2}{|c|}{$\begin{array}{l}\text { Kejelasan petugas/pelaksana adalah keberadaan dan } \\
\text { kepastian petugas yang memberikan pelayanan }\end{array}$} & & & \\
\hline & 28. & Keberadaan petugas pelayanan jelas & & & \\
\hline & 29. & $\begin{array}{l}\text { Jumlah petugas dengan konsumen seimbang } \\
\text { sehingga tidak menimbulkan antrian }\end{array}$ & & & \\
\hline \multirow[t]{4}{*}{ G. } & \multicolumn{2}{|c|}{$\begin{array}{l}\text { Kompetensi pelaksana adalah kemampuan yang harus } \\
\text { dimiliki oleh pelaksana meliputi pengetahuan, keahlian, } \\
\text { ketrampilan dan pengalaman }\end{array}$} & & & \\
\hline & 30. & Petugas pelayanan sigap dan cekatan & & & \\
\hline & 31. & $\begin{array}{l}\text { Petugas memiliki pengetahuan, keahlian, } \\
\text { ketrampilan dan pengalaman teknis yang } \\
\text { memadai }\end{array}$ & & & \\
\hline & 32. & $\begin{array}{l}\text { Petugas memiliki pengetahuan, keahlian, } \\
\text { ketrampilan dan pengalaman administrasi yang } \\
\text { memadai }\end{array}$ & & & \\
\hline \multirow[t]{5}{*}{$\mathrm{H}$. } & \multicolumn{2}{|c|}{$\begin{array}{l}\text { Perilaku pelaksana adalah sikap petugas dalam memberikan } \\
\text { pelayanan }\end{array}$} & & & \\
\hline & 33. & Sikap dan perilaku petugas pelayanan baik & & & \\
\hline & 34. & Petugas disiplin dalam menyelesaikan pelayanan & & & \\
\hline & 35. & $\begin{array}{l}\text { Petugas bertanggungjawab dalam memberikan } \\
\text { pelayanan }\end{array}$ & & & \\
\hline & 36. & Terdapat kesamaan perlakuan pelayanan & & & \\
\hline \multirow[t]{3}{*}{ I. } & \multicolumn{2}{|c|}{$\begin{array}{l}\text { Maklumat pelayanan adalah pernyataan kesanggupan dan } \\
\text { kewajiban penyelenggara untuk melaksanakan pelayanan }\end{array}$} & & & \\
\hline & 37. & Maklumat/janji pelayanan jelas & & & \\
\hline & 38. & $\begin{array}{l}\text { Pelaksanaan pelayanan sesuai dengan maklumat/ } \\
\text { janji pelayanan }\end{array}$ & & & \\
\hline \multirow[t]{6}{*}{ J. } & \multicolumn{2}{|c|}{$\begin{array}{l}\text { Kemanan dan kenyamanan saran dan prasarana pelayanan } \\
\text { yaitu terjaminnya tingkat keamanan dan kenyamanan } \\
\text { sarana dan prasarana pelayanan }\end{array}$} & & & \\
\hline & 39. & Lingkungan pelayanan aman & & & \\
\hline & 40. & $\begin{array}{l}\text { Sarana dan prasarana pelayanan bersih, rapi dan } \\
\text { nyaman }\end{array}$ & & & \\
\hline & 41. & $\begin{array}{l}\text { Sarana dan prasarana pelayanan lengkap dan } \\
\text { layak digunakan }\end{array}$ & & & \\
\hline & 42. & $\begin{array}{l}\text { Tersedia sarana untuk masyarakat berkebutuhan } \\
\text { khusus yang memadai }\end{array}$ & & & \\
\hline & 43. & $\begin{array}{l}\text { Mudah berkomunikasi dengan petugas melalui } \\
\text { tatap muka/telepon/faximile/email }\end{array}$ & & & \\
\hline
\end{tabular}




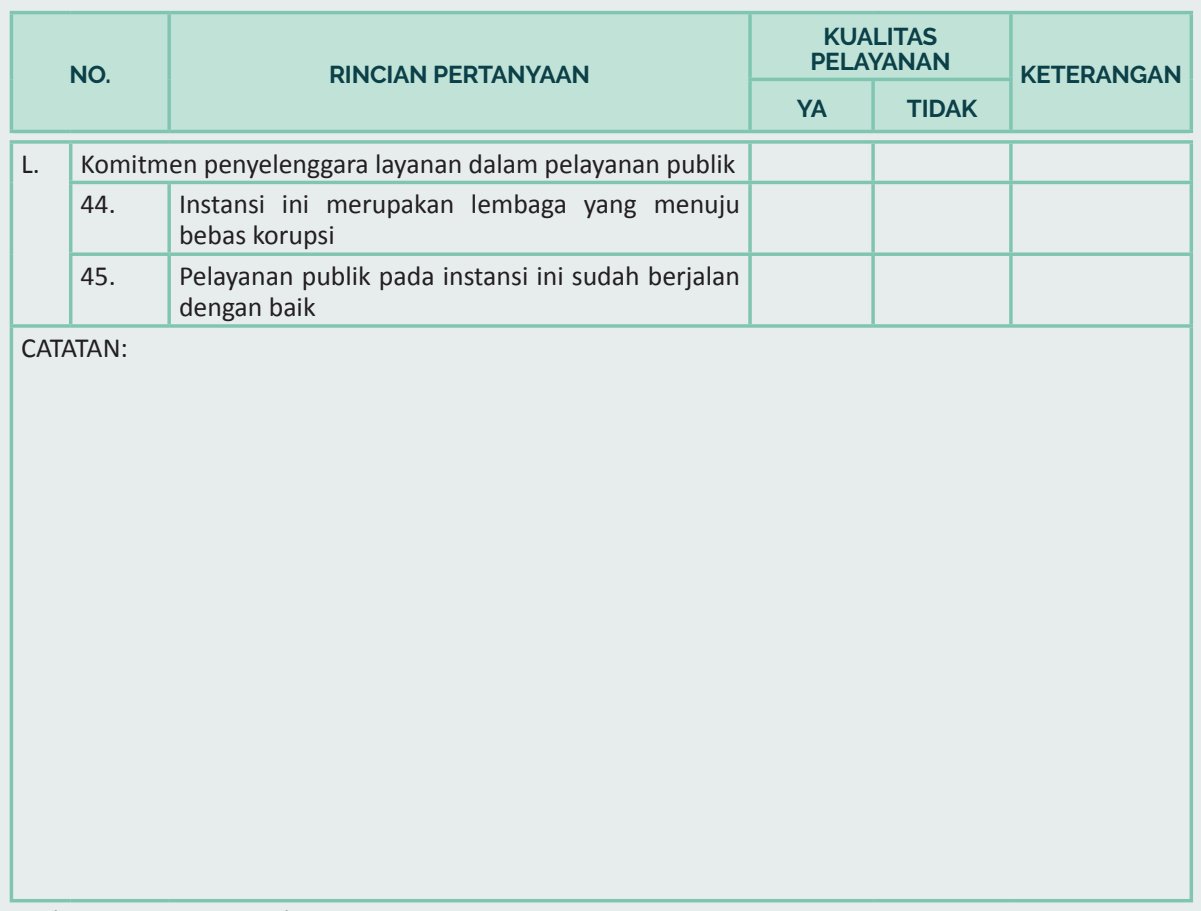

Sumber: Kementerian PAN dan RB

Keterangan: Beri tanda contreng $(V)$ pada jawaban ya atau tidak. 


\section{Lampiran 4. Panduan Observasi Kondisi Kantor}

KANTOR PERTANAHAN

\begin{tabular}{|c|c|c|c|c|}
\hline NO. & UNSUR PENDUKUNG PELAYANAN & YA & TIDAK & KETERANGAN \\
\hline \multicolumn{5}{|c|}{ A. FASILITAS LOKET PELAYANAN } \\
\hline 1. & Meja loket pelayanan & & & \\
\hline 2. & Ruang tunggu memadai & & & \\
\hline 3. & Meja untuk pengisian blangko atau formulir & & & \\
\hline \multirow[t]{5}{*}{4.} & Panel/papan informasi: & & & \\
\hline & a. Bagan alir & & & \\
\hline & b. Persyaratan & & & \\
\hline & c. Biaya/Tarif & & & \\
\hline & d. Jangka waktu layanan pertanahan & & & \\
\hline 5. & Nomor antrian manual/digital & & & \\
\hline \multicolumn{5}{|c|}{ B. KUALITAS LOKET PELAYANAN } \\
\hline \multicolumn{5}{|c|}{ KUALITAS PETUGAS LOKET } \\
\hline 6. & $\begin{array}{l}\text { Petugas loket/informasi dapat memberikan penjelasan } \\
\text { prosedur/syarat/administrasi pelayanan pertanahan: }\end{array}$ & & & \\
\hline \multirow[t]{3}{*}{7.} & Petugas loket memiliki sikap mental dan perilaku: & & & \\
\hline & a. Tanggap/Cekatan/Terampil & & & \\
\hline & b. Tidak mempersulit & & & \\
\hline 8. & $\begin{array}{l}\text { Petugas loket memiliki ketelitian dan kecermatan } \\
\text { mengenai Kelengkapan persyaratan/dokumen. }\end{array}$ & & & \\
\hline \multirow[t]{3}{*}{9.} & Pengalaman kerja petugas loket: & & & \\
\hline & a. Minimal masa kerja & & & \\
\hline & b. Pengalaman kerja & & & \\
\hline \multirow[t]{5}{*}{10.} & Penampilan petugas loket memiliki: & & & \\
\hline & a. Sopan & & & \\
\hline & b. Ramah & & & \\
\hline & c. Rapi & & & \\
\hline & d. bersih & & & \\
\hline \multirow[t]{5}{*}{11.} & Kedisiplinan petugas: & & & \\
\hline & a. Tepat waktu (kedatangan, istirahat dan pulang) & & & \\
\hline & b. Taat aturan (seragam) & & & \\
\hline & c. Konsisten & & & \\
\hline & d. Tanggung jawab & & & \\
\hline \multicolumn{5}{|c|}{ SARANA DAN PRASARANA } \\
\hline \multirow[t]{4}{*}{12.} & Standarisasi loket pelayanan & & & \\
\hline & a. Terletak di lokasi paling depan ruang Kantor & & & \\
\hline & b. Mudah dikenal oleh masyarakat & & & \\
\hline & $\begin{array}{l}\text { c. Minimal tersedia loket yang melayani informasi, } \\
\text { administrasi, pengaduan dan keuangan baik terpisah } \\
\text { atau digabung }\end{array}$ & & & \\
\hline
\end{tabular}




\begin{tabular}{|c|c|c|c|c|}
\hline NO. & UNSUR PENDUKUNG PELAYANAN & YA & TIDAK & KETERANGAN \\
\hline \multirow[t]{6}{*}{13.} & Standarisasi peralatan pelayanan & & & \\
\hline & $\begin{array}{l}\text { a. Pemanfaatan peralatan Teknologi Informasi: } \\
\text { komputerisasi, alkomlek, barcode reader, dan } \\
\text { lain-lain }\end{array}$ & & & \\
\hline & b. Penyimpan arsip : brankas, almari, filling cabinet & & & \\
\hline & c. Perlengkapan keamanan (pemadam kebakaran) & & & \\
\hline & d. Fasilitas P3K & & & \\
\hline & e. Media/kotak pengaduan & & & \\
\hline \multicolumn{5}{|c|}{ PENINGKATAN PROSEDUR } \\
\hline \multirow[t]{5}{*}{14.} & Jaminan kelancaran proses & & & \\
\hline & a. Ketepatan waktu pelayanan & & & \\
\hline & b. Kesiapan petugas pelayan setiap saat (jam kerja) & & & \\
\hline & c. Kesiapan fasilitas pelayanan & & & \\
\hline & d. Tertib urutan pelayanan (First in first out) & & & \\
\hline \multirow[t]{5}{*}{15.} & Kejelasan petunjuk prosedur pelayanan & & & \\
\hline & $\begin{array}{l}\text { a. Ketaatan pada Standar Pelayanan dan Pengaturan } \\
\text { Pertanahan }\end{array}$ & & & \\
\hline & $\begin{array}{l}\text { b. Pemasangan panel informasi, mudah dibaca dan } \\
\text { dipahami }\end{array}$ & & & \\
\hline & c. Kemampuan menerangkan oleh petugas & & & \\
\hline & d. Tersedianya brosur, leaflet di loket pelayanan & & & \\
\hline \multirow[t]{4}{*}{16.} & Efektifitas Monitoring (petugas loket) & & & \\
\hline & a. Inspeksi mendadak & & & \\
\hline & b. Pemanfaatan CCTV & & & \\
\hline & c. Sistem pelaporan (Laporan Monitoring) & & & \\
\hline \multirow[t]{4}{*}{17.} & Evaluasi & & & \\
\hline & $\begin{array}{l}\text { a. Koreksi setiap kesalahan / penyimpangan (rapat } \\
\text { koordinasi, apel pagi dsb) }\end{array}$ & & & \\
\hline & b. Sanksi pelanggaran tugas: teguran dan hukuman & & & \\
\hline & c. Inovasi/terobosan untuk peningkatan & & & \\
\hline
\end{tabular}

Sumber: Diolah dari PerKaBPN No. 3 Tahun 2010

\section{Pusat Penelitian dan Pengembangan}


Lampiran 5. Dokumentasi Pelayanan di Lokasi Sampel

Kantor Pertanahan Kota Samarinda

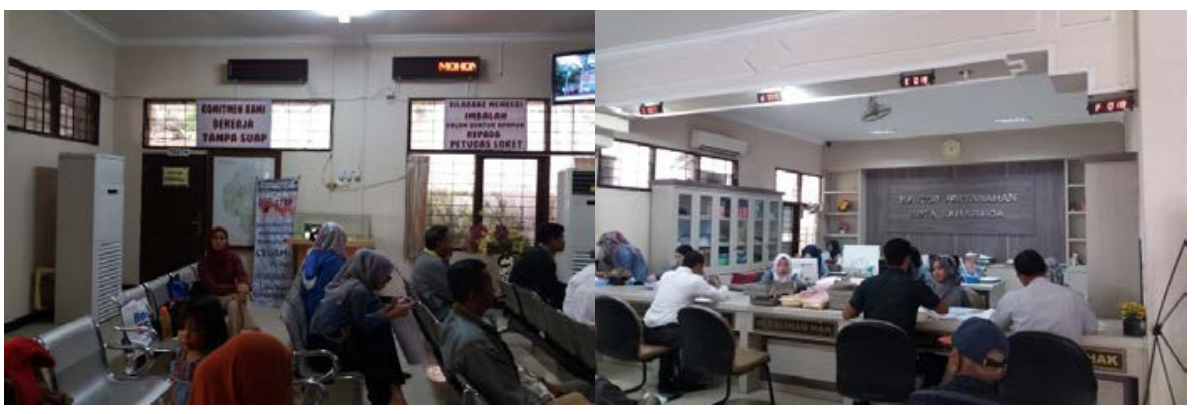

Kantor Pertanahan Kabupaten Kutai Kartanegara

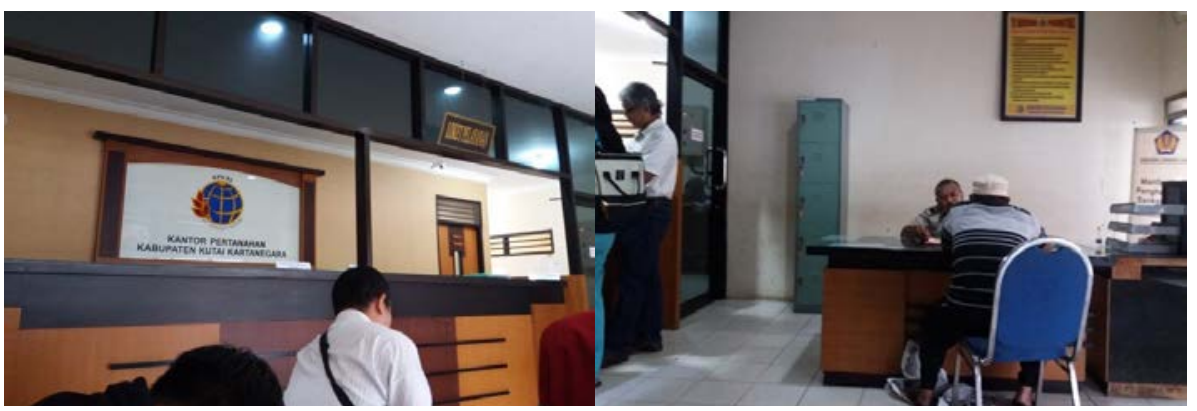

Kantor Pertanahan Kota Tanjung Pinang

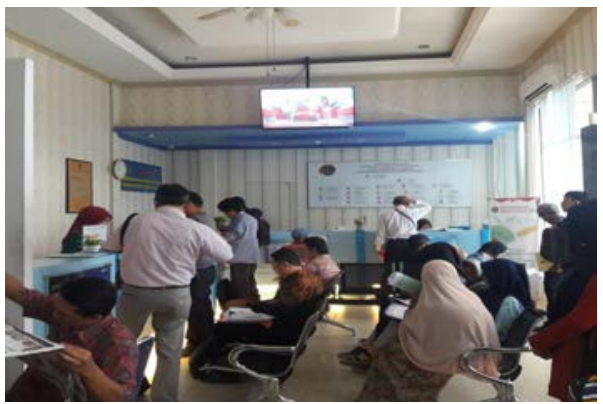

Kantor Pertanahan Kabupaten Bintan

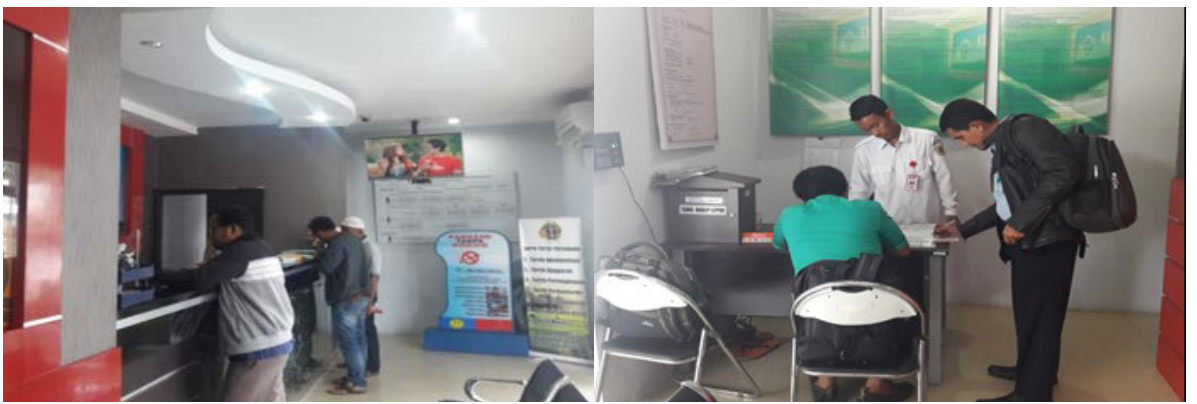




\section{Kantor Pertanahan Kota Yogyakarta}

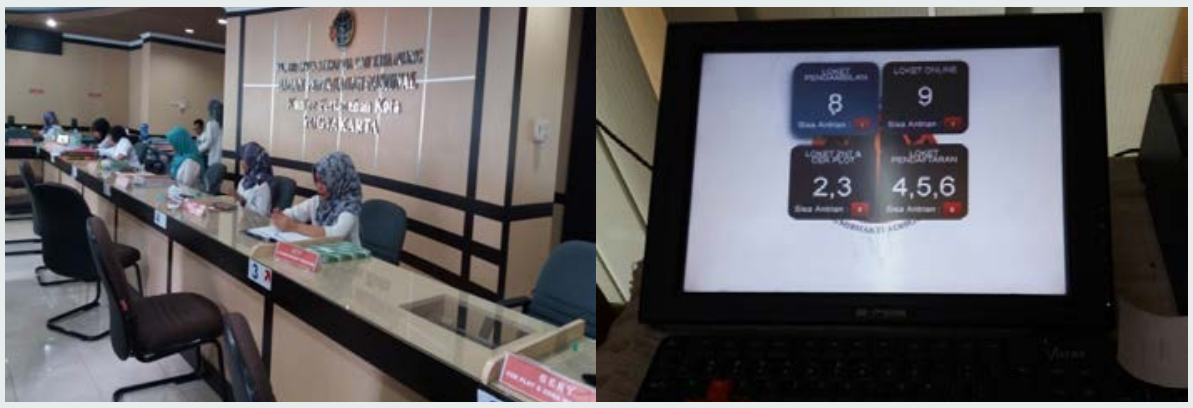

Kantor Pertanahan Kabupaten Sleman

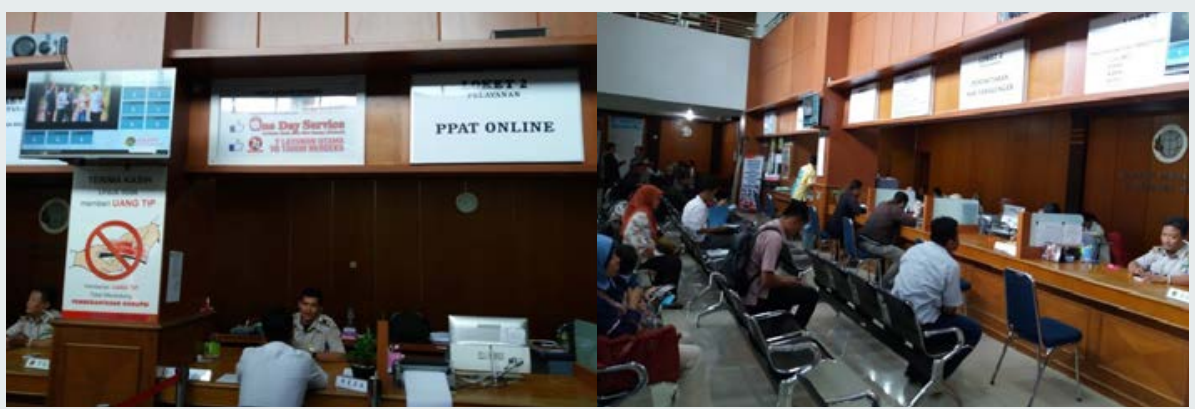

Kantor Pertanahan Kota Surabaya I

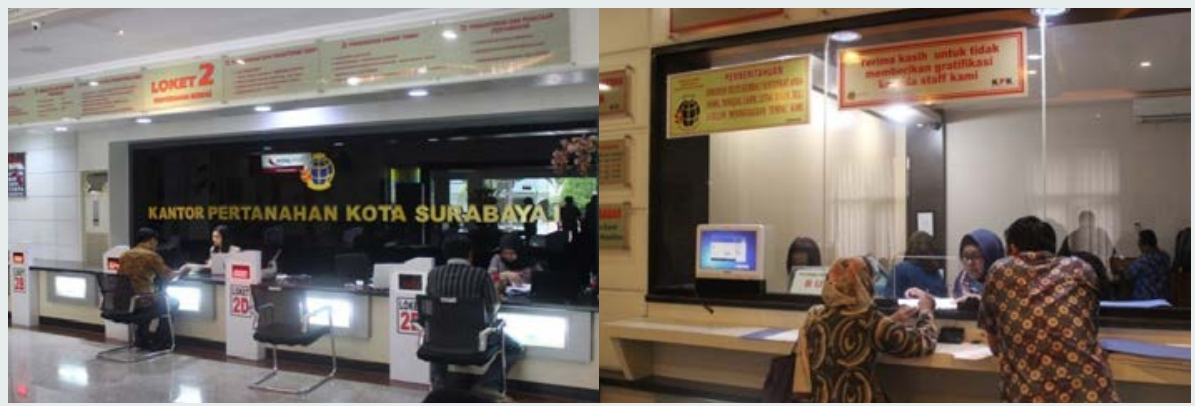

\section{Kantor Pertanahan Kabupaten Sidoarjo}

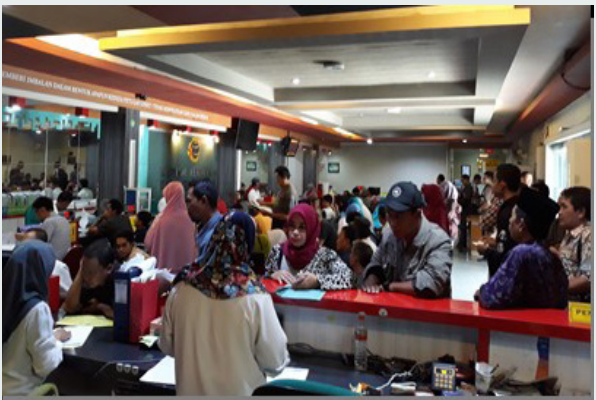


Kantor Pertanahan Kabupaten Banjar

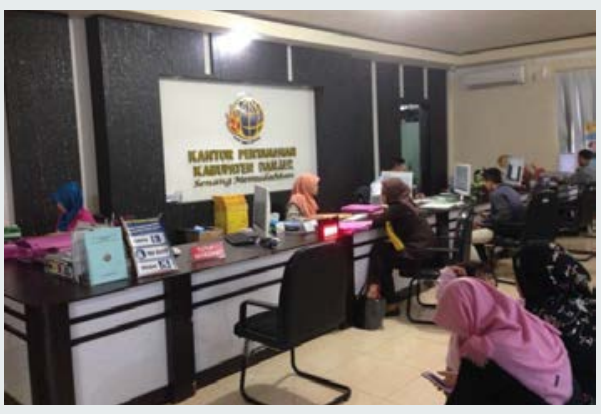

Kantor Pertanahan Kota Banjarmasin

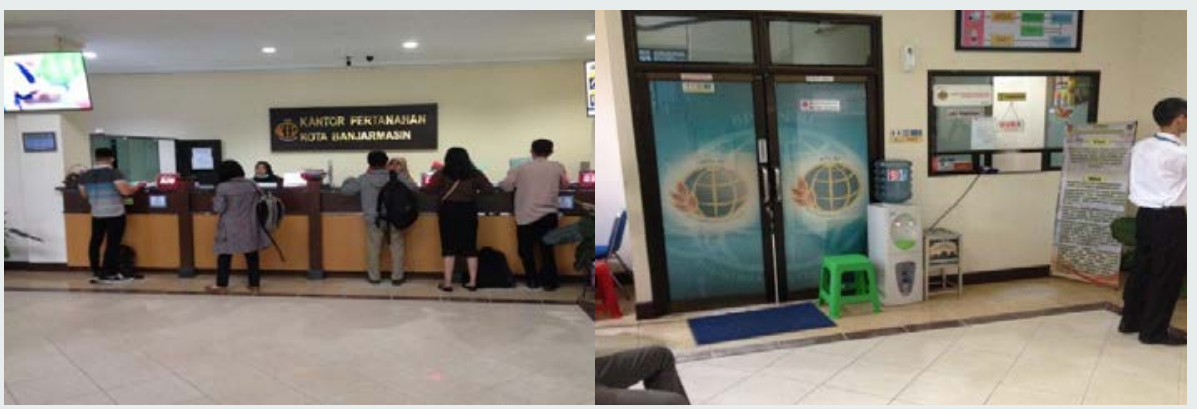

Kantor Pertanahan Kabupaten Konawe Selatan

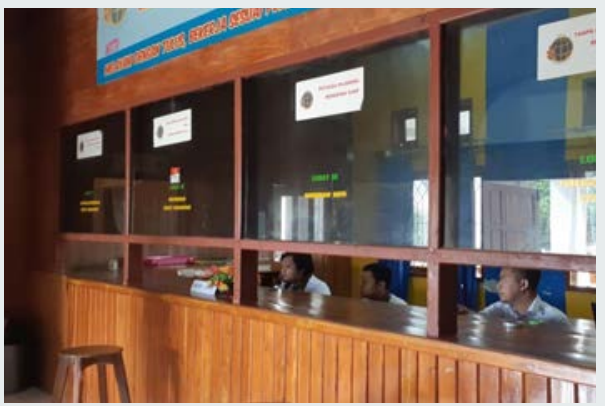

Kantor Pertanahan Kota Kendari

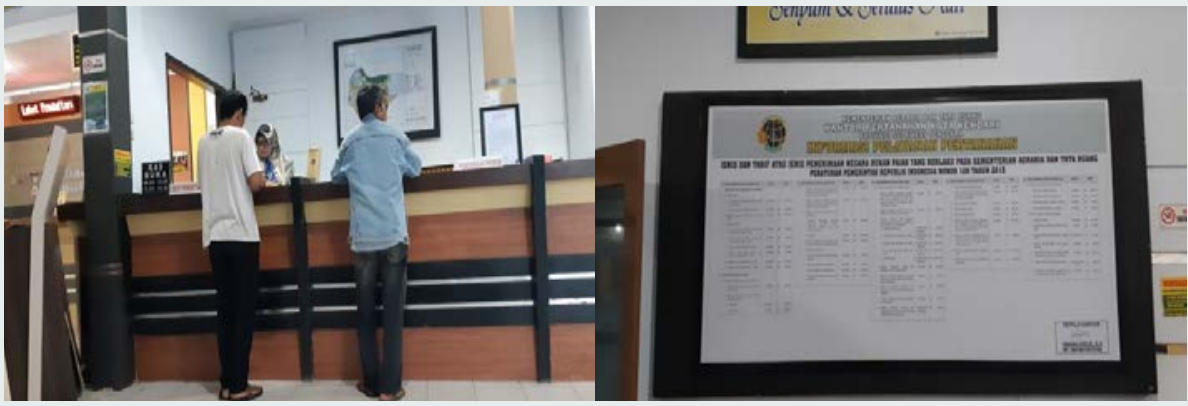




\section{Kantor Pertanahan Jakarta Utara}

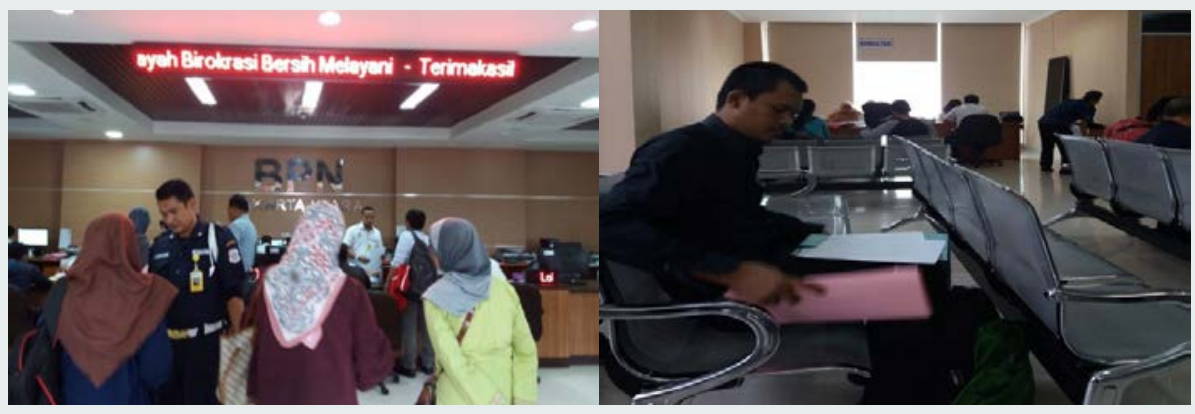

\section{Kantor Pertanahan Jakarta Pusat}

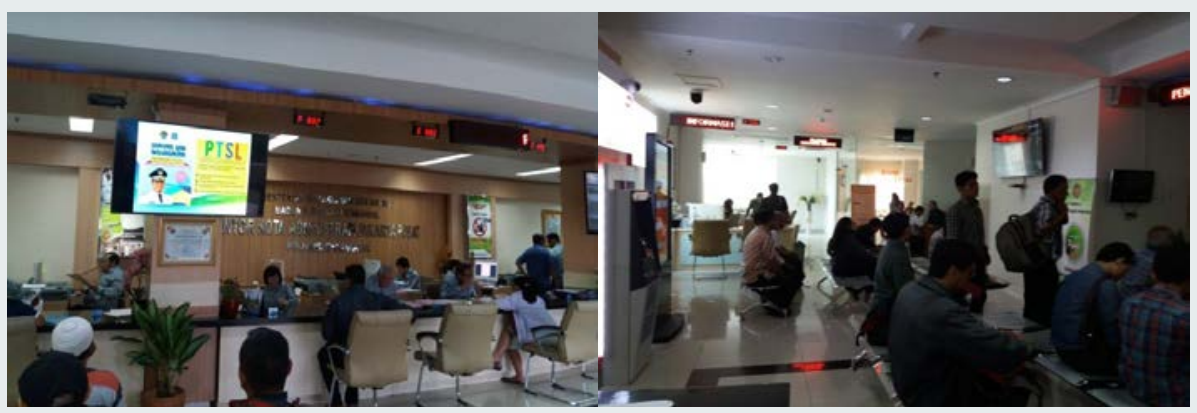

Kantor Pertanahan Kabupaten Gorontalo

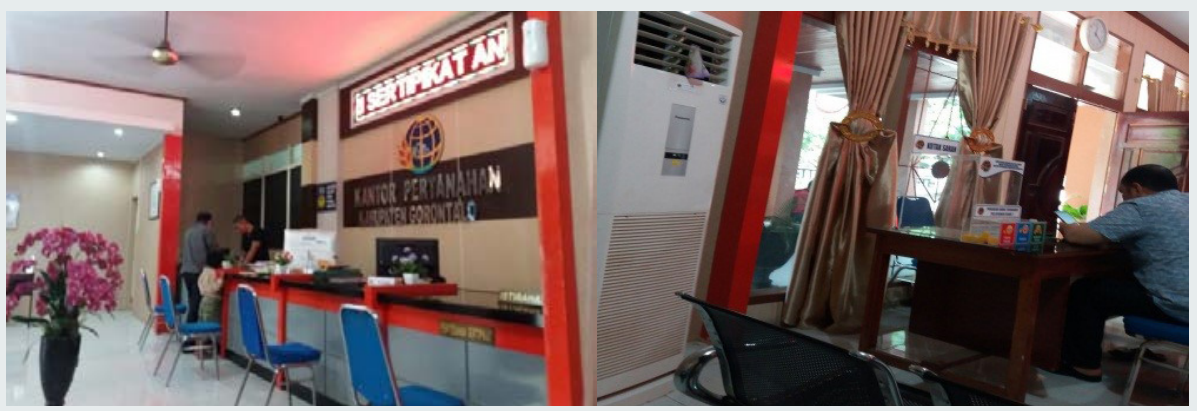

\section{Kantor Pertanahan Kota Gorontalo}
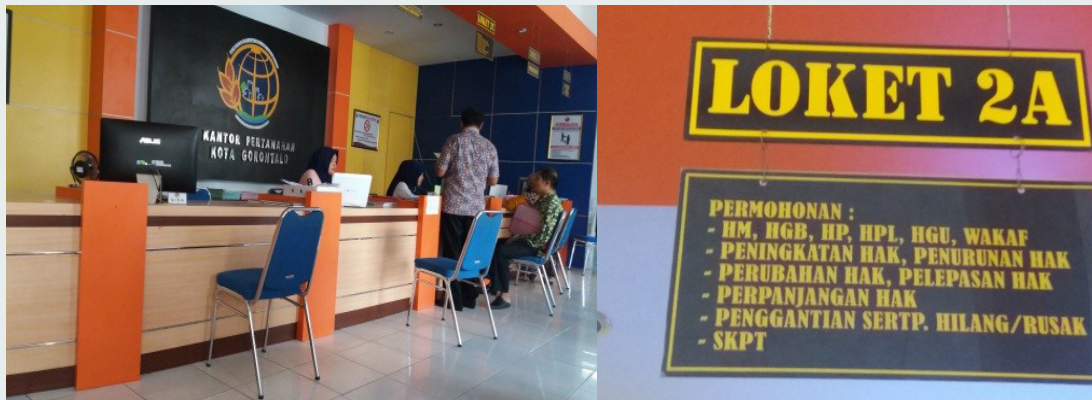

PERMOHONAN :

- HM, ICB, IIP, HPL, HCU, WAKAF

- PENINGKaTAN HAR, PENuRUNAN mak

- PERUBAHAN HAK, PELEASAN HIK

- PERpandangan hík

- PENGGantian SeRtr. Hitang/RUSAR

SKPT 


\section{Kantor Pertanahan Kota Ternate}

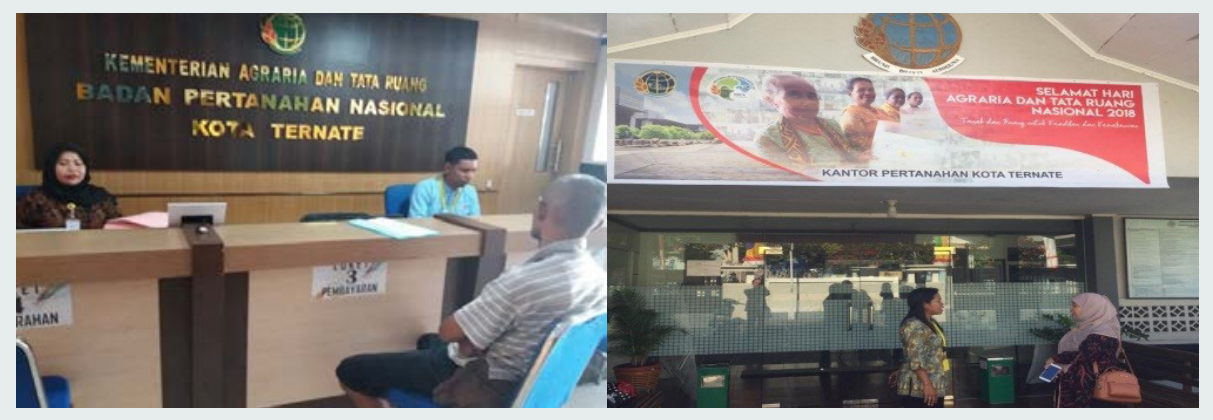


Pusat Penelitian dan Pengembangan Kementerian Agraria dan Tata Ruang/Badan Pertanahan Nasional 
ISBN 978-979-10เ9-เ6-3

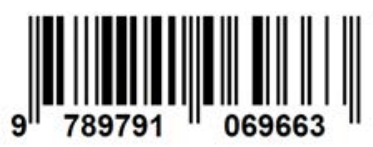

